DANIELA FRANCO DA SILVA

Avaliação da função do óxido nítrico na capacitação do espermatozoide equino criopreservado 
DANIELA FRANCO DA SILVA

\section{Avaliação da função do óxido nítrico na capacitação do espermatozoide equino criopreservado}

Dissertação apresentada ao Programa de PósGraduação em Reprodução Animal da Faculdade de Medicina Veterinária e Zootecnia da Universidade de São Paulo para a obtenção do título de Mestre em Ciências.

Departamento:

Reprodução Animal

Área de Concentração:

Reprodução Animal

Orientador: Prof. Dr. Rubens Paes de Arruda

Pirassununga 
Autorizo a reprodução parcial ou total desta obra, para fins acadêmicos, desde que citada a fonte.

DADOS INTERNACIONAIS DE CATALOGAÇÃO-NA-PUBLICAÇÃO

(Biblioteca Virginie Buff D’Ápice da Faculdade de Medicina Veterinária e Zootecnia da Universidade de São Paulo)

T.2772 Franco-Silva, Daniela

FMVZ Avaliação da função do óxido nítrico na capacitação do espermatozoide equino criopreservado / Daniela Franco da Silva. -- 2013.

$116 \mathrm{f}$ : : il.

Dissertação (Mestrado) - Universidade de São Paulo. Faculdade de Medicina Veterinária e Zootecnia. Departamento de Reprodução Animal, Pirassununga, 2013.

Programa de Pós-Graduação: Reprodução Animal.

Área de concentração: Reprodução Animal.

Orientador: Prof. Dr. Rubens Paes de Arruda.

1. Espermatozoide. 2. Capacitação. 3. Óxido Nitrico. 4. L-arginina. 5. L-NAME. Azul de metileno. I. Título. 


\title{
CERTIFICADO
}

\author{
UNIVERSIDADE DE SÃO PAULO
}

FACULDADE DE MEDICINA VETERINÁRIA E ZOOTECNIA

\section{Comissão de Ética no uso de animais}

\section{CERTIFICADO}

Certificamos que o Projeto intitulado "Avaliação da função do óxido nítrico na capacitação do espermatozóide equino criopreservado pelas análises por citometria de fluxo e computadorizada da motilidade", protocolado sob o $\mathrm{n}^{\circ}$ 1906/2010, utilizando 06 (seis) cavalos, sob a responsabilidade do Prof. Dr. Rubens Paes de Arruda, está de acordo com os princípios éticos de experimentação animal da "Comissão de Ética no uso de animais" da Faculdade de Medicina Veterinária e Zootecnia da Universidade de São Paulo e foi aprovado em reunião de 26/05/2010.

We certify that the Research "Evaluation of nitric oxide in the capacitation of criopreserved equine sperm by flow cytometry and computerized motility analyses", protocol number 1906/2010, utilizing 06 (six) horses, under the responsibility Prof. Dr. Rubens Paes de Arruda, agree with Ethical Principles in Animal Research adopted by "Ethic Committee in the use of animals" of the School of Veterinary Medicine and Animal Science of University of São Paulo and was approved in the meeting of day 05/26/2010.

São Paulo, 27 de maio de 2010

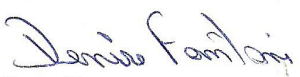

Profa. Dra. Denise Tabacchi Fantoni

Presidente 


\section{FOLHA DE AVALIAÇÃO}

Nome: Franco-Silva, Daniela

Título: Avaliação da função do óxido nítrico na capacitação do espermatozoide equino criopreservado

Dissertação apresentada ao Programa de Pós

Graduação em Reprodução Animal da Faculdade de Medicina Veterinária e Zootecnia da Universidade de São Paulo para a obtenção do título de Mestre em Ciências

Data:

Banca Examinadora

Prof. Dr.

Instituição

Julgamento

Prof. Dr.

Instituição

Julgamento

Prof. Dr.

Instituição

Julgamento 
"Bendito seja o QDeus e OPai de nosso Qhenhor Tesus Gristo, o OPai das misericórdias e QDeus de toda a consolasão, que nos consola em toda a nossa tribulasãa, para que também passamos consolar os que estiverem em alguma tribulasão, pela consolasãa com que nós mesmos somos consolados por QDeus"

2 Gorintios 1,3.4 
Dedico esta obra:

Alos meus pais Antonio Estevan da Silva (in memoriam) e Neuzina Franco da Silva.

Sou feliz por ter tido um pai tão maravilhoso, responsável, presente, dedicado, amoroso e que sempre acreditou e eu iria alcançar meus objetivos.

Muito obrigada pai! 


\section{Ao professor Rubens Paes de Arruda.}

Agradeço sinceramente por ter tido a oportunidade de ser orientada deste grande profissional da medicina veterinária. Um homem de caráter integro, ético, exímio educador, crítico em suas orientações, sempre visando nosso melhor...somente o nosso melhor. Às vezes um tanto austero com seus orientados, mas sei que esta é uma forma de nos educar como profissionais visando sempre, que no futuro, sejamos reconhecidos pela nosssa ética e profissionalismo no trabalho. Não tenho palavras que caibam nesta folha para descrever o quanto sou grata pela confiança que depositou em mim. Mesmo sem saber como sou, sem saber quais eram os meus defeitos e qualidades me honrou com seu aceite ao mestrado. Aprendi, no decorrer destes anos, que a pesquisa para ter impacto cietífico deve ser produzida com muita ética, amor a profissão e sem inverdades. Que o bom profissional não é aquele que trabalha somente em laboratório e com apenas uma espécie, mas sim, aquele que tem excelência a campo, laboratório e que tem conhecimento amplo da carreira que escolheu.

Hoje, avalio o quanto amadureci com seus ensinamentos aprendi a ser disciplinada, organizada, sempre hesitar e agir com cautela no trabalho objetivando a ausência de erros, a pensar antes de falar, enfim, adquiri postura profissional que somente quem passou pela sua orientação pode explicar. Na verdade posso afirmar que fui muito bem doutrinada. Termino o mestrado infindavelmente grata. Levarei os seus conselhos no meu coração, para toda a minha vida, não somente profissional, mas também pessoal. Espero sempre contar com sua ajuda e seus conselhos, grande amigo Rubens. 


\section{AGRADECIMENTOS}

À Deus, meu conforto, melhor amigo, confidente e protetor.

Ao Departamento de Reprodução Animal, pela oportunidade de fazer parte desta intituição de tanta excelência na pesquisa brasileira e internacional.

À CAPES e a FAPESP, pelo apoio financeiro durante o mestrado e auxílio para realização desta obra.

Ao professor Dr. André Furugen César de Andrade, por sua amizade, momentos de descontração e principalmente profissionalismo. Seu auxïlio e colaboração durante todo o período experimental foram fundamentais para a realização desta obra. Foi um grande aprendizado para mim.

Ao professor Dr. Flávio Meireles, por disponibilizar espaço físico fundamental para realização de nossas pesquisas.

Ao professor Dr. Heidge Fukumaso, pela colaboração e disponibilização da infraestrutura de seu laboratório freezer e refrigerador para o armazenamento das sondas.

À Fabiana Fernandes Bressan (Martini), por ser tão receptiva e nunca negar auxîlio em subtrair dūvidas sobre citometria.

À professora Dr. Eneiva Carla Carvalho Celeghini, pela amizade, educação e por sempre estar acessivel a qualquer momento.

À técnica Silvia Seraphin, pela paciência, amizade e por ter disponibilizado seu tempo para me ensinar a técnica de western blotting.

Aos professores do Departamento de Reprodução Animal: Anneliese de Souza Traldi, Camila Infantosi Vannucchi, Clair Motos de Oliveira, Claudia Barbosa Fernandes, Claudio Alvarenga de Oliveira, Ed Hoffmann Madureira, José Antonio Visintin, Marcelo Alcindo de Barros Vaz Guimarães, Mario Binelli, Mayra Elena Ortiz D'Avila Assumpção, Pietro Sampaio Baruselli, Renato Campanarut Barnabe, Ricardo José Garcia Pereira, Valquiria Hyppolito Barnabe pela aprazivel convivência.

Ao grupo do Laboratório de Biotécnologia do Sêmen e Andrologia-LBSA: Fernanda Jordão Affonso (BU) por ser tão prestativa e pela sua grande amizade, Maria 
Augusta Alonso (Guta) por sua amizade e por sempre estar disposta a ajudar em toda e qualquer situação e Renata Lançoni (Rê) por ser sempre tão amiga e gentil e Mariana de Paula Rodrigues (Mari) por ser tão amiga. Agradeço em especial aos meus grandes amigos, irmãos e companheiros de mestrado, Kleber Menegon Lemes (Ken) e Henrique Fulaneti Carvalho (İndio) que sempre estiveram dispostos a ajudar em todo momento, tendo paciência para ouvir minhas lamúrias dando sempre uma palavra de estímulo. Acredito que nossa amizade será eterna e sempre estaremos juntos mesmos que distantes. Agradeço também ao novo pós-doc do LBSA, Ticiano Guimarães Leite (Tici), que sem dúvida nenhuma é meu amigo, companheiro e grande parceiro para todos os momentos. Somos mais dos parceiros somos irmãos de verdade. Muito obrigada por ter sido meu braço direito neste momento tão tenso da minha vida.

Aos amigos irmãos da casa do VRA por todos os momentos de alegria e diversão, pelas longas conversas (principalmente aquelas onde ninguém entende ninguém), pelos desentendimentos e entendimentos, pela amizade, pelas chatices sentirei muita falta de todos vocês: Moana Rodrigues França (Mohand), Shirley Andrea Flores (Shirrrlei), Maira Bianchi Rodrigues Alves (Doce), Ticiano Leite (Tici), Kleber Menegon Lemes (Klebão), Henrique Fulaneti Carvalho (Índio), Roney Ramos (Nino), Thiago Santin (Arroiz) e Milton Maturana (Miltão). Agradeço em especial a minha grande amiga Moana Rodrigues França (Mohand), somos confidentes, irmãs e parceiras até debaixo dàgua.

Aos amigos, pós-graduandos, pós-doc, ex-ICs e estágiarios do VRA-Pirassununga pela convivência agradável: Gisele Mouro Ravagnani (Gi) por ser tão minha amiga, Leonardo Batissaco (Bati) pela amizade e pelas risadas, Milena Oliveira (Mi), Julianne Naves (Jú Mega), Gabriela Fonseca, Saara Scolari, Estela Rose Araújo (Estelinha), Everton Lopes (Louco Abreu), Roberta Harue, Bruna Oliveira, Fernando Mesquita, Guilherme Pugliese, Thainá Gardés, Rafaela Cardoso e Gabriel De Carli (Mascote do LBSA). 
Aos amigos e pós-graduandos do Departamento de Nutrição e Produção Animal (VNP)-USP, pela grande amizade Ana Paula Araújo, Maurício Furlan Martins (Xibungo) e Alejandro Vargas Velăsquez (Alejo).

À Prefeitura do Campus de Pirassununga, por disponibilizar os garanhões.

Aos funcionários Márcio Donizete De Carli, José Maria Bernarde e João Carlos Pinto de Campus, por terem sido tão meus amigos durante todos esses anos, pela confiança e peculiaridade de seus serviços estando sempre disponíveis em ajudar independente do horārio e do dia.

Aos ex-funcionários da cavalariça Maicon Gabriel Alves Godoy e Valdir da Silva pela amizade e por estarem sempre dispostos a colaborar conduzindo e contendo os garanhões para a colheita de sêmen.

Ao secretário do Departemento de Reprodução Animal VRA-Pirassununga Clayton Domingues Costa, por sempre ser tão gentil, educado e eficaz em seu trabalho. Agradeço pela sua amizade e por sempre estar disposto a me fornecer auxílio.

À secretâria da Pós-graduação do Departemento de Reprodução Animal Harumi Shiraishi, pela eficiêcia e honestidade em seu trabalho estando sempre acessivel quando necessário.

À Elza Faquim por sempre estar disposta a nos ajudar.

As funcionárias da limpeza Elaine Cristina Pereira e Alexandra Cristina Fabiano de Oliveira, pela amizade e por sempre deixar o nosso departamente impecável.

Agradeço a todos que de uma forma ou de outra estiveram ao meu lado, torcendo por mim, me aconselhando, me ouvindo, querendo ver sempre o meu melhor, então, termino com um poema de Machado de Assis que diz:

Abençoados os que possuem amigos, os que os têm sem pedir. Porque amigo não se pede, não se compra, nem se vende. Amigos a gente sente!

Benditos os que sofrem por amigos, os que falam com o olhar. Porque amigo não se cala, não questiona, nem se rende. Amigo a gente entende! 
Benditos os que guardam amigos, os que entregam o ombro pra chorar. Porque amigo sofre e chora. Amigo não tem hora pra consolar!

Benditos sejam os amigos que acreditam na tua verdade ou te apontam a realidade. Porque amigo é a direção. Amigo é a base quando falta o chão!

Benditos sejam todos os amigos de raízes, verdadeiros. Porque amigos são herdeiros da real sagacidade. Ter amigos é a melhor cumplicidade!

Há pessoas que choram por saber que as rosas têm espinhos, Há outras que sorriem por saber que os espinhos têm rosas!

Obrigada a todos! 


\section{RESUMO}

FRANCO-SILVA, D. Avaliação da função do óxido nítrico na capacitação do espermatozoide equino criopreservado. [Evaluation of the role of nitric oxide in capacitation of cryopreserved equine spermatozoa by flow cytometry and computerized sperm motility (CASA) analyses]. 2013. 116f. Dissertação (Mestrado em Ciências) Faculdade de Medicina Veterinária e Zootecnia, Universidade de São Paulo, Pirassununga, 2013

A capacitação é um pré-requisito fisiológico importante para que a célula espermática fertilize o oócito. O óxido nítrico (NO) é sintetizado in vivo durante a conversão da Larginina em L-citrulina por reações oxidativas catalisadas pela enzima óxido nítrico sintase (NOS) desempenhando um papel importante na regulação da motilidade e na capacitação dos espermatozoides. Estudos indicam que o NO é capaz de regular a concentração da AMP cíclico e, por conseguinte, através da atividade da adenil ciclase, estimular a capacitação espermática em várias espécies. O objetivo deste estudo foi avaliar a função do NO na capacitação de espermatozoides equinos criopreservados. Três ejaculados foram colhidos de três garanhões $(n=9)$. O sêmen foi diluído em meio Botu-Crio $^{\circledR}$ na concentração final de $200 \times 10^{6}$ células $/ \mathrm{mL}$, envasado em palhetas de 0,5 $\mathrm{mL}$ e criopreservado usando um sistema automatizado. Para cada análise, foram descongeladas quatro palhetas da mesma partida e do mesmo garanhão em banho-maria a $37^{\circ} \mathrm{C} / 30$ s. e em seguida, o sêmen foi submetido à centrifugação em meio FIV. Posteriormente, o sêmen foi incubado neste mesmo meio na presença de L-arginina, com ou sem inibidor da enzima óxido nítrico sintase o (L-NAME), e com ou sem o removedor de NO (azul de metileno) nos tratamentos: 1) $\mathrm{C}=(\mathrm{FIV}) ; 2) \mathrm{A}=\mathrm{L}$-arginina (10 mM); 3) L = L-NAME (1 mM); 4) M = azul de metileno (100 mM); 5) AL = Larginina $(10 \mathrm{mM})+\mathrm{L}-\mathrm{NAME}(1 \mathrm{mM}) ; 6) \mathrm{AM}=\mathrm{L}$-arginina $(10 \mathrm{mM})+$ azul de metileno $(100 \mathrm{mM})$. As amostras foram incubadas a $38^{\circ} \mathrm{C}$ e $5 \%$ de $\mathrm{CO}_{2}$. Após a incubação realizou-se a análise computadorizada da motilidade do espermatozoide e as análises por citometria de fluxo. Para a análise computadorizada da motilidade espermática foram avaliados os tempos de incubação de 0, 60, 120 e 300 min. e para as análises por citometria de fluxo os tempos de 60, 120 e 300 min. Para avaliar a integridade das membranas plasmática e acrossomal usou-se a associação FITC-PSA e IP. Para a detecção da fosforilação do aminoácido tirosina, usou-se o anticorpo antifosfotirosina conjugado a uma fluoresceína (DAF-2). A fim de dosar a quantidade de NO produzido 
pelo espermatozoide equino criopreservado foi utilizada a sonda DAF e para avaliar a peroxidação lipídica da membrana espermática utilizou a sonda C11-BODIPY. A sonda H33342 foi usada com a finalidade de evitar que partículas do mesmo tamanho e granulosidade da célula espermática fossem incluídas na contagem das análises por citometria de fluxo. Os dados foram analisados por meio da ANOVA e a comparação das médias, dentro de cada tempo, pelo teste de Tukey, com o nível de significância de $5 \%$, usando o software SAS. A remoção do NO do meio de cultura inibiu a motilidade das células espermáticas em todos os tempos de incubação. A motilidade total e motilidade progressiva foram reduzidas nos grupos M e AM. Os espermatozoides incubados com o removedor do NO apresentaram maior porcentagem de células com membrana plasmática e acrossomal íntegras nos 60 e 120 minutos de incubação $(\mathrm{p}<0,05)$. A reação acrossomal foi induzida nos tratamentos que receberam L-arginina (A; AL). Dentro de cada tratamento, a quantidade de NO produzido pelo espermatozoide, a fosforilação do aminoácido tirosina e a peroxidação lipídica não apresentaram diferenças entre os tempos $(p>0,05)$. Foi verificada uma redução destas variáveis nos grupos M e AM (p<0,05). Contudo, a dose de $1 \mathrm{mM}$ de L-NAME, não foi suficiente para inibir a NOS em espermatozoides criopreservados de equinos. A remoção do NO mantém a integridade das membranas plasmática e acrossomal, entretanto inibe totalmente a motilidade espermática, sugerindo um papel benéfico do NO endógeno na manutenção da motilidade dos espermatozoides equinos criopreservados.

Palavras chave: Espermatozoide. Capacitação. Óxido Nitrico. L-arginina. L-NAME. Azul de metileno. 


\begin{abstract}
FRANCO-SILVA, D. Evaluation of the role of nitric oxide in capacitation of cryopreserved equine spermatozoa [Avaliação da função do óxido nítrico na capacitação do espermatozoide equino criopreservado]. 2013. 116f. Dissertação (Mestrado em Ciências) - Faculdade de Medicina Veterinária e Zootecnia, Universidade de São Paulo, Pirassununga, 2013
\end{abstract}

Capacitation is an essential physiological prerequisite in order to sperm cell fertilize the oocyte. Nitric oxide (NO) is synthesized in vivo during the conversion of L-arginine in L-citruline by oxidative reactions catalyzed by nitric oxide synthase enzyme (NOS) and plays an important role in regulation of motility and in sperm capacitation. Studies indicated that NO is capable of regulating cAMP concentration and, therefore, by adenylyl cyclase, stimulate sperm capacitation in several species. The aim of this study was to evaluate the function of nitric oxide in cryopreserved equine sperm capacitation. Three ejaculates from three stallions were collected $(n=9)$. Semen samples were diluted with Botu-Crio® extender to a final concentration of $200 \times 10^{6}$ sperms $/ \mathrm{mL}$, and then packaged in $0.5 \mathrm{~mL}$ straws and cryopreserved using an automated freezing system. For each analysis, four straws from the same batch and the same stallion were thawed in a water bath at $37^{\circ} \mathrm{C} / 30$ s. washed by centrifugation in FIV medium. Thereafter, samples were incubated in FIV medium in the presence of L-arginine, with or without the inhibitor of nitric oxide sinthase (L-NAME), and with or without the scavenger of NO (Methylene blue) in the following treatments: 1) $\mathrm{C}=$ Control (FIV); 2) $\mathrm{A}=\mathrm{L}$-arginine $10 \mathrm{mM}$; 3) L = L-NAME 1mM; 4) $\mathrm{M}=$ Methylene blue $100 \mathrm{mM}$; 5) $\mathrm{AL}=\mathrm{L}$-arginine $(10 \mathrm{mM})+\operatorname{L-NAME}(1 \mathrm{mM}) ; 6) \mathrm{AM}=\operatorname{L-argine}(10 \mathrm{mM})+$ Methylene blue $(100 \mathrm{mM})$. The treatments were incubated at $38^{\circ} \mathrm{C}$ and $\mathrm{CO}_{2}$ at $5 \%$. After incubation, the computer-assisted sperm motility (CASA) and flow cytometry analyses were performed. For CASA analysis, the incubation times of 0, 60, 120 e 300 min. were evaluated and for flow cytometry analyses times 60, 120 e 300 min. were evaluated. Plasma and acrosomal membranes integrity were evaluated by FITC-PSA and PI association. In order to detect amino acid tyrosine phosphorylation, we used the anti-phosphotyrosine antibody conjugated to a fluorescein (DAF-2). In order to quantify the amount of nitric oxide produced by cryopreserved equine sperm, the fluorescent probe DAF was used, and to evaluate the lipid peroxidation of sperm membrane we 
used the probe BODIPY-C11. The probe $\mathrm{H} 33342$ was used in order to prevent that particles of the same size and granularity of sperm cell were included in the counting of flow cytometry analyses. Data were analyzed by ANOVA and comparison of means within each time by the Tukey test, at a significance level of 5\%, using SAS software. Removing NO from the culture medium inhibited the motility of sperm cells at all incubation times. Total and progressive motilities were reduced in both groups, $\mathrm{M}$ and AM. Sperms incubated with the scavenger of NO had the highest percentage of cells with intact plasma and acrosomal membranes at 60 and 120 minutes of incubation (p $<0.05)$. Acrosomal reaction was induced in treatments with L-arginine (A, AL). Within each treatment, the amount of NO produced by sperms, the level of amino acid tyrosine phosphorylation and lipid peroxidation had no differences between the times used ( $\mathrm{p}$ $0.05)$. A reduction of these variables in groups $M$ and AM ( $\mathrm{p}<0.05)$ was observed. However, a dose of $1 \mathrm{mM}$ L-NAME was not sufficient to inhibit NOS in cryopreserved equine sperm. Removal of NO maintains plasma and acrosomal membranes integrity, however completely inhibits sperm motility, suggesting a beneficial role of endogenous NO in the maintenance of motility of cryopreserved equine spermatozoa.

Keywords: Sperm. Capacitation. Nitric Oxide. L-arginine. L-NAME. Methylene blue. 


\section{LISTA DE ILUSTRAÇÕES}

Figura 1 - $\quad$ Modelo hipotético gráfico 53

Figura 2 - Esquema simplificado do delineamento experimental 56

Figura 3 - $\quad$ Médias \pm desvios padrão da motilidade total (MT, \%) em função dos 65 tempos de incubação $(0,60,120$ e 300 min) e dos tratamentos $(C, L$, M, A, AL e AM) - Pirassununga - 2013

Figura 4 - Médias \pm desvios padrão da motilidade progressiva (MP, \%) em função dos tempos de incubação $(0,60,120$ e 300 min) e dos tratamentos (C, L, M, A, AL e AM) - Pirassununga - 2013

Figura 5 - Médias \pm desvios padrão da velocidade de trajeto (VAP, $\mu \mathrm{m} / \mathrm{s}$ ) em função dos tempos de incubação $(0,60,120$ e $300 \mathrm{~min})$ e dos tratamentos (C, L, M, A, AL e AM) - Pirassununga - 2013

Figura 6 - Médias \pm desvios padrão do efeito dos tratamentos $(C, L, M, A, A L$ e AM) na velocidade de trajeto (VAP, $\mu \mathrm{m} / \mathrm{s}$ ) - Pirassununga - 2013

Figura 7 - Médias \pm desvios padrão da velocidade progressiva (VSL, $\mu \mathrm{m} / \mathrm{s}$ ) em função dos tempos de incubação $(0,60,120$ e $300 \mathrm{~min})$ e dos tratamentos (C, L, M, A, AL e AM) - Pirassununga - 2013

Figura 8 - Médias \pm desvios padrão da velocidade curvilinear (VCL, $\mu \mathrm{m} / \mathrm{s}$ ) em função dos tempos de incubação $(0,60,120$ e $300 \mathrm{~min})$ e dos tratamentos (C, L, M, A, AL e AM) - Pirassununga - 2013

Figura 9 - Médias \pm desvios padrão do efeito dos tratamentos $(\mathrm{C}, \mathrm{L}, \mathrm{M}, \mathrm{A}, \mathrm{AL}$ e AM) na velocidade curvilinear (VCL, $\mu \mathrm{m} / \mathrm{s}$ ) - Pirassununga 2013

Figura 10 - Médias \pm desvios padrão da amplitude do deslocamento lateral da cabeça (ALH) em função dos tempos de incubação $(0,60,120$ e 300 min) e dos tratamentos (C, L, M, A, AL e AM) - Pirassununga $-2013$

Figura 11 - Médias \pm desvios padrão do efeito dos tratamentos $(C, L, M, A, A L$ e AM) na amplitude do deslocamento lateral da cabeça (ALH, $\mu \mathrm{m})$ - Pirassununga - 2013

Figura 12 - Médias \pm desvios padrão da frequência de batimentos (BCF, Hz) em função dos tempos de incubação $(0,60,120$ e $300 \mathrm{~min})$ e dos tratamentos (C, L, M, A, AL e AM) - Pirassununga - 2013

Figura 13 - Médias \pm desvios padrão da retilinearidade (STR, \%) em função dos tempos de incubação $(0,60,120$ e $300 \mathrm{~min})$ e dos tratamentos $(\mathrm{C}, \mathrm{L}$, M, A, AL e AM) - Pirassununga - 2013

Figura 14 - Médias \pm desvios padrão do efeito dos tratamentos $(\mathrm{C}, \mathrm{L}, \mathrm{M}, \mathrm{A}, \mathrm{AL}$ e AM) na retilinearidade (STR, \%) - Pirassununga - 2013

Figura 15 - Médias \pm desvios padrão da linearidade (LIN, \%) em função dos tempos de incubação $(0,60,120$ e $300 \mathrm{~min})$ e dos tratamentos $(\mathrm{C}, \mathrm{L}$, M, A, AL e AM) - Pirassununga - 2013

Figura 16 - Médias \pm desvios padrão da porcentagem de células rápidas (RAP) em função dos tempos de incubação $(0,60,120$ e $300 \mathrm{~min})$ e dos tratamentos (C, L, M, A, AL e AM) - Pirassununga - 2013

Figura 17 - Médias \pm desvios padrão da porcentagem de células hiperativadas (\%) em função dos tempos de incubação $(0,60,120$ e $300 \mathrm{~min})$ e dos tratamentos (C, L, M, A, AL e AM) - Pirassununga - 2013 
Figura 18 - Médias \pm desvios padrão do efeito dos tratamentos $(\mathrm{C}, \mathrm{L}, \mathrm{M}, \mathrm{A}, \mathrm{AL}$ e AM) na porcentagem de células hiperativadas (\%) - Pirassununga $-2013$

Figura 19 - Médias \pm desvios padrão da porcentagem de células com membrana plasmática e acrossomal íntegras (IAIM, \%) em função dos tempos de incubação (60, 120 e 300 min) e dos tratamentos (C, L, M, A, AL e AM) - Pirassununga - 2013

Figura 20 - Médias \pm desvios padrão da porcentagem de espermatozoides íntegros apresentando reação acrossômica (RAIM, \%) em função dos tempos de incubação $(60,120$ e $300 \mathrm{~min})$ e dos tratamentos $(\mathrm{C}$, L, M, A, AL e AM) - Pirassununga - 2013

Figura 21 - Médias \pm desvios padrão do efeito dos tratamentos $(C, L, M, A, A L$ e AM) na reação acrossômica (RAIM, \%) - Pirassununga - 2013

Figura 22 - Médias \pm desvios padrão da produção de óxido nítrico pelos espermatozoides íntegros (NO+, a.u.) em função dos tempos de incubação (60, 120 e $300 \mathrm{~min})$ e dos tratamentos (C, L, M, A, AL e AM) - Pirassununga - 2013

Figura 23 - Médias \pm desvios padrão do efeito dos tratamentos $(\mathrm{C}, \mathrm{L}, \mathrm{M}, \mathrm{A}, \mathrm{AL}$ e AM) na produção de óxido nítrico pelos espermatozoides íntegros (NO+, a.u.) - Pirassununga - 2013

Figura 24 - Médias \pm desvios padrão da fosforilação do aminoácido tirosina presente na superfície dos espermatozoides íntegros (ANT+, a.u.) em função dos tempos de incubação $(60,120$ e 300 min) e dos tratamentos (C, L, M, A, AL e AM) - Pirassununga - 2013

Figura 25 - Médias \pm desvios padrão do efeito dos tratamentos $(C, L, M, A, A L$ e AM) na fosforilação do aminoácido tirosina presente na superfície dos espermatozoides íntegros (ANT+, a.u.) - Pirassununga - 2013

Figura 26 - Médias \pm desvios padrão da peroxidação lipídica das membranas espermáticas íntegras (BODI+, a.u.) em função dos tempos de incubação $(60,120$ e 300 min) e dos tratamentos (C, L, M, A, AL e AM) - Pirassununga - 2013

Figura 27 - Médias \pm desvios padrão do efeito dos tratamentos $(C, L, M, A, A L$ e AM) na peroxidação lipídica das membranas espermáticas íntegras (BODI+, a.u.) - Pirassununga - 2013 


\section{LISTA DE QUADROS}

Anexo A Preparo do meio FIV (estoque)

Quadro 1 -

Anexo A Meio FIV trabalho

Quadro 2 -

Anexo A Solução antibiótico

Quadro 3 -

Anexo A Penicilamina

Quadro 4 -

Anexo A Hipotaurina

Quadro 5

Anexo A Solução I

Quadro 6-

Anexo A Solução II

Quadro 7 -

Anexo B Ajuste do IVOS 12.3 para análise de sêmen equino Quadro 8 - 


\section{LISTA DE GRÁFICOS}

Gráfico 1 - Gráficos de pontos e histogramas gerados pela análise de 10.000 células por citometria de fluxo. Amostra corada com a associação H33342, Iodeto de Propídio, FITC-PSA permitindo a classificação dos espermatozoides equinos em quatro categorias - Pirassununga - 2013

Gráfico 2 - Gráficos de pontos gerados pela análise por citometria de fluxo em amostra corada com a associação de H33342, com anticorpo antifosfotirosina conjugado ao FITC e a sonda fluorescente Iodeto de Propídio - Pirassununga 2013

Gráfico 3 - Gráfico de pontos gerados pela análise por citometria de fluxo em amostra corada com a associação de H33342, mais 4,5-diaminofluorescein-2/diacetate e Iodeto de Propídio - Pirassununga - 2013

Gráfico 4 - Gráfico de pontos gerados pela análise por citometria de fluxo em amostra corada com a associação de H33342, $\mathrm{C}_{11}$ BODIPY e a sonda fluorescente Iodeto de Propídio Pirassununga - 2013 


\section{LISTA DE ABREVIATURAS E SIGLAS}

\begin{tabular}{|c|c|}
\hline$\mu_{14}$ & Micrometros \\
\hline A & carbono 14 \\
\hline & L-arginina \\
\hline $\mathrm{AC}$ & adenil ciclase \\
\hline ADMA & Dimetilarginina \\
\hline AIMI & $\begin{array}{l}\text { membrana plasmática íntegra e membrana acrossomal } \\
\text { íntegra }\end{array}$ \\
\hline ALH & amplitude do deslocamento lateral da cabeça \\
\hline $\mathrm{AM}$ & L-arginina + azul de metileno \\
\hline AMPc & adenosina-monofosfato cíclica \\
\hline $\mathrm{BCF}$ & frequência de batimento flagelar \\
\hline BSA & albumina sérica bovina \\
\hline $\mathrm{C}$ & Controle \\
\hline C11BODIPY 581/591 & $\begin{array}{l}\text { 4,4-difluoro-5-(4-phenyl-1,3-butadienyl)-4-bora- } 3^{\mathrm{a}}, 4^{\mathrm{a}} \text { - } \\
\text { diaza-sindacene-3-undecanoic acid }\end{array}$ \\
\hline $\mathrm{Ca}$ & Cálcio \\
\hline $\mathrm{Ca}^{2+}$ & íon cálcio \\
\hline $\mathrm{CaCl}_{2} \cdot 2 \mathrm{H}_{2} \mathrm{O}$ & cloreto de cálcio bihidratado \\
\hline CAPSper & canais de cálcio espermatozoide -específicos \\
\hline CASA & $\begin{array}{l}\text { Computer assisted semen analisys (análise } \\
\text { computadorizada do sêmen) }\end{array}$ \\
\hline cGMP & monofosfato cíclico de guanosina \\
\hline CLONE PY-20 & Anticorpo antifosfotirosina conjugado a uma fluoresceína \\
\hline cNOS & óxido nítrico sintase constitutiva \\
\hline CTC & Clortetraciclina \\
\hline DAF & 4,5-diacetato diaminofluorescein-2/diacetato (daf) \\
\hline DAG & Diacilglicerol \\
\hline dbcAMP & dibutiril AMP cíclico \\
\hline DNA & ácido desoxirribonucléico \\
\hline EDRF & fator de relaxamento do endotélio vascular \\
\hline EGb 761 & ginkgo biloba \\
\hline eNOS & óxido nítrico sintase endotelial \\
\hline EROs & espécies reativas de oxigênio \\
\hline FIV & meio de fertilização in vitro \\
\hline g & Grama \\
\hline GC & Guanilato ciclase \\
\hline GMP & Monofosfato 3',5'- cíclico da guanosina \\
\hline GTP & Guanosina 5'-trifosfato \\
\hline $\mathrm{H}_{2} \mathrm{O}_{2}$ & peróxido de hidrogênio \\
\hline H33342 & Hoeschst 33342 \\
\hline $\mathrm{HCO}_{3}^{-}$ & íon bicarbonato \\
\hline HDL & Lipoproteína de alta densidade \\
\hline $\mathrm{HFF}$ & fluido folicular \\
\hline HNF & 4 - hidroxinonenal \\
\hline HOONO & Radical hidroxila \\
\hline $\mathrm{Hr}$ & Horas \\
\hline
\end{tabular}




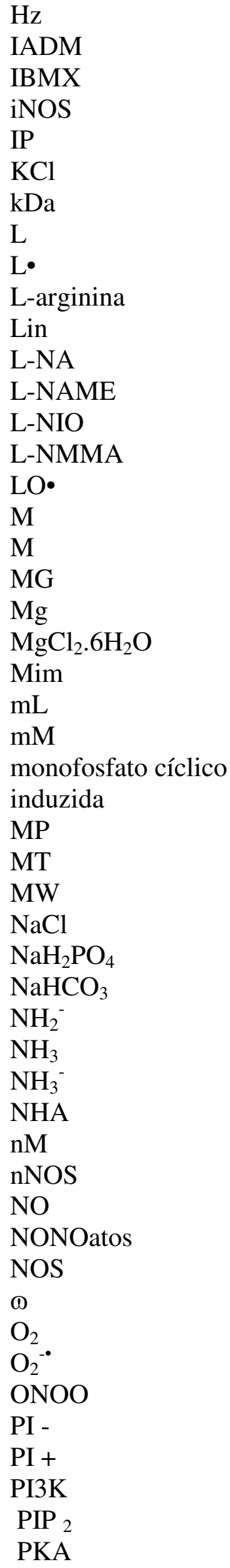

Hertz

membrana plasmática

3-isobutil-metilxantina

óxido nítrico sintase induzível

iodeto de propídio

cloreto de potássio

Quilodalton

L-name

radical alquila

$\mathrm{N}^{\mathrm{G}}$-nitro-1-arginina

Linearidade

$\mathrm{N}^{\mathrm{G}}$-nitro-l-arginina

$\mathrm{N}^{\mathrm{G}}$-nitro-l-arginina metil éster

$\mathrm{N}$-iminoetil-l-ortinina

$\mathrm{N}^{\mathrm{G}}$-monometil-1-arginina

radical alcoxila

azul de metileno

Molaridade

Miligrama

Magnésio

cloreto de magnésio hexahidratado

Minuto

Mililitro

Milimolar

cGMP-induzida

motilidade progressiva

motilidade total

meio Whitten modificado

cloreto de sódio

bifosfato de sódio

bicarbonato de sódio

Nitrato

Amônia

Nitrito

$\mathrm{N}$ w-hidroxy-arginina

Nanomolar

óxido nítrico sintase neuronal

óxido nítrico

compostos que liberam o no no meio de incubação

óxido nítrico sintase

Omega

Oxigênio

ânion superóxido

Peroxinitrito

Células viáveis (íntegras)

Células não viáveis (não íntegras)

fosfatidil-inositol-3-quinase

fosfatidil-inositol bisfosfato

proteína kinase $\mathrm{A}$ 


$\begin{array}{ll}\text { PKC } \alpha & \text { proteína quinase C } \alpha \\ \text { PLD } & \text { fosfolipase D } \\ \text { PNA } & \text { aglutinina de amendoin } \\ \text { PP1 } \gamma_{2} & \text { fosfatidil-inositol-fosfato } \\ \text { PSA } & \text { aglutinina de Pisum sativum } \\ \text { PTIO } & 2 \text {-fenil-4,4,5,5-tetrametilimidazoline } \\ \text { radical peroxila } & \text { LOO } \\ \text { RADM } & \text { membrana plasmática lesada e membrana acrossomal } \\ & \text { reagida } \\ \text { RAIM } & \text { membrana plasmática íntegra e membrana acrossomal } \\ & \text { reagida } \\ \text { RAP } & \text { porcentagem de células rápidas } \\ \text { S } & \text { Segundos } \\ \text { SAC } & \text { isoforma da adenilil ciclase } \\ \text { SAS } & \text { Statistical analysis system (sistema de análise estatística) } \\ \text { SMTC } & \text { S-metil-L-tiocitrulina } \\ \text { SOD } & \text { superóxido desmutase } \\ \text { STR } & \text { retilinearidade } \\ \text { ua } & \text { unidades arbitrárias } \\ \text { VAP } & \text { velocidade de trajeto } \\ \text { VCL } & \text { velocidade curvilinear } \\ \text { VSL } & \text { velocidade progressiva } \\ \text { ZP } & \text { zona pelúcida } \\ \text { ZP3 } & \text { zona pelúcida glicoproteína 3 } \\ \text { B } & \text { Beta } \\ \mu L & \text { Microlitro } \\ \text { Mm } & \text { Micromolar } \\ & \end{array}$




\section{LISTA DE SÍMBOLOS}

\begin{tabular}{ll}
${ }^{\circ} \mathrm{C}$ & graus Celsius \\
$\%$ & Porcentagem \\
$\times$ & Vezes \\
$10^{6}$ & Milhões \\
$:$ para & $(1: 1)$ \\
$\circledR$ & marca registrada \\
$<$ & menor que \\
$>$ & maior que \\
\pm & mais ou menos \\
- & menos / negativo \\
+ & mais/positivo \\
$=$ & Igual \\
\hline & Grau
\end{tabular}




\section{SUMÁRIO}

\begin{tabular}{|c|c|c|}
\hline 1 & 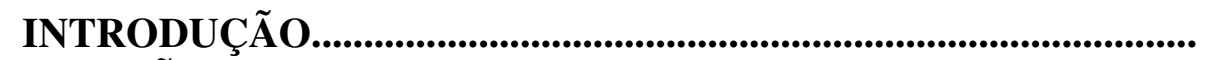 & \\
\hline 2 & 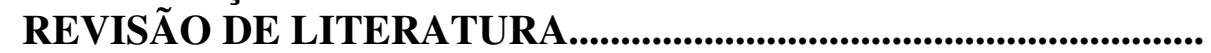 & \\
\hline 2.1 & CAPACITAÇÃO, REAÇÃO ACROSSÔMICA E HIPERATIVAÇÃO & \\
\hline \multirow[t]{2}{*}{2.2} & CAPACITAÇÃO, REAÇÃO ACROSSÔMICA E HIPERATIVAÇÃO & \\
\hline & EM ESPERMATOZOIDES DE EQUINOS & \\
\hline 2.3 & ÓXIDO NÍTRICO.. & \\
\hline 2.4 & ÓXIDO NÍTRICO E O ESPERMATOZOIDES. & \\
\hline 2.5 & L-ARGININA: PRECURSORA DO ÓXIDO NÍTRICO.. & \\
\hline 2.6 & INIBIDORES DO ÓXIDO NÍTRICO... & \\
\hline 2.7 & REMOVEDORES (SCAVENGERS) DO ÓXIDO NÍTRICO... & \\
\hline 3 & OBJETIVOS & \\
\hline 3.1 & OBJETIVO GERAL........... & \\
\hline 3.2 & OBJETIVOS ESPECÍFICOS...... & \\
\hline 4 & 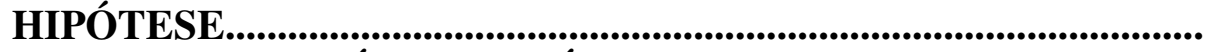 & \\
\hline 5 & 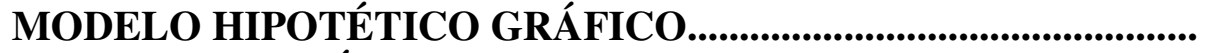 & \\
\hline 6 & MATERIAL E MÉTODOS & \\
\hline 6.1 & LOCAL. & \\
\hline 6.2 & ......................... & \\
\hline 6.3 & COLHEITA DE SÊMEN E AVALIAÇÃO ESPERMÁTICA................. & \\
\hline 6.4 & CONGELAÇÃO.... & \\
\hline 6.5 & MEIO DE INCUBAÇÃO ESPERMÁTICA.. & \\
\hline 6.6 & DESCONGELAÇÃO DO SÊMEN, CENTRIFUGAÇÃO $\quad$ E & \\
\hline 6.7 & DELINEAMENTO EXPERIMENTAL. & \\
\hline 6.7.1 & 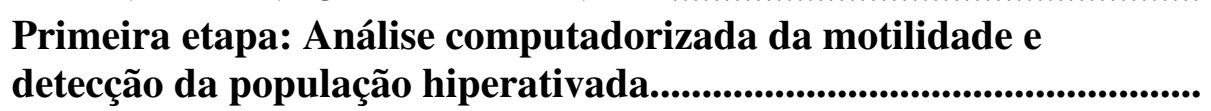 & \\
\hline 6.7.2 & Segunda etapa: Análise por citometria de fluxo................................... & \\
\hline 6.7.2.1 & $\begin{array}{l}\text { Detecção da fosforilação do aminoácido tirosina presente na superfície } \\
\text { da membrana plasmática }\end{array}$ & \\
\hline 6.7.2.2 & $\begin{array}{l}\text { Dosagem por citometria de fluxo da quantidade de óxido nítrico } \\
\text { produzido pelo espermatozoide }\end{array}$ & \\
\hline 6.7.2.3 & Avaliação da peroxidação espermática por citometria de fluxo............... & \\
\hline 6.8 & 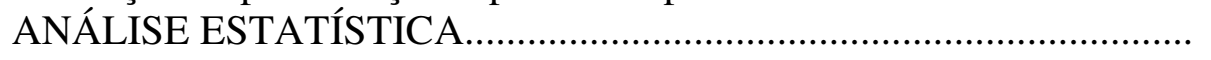 & \\
\hline 7 & RESULTADOS........... & \\
\hline \multirow[t]{2}{*}{7.1} & PARTE 1: AVALIAÇÃO DAS CARACTERÍSTICAS DA & \\
\hline & MOTILIDADE E DETECÇÃO DA POPULAÇÃO HIPERATIVADA & \\
\hline 7.2 & PARTE 2: AVALIAÇÃO POR CITOMETRIA DE FLUXO................. & \\
\hline 8 & DISCUSSÃO.. & \\
\hline \multirow[t]{3}{*}{9} & 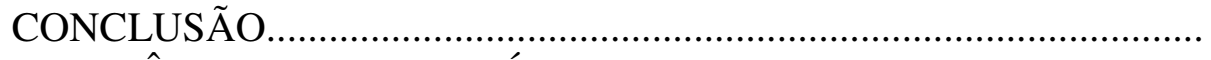 & \\
\hline & REFERÊNCIAS BIBLIOGRÁFICAS & \\
\hline & ANEXO & \\
\hline
\end{tabular}




\section{INTRODUÇÃO}

A criopreservação é uma biotécnica que causa danos aos espermatozoides (WATSON, 2000). A congelação e a descongelação são passos importantes na criopreservação espermática, uma vez que provoca efeitos sobre a estrutura e função celular (HAMMERSTEDT; GRAHAM; NOLAN, 1990), reduz a motilidade e capacidade fertilizante (HAMMERSTEDT, 1993), induz a capacitação prematura e a descondensação nuclear (CORMIER; SIRARD; BEILEY, 1997). Portanto, mesmo levando em consideração o uso de crioprotetores como o glicerol, a gema de ovo e o leite, alterações significativas são evidenciadas no acrossoma (WATSON, 1995), nas mitocôndrias e na membrana plasmática (FORERO-GONZALEZ et al., 2012). Por este motivo, é importante enfatizar que, a maior parte da população de células espermáticas sobreviventes exibe algum grau de danos subletais, tais como a peroxidação lipídica, o envelhecimento precoce das células (ação das espécies reativas de oxigênio (EROS) e a criocapacitação) e as transições de fase de membrana (WATSON, 2000), que diminuem seu tempo de vida dentro do trato reprodutor da fêmea, sugerindo uma situação problemática, principalmente para as espécies que apresentam longos períodos de estro, onde exames frequentes são necessários para executar inseminações artificiais próximas o suficiente da ovulação (FERRUSOLA et al., 2009a).

Um dos grandes problemas da técnica de criopreservação espermática na espécie equina, está relacionada a grande variabilidade inter-individual na sobrevivência de espermatozóides durante os procedimentos de congelação e descongelação. Tal variabilidade é muitas vezes atribuída ao fato de que a maioria dos garanhões foram selecionados pelo seu desempenho e fenótipo, e não pela qualidade espermática. No entanto, as razões fisiológicas e bioquímicas por trás dessa variabilidade permanecem sem explicação (FERRUSOLA et al., 2009b)

Watson, (2000) descreveu que a criopreservação induz a formação de um excesso de espécies reativas de oxigênio (EROS) tais como, o peróxido de hidrogênio, o anion superóxido e os radicais hidroxila, (BAUMBER et al., 2000; AGARWALL; SAID, 2005) reduzindo a qualidade espermática em várias espécies. Os espermatozoides de equinos são capazes de gerar (EROS) (BAUMBER et al., 2000) por um mecanismo que se acredita envolver uma oxidase nicotinamida adenina dinucleótido 
fosfato (NADPH) semelhante ao relatado em espermatozoides de humanos (AITKEN; BUCKINGHAM; WEST, 1992). A criopreservação nas células espermáticas de equinos pode induzir a produção de óxido nítrico (NO) mesmo em espermatozoides de garanhão com boa qualidade pós-descongelação (FERRUSOLA et al., 2009a).

A capacitação é um termo descrito como uma série de eventos que ocorrem no espermatozoide para que ele fertilize o oócito. Embora a capacitação seja conseguida de forma sinérgica e eficientemente no trato reprodutivo da fêmea, ela também pode ser realizada in vitro em meios bem definidos em várias espécies de mamíferos (O'FLAHERTY; RODRIGUEZ; SRIVASTAVA, 2004). Os eventos da capacitação não são bem caracterizados e o seu impacto sobre a fertilidade do garanhão ainda é pouco conhecida.

A capacitação pode ser conseguida in vitro em solução salina equilibrada contendo concentrações apropriadas de eletrólitos, fontes de energia metabólica, e albumina sérica bovina (BSA). Em humanos, um método para medir a capacitação é através da eficiência dos espermatozoides em apresentarar reação acrossômica (ICKOWICZ; FINKELSTEIN; BREITBART, 2012). Salienta-se que nos espermatozoides de equinos uns dos eventos mais importantes para determinar a capacitação espermática é a presença da fosforilação dos resíduos do aminoácido tirosina (MCPARTLIN et al., 2008). Diferentes estímulos, como a progesterona, o fluido folicular, zona pelúcida, e o cálcio $\left(\mathrm{Ca}^{2+}\right)$ podem desencadear a reação acrossômica. Durante a capacitação, as mudanças no espermatozoide como alteração das concentrações de íons intracelulares, a fluidez da membrana plasmática e motilidade são eventos fundamentais para este processo (YANAGIMACHI, 1994). Além disso, o aumento da concentração da adenosina monofosfato cíclica (AMP cíclico) (KOPF; VISCONTI; GALANTINO-HOMER, 1999) e a fosforilação dos resíduos do aminoácido tirosina também estão envolvidos (VISCONTI et al., 1995). Estudos recentes indicam que o anion superóxido $\left(\mathrm{O}_{2}{ }^{-}\right)$(de LAMIRANDE, GAGNON, 1992; GRIVEAU; RENARD; LE LANNOU, 1995) o peróxido de hidrogênio, $\left(\mathrm{H}_{2} \mathrm{O}_{2}\right)$ (GRIVEAU; RENARD; LE LANNOU, 1994) e óxido nítrico (NO) (VEDANTAM; ATREJA; GARG, 2012) participam da capacitação espermática. No entanto, embora o número de estudos sobre esses eventos estejam crescendo, as interações entre as diferentes vias de sinalização envolvidas na capacitação espermática ainda permanecem pouco elucidadas. 
O NO é um radical livre produzindo a partir de uma série de reações moduladas pela enzima oxido nítrico sintase (NOS) (MONCADA; PALMER; HIGGS, 1991). Até o momento, três isoformas de NOS foram purificadas, sequenciadas e caracterizadas: duas delas são NOS neuronal (nNOS) e NOS endotelial (eNOS) que têm sido referidas como constitutivas (cNOS), ativadas por cálcio e calmodulina, e são seletivamente inibidas pela $\mathrm{N}^{\mathrm{G}}$-nitro-L-arginina metil éster (L-NAME) e $\mathrm{N}^{\mathrm{G}}$-nitro-L-arginina (L-NA). Existe também uma terceira forma induzível (iNOS), que é cálcio independente (MONCADA; PALMER; HIGGS, 1991). O NO é um importante modulador das funções celulares. É um vasodilatador potente que tem sido identificado em numerosos processos fisiológicos, farmacológicos e patológicos (MONCADA; PALMER; HIGGS, 1991). Também é uma molécula mensageira muito importante, envolvida em vários aspectos da reprodução, tais como, o desenvolvimento folicular (JABLONKASHARIFF; OLSON, 2000) a ovulação, (OLSON et al., 1999) a esteroidogenese (JABLONKA-SHARIFF; OLSON, 1998) e a maturação de oócitos (SCHWARZ et al., 2008). Em espermatozoides, o NO parece desempenhar um papel importante na regulação da motilidade e na capacitação (HELLSTROM et al., 1994; LEWIS et al., 1996). Herrero et al. (2000) relataram que o NO é capaz de regular a concentração de AMP cíclico e, por conseguinte, através da atividade da adenil ciclase (AC) estimular a capacitação espermática em várias espécies (MURAD, 1994; HELLSTROM et al., 1994; LEWIS et al., 1996). Estudos indicam que baixas concentrações de NO melhoram a motilidade e promovem um aumento significativo da capacitação espermática e reação acrossômica em humanos e ratos (ZINI; de LAMIRANDE; GAGNON, 1995; HERRERO; de LAMIRANDE; GAGNON, 1999; REVELLI et al., 2001 ). No entanto, pouco se sabe sobre o efeito do NO na capacitação de espermatozoides de equinos.

O NO está presente nos espermatozoides equinos (FERRUSOLA et al., 2009a). No entanto, são escassos na literatura científica, trabalhos que elucidem a importância deste radical livre na motilidade e na capacitação do espermatozoide equino criopreservado. $\mathrm{O}$ presente experimento foi realizado com o objetivo de verificar o efeito da inibição, da indução e da remoção do NO, no meio de capacitação, sobre os padrões de motilidade, hiperativação, integridade de membrana plasmática e acrossomal, fosforilação do aminoácido tirosina, quantidade de NO produzido e peroxidação lipídica de espermatozoides equinos criopreservados. 


\section{REVISÃO DE LITERATURA}

\subsection{CAPACITAÇÃO, REAÇÃO ACROSSÔMICA E HIPERATIVAÇÃO}

A sequência de eventos moleculares e fisiológicos que envolvem as mudanças na fluidez da membrana, na concentração iônica intracelular, no metabolismo energético e nos padrões de motilidade que conferem ao espermatozoide a habilidade de fertilizar o oócito durante o período de permanência no trato reprodutor da fêmea é chamado de capacitação (SUAREZ, 1996; VISCONTI et al., 1998). Assim, o espermatozoide é preparado para a fecundação, mais especificamente, para ser submetido à reação acrossômica (SUAREZ, 1996), considerada a etapa final da capacitação (VISCONTI et al., 1998). Outros autores consideram a capacitação como a aquisição da habilidade do espermatozoide com acrossoma intacto sofrer reação acrossômica, em resposta à sua interação com a zona pelúcida (ZP), a matriz extracelular do oócito (VISCONTI et al., 1995).

A capacitação foi identificada pela primeira vez por Austin (1951; 1952), descrevendo suas observações com relação à penetração de espermatozoides no oócito de ratas e de coelhas, sendo dirigida atenção particular para a passagem dos espermatozoides através da zona pelúcida e da superfície do vitelo; e por Chang (1951), em suas pesquisas com coelhas, relatando as possíveis mudanças fisiológicas do espermatozoide dentro do trato reprodutor da fêmea.

Considerando a complexidade no ambiente do aparelho reprodutor da fêmea, da posição anatômica do oócito e o local de deposição do espermatozoide, é pertinente supor que, o processo de capacitação e reação acrossômica deve ser espacialmente e temporalmente controlados para evitar a indução prematura da hiperativação e da reação acrossômica (SAGARE-PATIL et al., 2012). Desta forma, o local fisiológico da capacitação in vivo, dependendo da espécie, é o oviduto ou o útero (VISCONTI; KOPF, 1998) podendo estes ambientes ser mimetizados in vitro em meios definidos (SIGNORELLI; DIAZ; MORALES, 2012). Embora em mamíferos sejam depositados milhões de espermatozoides no aparelho reprodutor da fêmea, este grande número por si 
só não garante a fecundação do oócito (CHANG; SUAREZ, 2010). Yanagimachi; Yanagimachi; Rogers (1976), verificando as interações de oócitos-espermatozoides entre vários animais, descobriram que os espermatozoides de humanos, que inicialmente eram incapazes de penetrar livremente a zona pelúcida de hamsters (Mesocricetus auratus), tornaram-se competentes de fazê-lo quando incubadas in vitro por quatro horas ou mais em meio definido, possibilitando, desta forma, a análise da capacidade de fertilização do espermatozoide humano in vitro.

Durante o processo de capacitação, a fosfatidil-inositol-3-quinase (PI3K) é fosforilada / ativada via uma cascata dependente de proteína kinase A (PKA) e de uma regulação negativa da proteína quinase $\mathrm{C} \alpha(\mathrm{PKC} \alpha)$. A PKC $\alpha$ é ativada no início de capacitação resultando na inativação da inositol trifosfato (PI3K). Durante a capacitação, PKC $\alpha$ bem como fosfatidil-inositol-fosfato (PP1 $\left.\gamma_{2}\right)$ é degradada por um mecanismo dependente de PKA, permitindo a ativação da PI3K. A ativação da PKA durante a capacitação depende principalmente de monofosfato ciclíco de adenosina (AMP ciclico) produzido pela adenil ciclase (AC) que é dependente de bicarbonato solúvel. Esta ativação da PKA conduz a um aumento da polimerização da actina, um processo essencial para alterações no padrão da motilidade (hiperativação), fator necessário para a uma fertilização bem sucedida. A polimerização da actina é mediada pelo fosfatidil-inositol bisfosfato $\left(\mathrm{PIP}_{2}\right)$ de duas maneiras: em primeiro lugar, $\mathrm{PIP}_{2}$ atua como um co-fator para a ativação da fosfolipase D (PLD), e em segundo lugar, como uma molécula que se liga e inibe a actina cortando proteínas, tais como a gelsolina. A fosforilação do aminoácido tirosina é importante durante a capacitação. Antes da reação acrossômica, a gelsolina é libertada da $\mathrm{PIP}_{2}$ e sofre desfosforilação resultando em despolimerização da F- actina levando por fim, à reação acrossômica (ICKOWICZ; FINKELSTEIN; BREITBART, 2012).

É possível que o $\mathrm{Ca}^{2+}$ esteja envolvido em iniciar ou regular a capacitação, no entanto essa afirmação é um tanto controversa (VISCONTI et al., 1995). Trabalhos demonstram que a despolarização da membrana pode abrir alguns canais de $\mathrm{Ca}^{2+}$ permitindo sua entrada. Assim, a atividade parece ser aumentada após os espermatozoides serem condicionados pelo bicarbonato $\left(\mathrm{HCO}_{3}{ }^{-}\right)(\mathrm{WENNEMUTH}$ et al., 2000). Em espermatozoides de ratos, existe a evidência de que o $\mathrm{Ca}^{2+}$ extracelular é necessário para capacitação (VISCONTI et al., 1995). Um aumento do $\mathrm{Ca}^{2+}$ intracelular durante a capacitação foi descrito por alguns pesquisadores, ao passo que, outros não 
demonstram nenhuma alteração durante este evento (YANAGIMACHI, 1994). Esta ambiguidade pode estar relacionada, em parte, à ação do $\mathrm{Ca}^{2+}$ sobre a reação acrossômica e às dificuldades inerentes na diferenciação destes eventos (VISCONTI et al., 1998). O provável mecanismo de ação do $\mathrm{Ca}^{2+}$ citoplasmático é ativar a adenil ciclase (AC) dependente de $\mathrm{Ca}^{2+}$, resultando em um aumento do AMP cíclico, que é responsável pelo batimento flagelar acelerado observado durante a hiperativação (FENG et al., 1988)

$\mathrm{O}$ ânion bicarbonato $\left(\mathrm{HCO}_{3}^{-}\right)$é a chave para a ativação dos espermatozoides, quando eles saem do epidídimo dos testículos de mamíferos. Os primeiros estudos (HAMNER; WILLIAMS, 1964) observaram que o ânion bicarbonato estimula a atividade respiratória de espermatozoides. Outros trabalhos indicam que este ânion é responsável pela alteração na arquitetura da membrana plasmática (HARRISON; ASHWORTH; MILLER, 1996), pelo aumento da motilidade progressiva (HOLT; HARRISON, 2002), além de aumentar a produção de AMP cíclico (BOATMAN; ROBBINS, 1991). Sabe-se também que o movimento transmembranar do $\mathrm{HCO}_{3}{ }^{-}$está associado ao aumento do $\mathrm{pH}$ intracelular observado durante a capacitação (VISCONTI, 2009). Estes efeitos são mediados pelo próprio $\mathrm{HCO}_{3}{ }^{-}$através da estimulação da atividade de uma isoforma da adenil ciclase (SAC) nos espermatozoides (LITVIN et al., 2003) onde, em seguida, o aumento dos níveis de AMP cíclico na célula (HARRISON; MILLER, 2000) ativam uma PKA (fosfoquinase A) dependente de AMP ciclíco que irá fosforilar diferentes proteínas alvo (HARRISON; GADELLA, 2005).

A albumina sérica bovina (BSA), um componente essencial do meio de capacitação in vitro, funciona como um carreador do colesterol, se ligando a este e removendo-o da membrana plasmática. Sabe-se que a capacitação pode ser inibida pela adição de colesterol e/ou análogos de colesterol ao meio de capacitação (CROSS, 1998). A albumina sérica bovina (BSA) pode ser substituída in vitro pela lipoproteína de alta densidade (HDL) e, demonstrou-se in vitro, que as BSPs (bovine seminal plasma proteins) estão envolvidas no efluxo de colesterol mediado pela HDL no espermatozoide bovino (THÈERIEN; SOUBEYRAND; MANJUNATH, 1997). A retirada do colesterol da membrana plasmática é um processo que antecede múltiplos sinais intrínsecos ao processo de capacitação (VISCONTI et al., 2002).

A concentração de colesterol na membrana plasmática de espermatozoides varia consideravelmente entre as espécies. As razões molares de colesterol e fosfolipídios no espermatozoide de javali são de cerca de 0,20; em espermatozoides de equinos cerca de 
0,36, em espermatozoides de galos 0,30 (PARKS; LYNCH 1992), cerca de 0,40 em espermatozoides de bovinos (PARKS, ARION; FOOTE, 1987), 0,43 em espermatozoides de carneiros (PARKS; HAMMERSTEDT, 1985) e de 0,83 em espermatozoides de humanos (MACK, EVERINGHAM; ZANEVELD, 1986).

Portanto, é possível que a taxa de capacitação espermática relacione-se com a taxa de efluxo de colesterol na membrana plasmática, uma vez que os espermatozoides de espécies com altos teores de colesterol, incluindo o do homem e o do touro, sejam considerados lentos para capacitar ( 8 a 6 h), enquanto que aqueles com menor teor de colesterol como o javali e carneiro são muito mais rápidas (1 a 2 h) (GADELLA et al., 2001).

As espécies reativas de oxigênio (EROs) estão envolvidas no processo de capacitação e na fosforilação dos resíduos do aminoácido tirosina, uma vez que uma baixa produção de EROs é suficiente para que ocorra a geração do cAMP, que irá levar a um aumento da fosforilação do aminoácido tirosina através da estimulação da proteína quinase A (AITKEN ET AL., 1995; LECLERC; de LAMIRANDE; GAGNON, 1997; AITKEN et al., 1998). A presença de resíduos provinientes da fosforilação do aminoácido tirosina em espermatozoides com membrana plasmática intacta podem ser identificados com anticorpos específicos conjugados com um fluoróforo (isotiocianato de fluoresceína FITC) permitindo sua detecção por citometria de fluxo (ANDRADE et al., 2012). Nos últimos anos, muitas evidências surgiram apoiando o papel das espécies reativas de oxigênio (EROs), principalmente do anion superóxido $\left(\mathrm{O}_{2}^{-}\right)$e do peróxido de hidrogênio $\left(\mathrm{H}_{2} \mathrm{O}_{2}\right)$, na função espermática (LECLERC; de LAMIRANDE; GAGNON, 1997). Surpreendentemente, o NO também parece estar envolvido na fisiologia espermática. Baixas concentrações de NO são suficientes para regular a motilidade e proteger a célula espermática contra a ação do ânion superóxido $\left(\mathrm{O}_{2}^{-\bullet}\right)$ que reduz a motilidade. Schaad et al. (1996) relataram que o plasma seminal humano inibe a atividade da óxido nítrico sintase neuronal (nNOS). A relevância fisiológica de tal inibidor da NO endógeno não é clara. É possível que a ejaculação de espermatozóides no aparelho reprodutor da fêmea desencadeie uma reação imune, semelhante à observada durante infecções bacterianas ou transplantes de órgãos. Isto induziria a atividade da óxido nítrico sintase induzível (iNOS) e consequentemente resultaria na geração de grandes quantidades de NO que podem induzir a toxicidade do espermática (ROSSELLI et al., 1995). O plasma seminal pode desempenhar um papel fisiológico na atividade inibidora de NOS (iNOS), mantendo o NO em concentrações baixas, para 
evitar danos tóxicos aos espermatozóides e prevenindo a hiperativação espermática associada ao processo de capacitação (ROSSELLI; KELLER; DUBEY, 1998). A síntese de NO ocorre em vários tipos de células, mediante oxidação da arginina por uma enzima específica chamada óxido nítrico sintase (NOS), cuja atividade depende da calmodulina e do $\mathrm{Ca}^{2+}$ (BREDT; SNYDER, 1990). O NO parece agir através da via AMP cíclico / proteína quinase A (PKA). O mensageiro AMP cíclico estimula a fosforilação do aminoácido tirosina em eventos durante a capacitação, e é concebível, que uma ligação entre NO e a via do AMP cíclico possa explicar o efeito deste radical livre na fosforilação na proteína tirosina. O NO pode causar uma estimulação da proteína quinase A (PKA), através da ativação da monofofato cíclico de guanosina (cGMP) por degradação da via AMP cíclico (HERRERO; de LAMIRANDE; GAGNON, 1999).

Leyton; Saling (1989) forneceram pela primeira vez evidências da presença da fosforilação do aminoácido tirosina em espermatozoides de ratos utilizando o anticorpo anti-fosfotirosina. A fosforilação de proteínas é um evento de modificação póstraducional que funciona como um dos mecanismos reguladores da célula para controlar os vários processos celulares, tais como, o crescimento, o controle do ciclo celular, a montagem do citoesqueleto, a modulação da corrente iônica, e a regulação de receptores (LEYTON; SALING, 1989). Os espermatozoides maduros são células terminalmente diferenciadas e especializadas. Eles são altamente compartimentalizados, mas são desprovidos de qualquer atividade transcricional e traducional. Portanto, isto demonstra a importância de modificações pós-traducionais, como a fosforilação e desfosforilação de proteínas, na regulação de fenômenos importantes como a capacitação espermática, hiperativação e reação acrossômica, que são necessários para o espermatozoide alcançar, ligar, penetrar e fundir-se com o oócito. (NAZ; RAJESH, 2004). O componente da célula espermática que, na maioria das espécies, aparentemente mais sofre fosforilação dos resíduos do aminoácido tirosina é o flagelo (PETRUNKINA et al., 2001).

Visconti et al. (1995) verificaram uma correlação entre o estado de capacitação e o estado de fosforilação dos resíduos do aminoácido tirosina em espermatozoides de ratos. Eles observaram um aumento, tempo-dependente da fosforilação dos resíduos aminoácido tirosina e de um conjunto de proteínas específicas com peso molecular de 40-120 kDa, os quais foram correlacionados com o estado de capacitação dos espermatozoides. Outros estudos relataram um aumento da fosforilação dos resíduos do 
amonoácido tirosina em espermatozoides durante a capacitação em várias espécies, incluindo hamsters (KULANAND; SHIVAJI, 2001), gatos (PUKAZHENTHI et al., 1998), porcos (TARDIF et al., 2001), javali (KALAB et al., 1998), bovinos (GALANTINO-HOMER et al., 2004), equinos (POMMER; RUTLLANT; MEYERS, 2003), macacos (MAHONY; GWATHMEY, 1999), marsupiais (SIDHU et al., 2004) e humanos (LECLERC; de LAMIRANDE; GAGNON, 1996).

A produção excessiva de espécies reativas de oxigênio (EROs) determina o estresse oxidativo, que leva a disfunções na célula espermática através de diferentes mecanismos, como a peroxidação dos lipídeos da membrana plasmática, a inibição do metabolismo, da motilidade e da capacidade fecundante (GUERRA et al., 2004). O evento de peroxidação lipídica surge na presença de espécies reativas de oxigênio (EROs), que ao ter contato com os ácidos docosaexaenoicos da membrana espermática, removem um hidrogênio de uma dupla ligação, transformando-o em radical livre, que por sua vez irá agir em outro ácido docosaexaenoico. Esta reação tem iníco com o sequestro do hidrogênio do ácido graxo polinsaturado da membrana celular. Este sequestro pode ser realizado pelo radical hidroxila $(\mathrm{OH} \bullet)$ ou pelo radical alcoxila $(\mathrm{RO} \bullet)$, formando o radical alquila $(\mathrm{R} \bullet)$. Na primeira equação de propagação, o radical $\mathrm{L} \bullet$ reage rapidamente com o oxigênio $\left(\mathrm{O}_{2}\right)$, resultando em radical peroxila (ROO), que, por sua vez, sequestra novo hidrogênio do ácido graxo polinsaturado, formando novamente o radical L•na segunda equação de propagação. Este processo desencadeia a cascata de peroxidação, causando alterações estruturais na membrana plasmática, com perda de fluidez e da capacidade de regular a concentração intracelular de íons envolvidos no controle do movimento espermático, mudanças no metabolismo celular e, por fim, perda da capacidade de fertilização do espermatozoide (MARQUES et al., 2002).

A peroxidação lipídica pode ser quantificada e localizada após a coloração espermática com a sonda C11-BODIPY581/591. Esta sonda é um análogo dos ácidos graxos poli-insaturados sendo prontamente incorporada à membrana celular. A sua reatividade à peroxidação é comparável a dos ácidos graxos poli-insaturados. Quando intacta esta sonda emite fluorescência vermelha, com comprimento de onda de 580 a $620 \mathrm{~nm}$. Porém, quando sofre peroxidação pelas espécies reativas de oxigênio (EROs), torna-se verde, cujo comprimento de onda é 495 a $545 \mathrm{~nm}$. A alteração da emissão de fluorescência para verde indica a presença de espécies reativas de oxigênio na parte hidrofóbica da bicamada lipídica das membranas espermáticas. Por estas características, esta sonda torna-se uma técnica prática para detectar a peroxidação lipídica, podendo 
ser utilizada na citometria de fluxo ou em outros aparelhos com leitores a laser (SILVA; GADELLA, 2006; ANDRADE et al., 2012).

A reação acrossômica foi descrita pela primeira vez no ouriço e na estrela do mar por Dan $(1952 ; 1954)$. O oócito de todos os mamíferos eutérios é circundado por um revestimento glicoprotéico, a zona pelúcida, que é circundada pelas células da granulosa oriundas do cumulus oophorus recém expandido (YANAGIMACHI, 1994). Antes de fertilizar o oócito, o espermatozoide deve passar pela zona pelúcida e, para isto acontecer, o espermatozoide tem que sofrer a reação acrossômica assim que se ligar à zona pelúcida. A reação acrossômica é um evento irreversível de exocitose, caracterizado por um aumento repentino do influxo de $\mathrm{Ca}_{2}{ }^{+}$para o interior da célula e fusão da membrana acrossomal externa com a membrana plasmática (GADELLA et al., 2001). Após penetrar no cumulus oophorus, o espermatozoide liga-se a zona pelúcida com a membrana plasmática intacta. A ligação do espermatozoide na zona pelúcida ocorre através de receptores para uma glicoproteína (ZP3) localizada na região anterior da cabeça do espermatozoide estimulando a reação acrossômica. (Yanagimachi, 1994). Em revisão recente, Yanagimachi (2011) relatou que em algumas espécies de ouriços do mar (por exemplo, Pseudocentrotus depressus) a reação acrossômica ocorre em um envelope vitelínico muito fino que cobre todo o ovo. Na estrela do mar, a reação acrossômica ocorre na superfície de um revestimento gelatinoso e em algumas espécies de invertebrados como os anelídeos (hydroides hexagonus) a reação acrossômica ocorre na borda externa do envelope vitelínico. No entanto, em mamíferos, os oócitos que estão prontos para fertilizarem são rodeados por um envelope vitelínico espesso chamado de zona pelúcida, que por sua vez é cercada por numerosas células foliculares incorporados em uma matriz acelular (polímeros de ácido hialurónico). Coletivamente, estes são conhecidos como o complexo cumulus oophorus. Ainda existem dúvidas que os espermatozoides apresentem reação acrossômica no momento em que entram na zona pelúcida, entretanto, o local onde os espermatozoides sofrem reação acrossômica ainda é objeto de controvérsia. Yanagimachi; Phillips (1984) ao examinaram complexos cumulus-oócitos coletados de ovidutos de fêmeas acasaladas naturalmente ou inseminadas, encontraram espermatozoides intactos, com acrossomas modificados ou não, dentro do cumulus oophorus podendo este, ser um possível local da reação acrossômal em mamíferos.

Muitos estímulos podem induzir a reação acrossômica, incluindo o cálcio ionóforo A23187, o fluido folicular, a progesterona, e a zona pelúcida (TESARIK, 
1985). No entanto, existem relatos contraditórios na literatura sobre o uso de alguns desses indutores. Por exemplo, alguns autores afirmaram que o cálcio A23187 é capaz de induzir a reação acrossômica em espermatozoides não capacitados. Da mesma forma, outros estudos indicam que os espermatozoides são capazes de responder ao fluido folicular humano (HFF), após um período de três a quatro horas de incubação (de LAMIRANDE; HARAKAT; GAGNON, 1998). Entretanto, Calvo et al.(1989) afirma que seis horas ou mais seriam necessárias para induzir a reação acrossômica. A progesterona foi identificada como um dos reguladores fisiológicos de hiperativação espermática e da reação acrossômica em espermatozoides de humanos (SAGAREPATIL et al., 2012). Os efeitos da progesterona na geração de mensageiros intracelulares, como o diacilglicerol (DAG), são mimetizados pelo ácido $\gamma$ aminobutírico (GABA), sugerindo que possam existir receptores de progesterona do tipo $\mathrm{GABA}_{\mathrm{A}}$ em espermatozoides de mamíferos (SABEUR, 1996). O principal evento de sinalização da progesterona relatado em espermatozoides foi o influxo de cálcio (PUBLICOVER et al., 2008). A alta sensibilidade dos espermatozoides à progesterona pode representar um desafio biológico. Embora as concentrações micromolares de progesterona encontrem-se na vizinhança do cúmulos e do oócito, ela pode se dispersar por difusão passiva e correntes ciliares ao longo do comprimento do trato reprodutor feminino. Assim, se os espermatozoides forem sensíveis a concentrações nanomolares de progesterona, ele pode sofrer hiperativação prematura ou reação acrossômica (CHANG; SUAREZ, 2010; JIN et al., 2011 ).

A capacitação espermática também envolve mudanças no padrão de motilidade, o qual é denominado de hiperativação (Yanagimachi, 1994). Este padrão de motilidade foi identificada por Yanagimachi (1970) em espermatozoides de hamster e é caracterizada por movimentos rápidos e vigorosos da cauda do espermatozoide com a curvatura maior voltada para uma só direção. Isto resulta em um aumento na amplitude do deslocamento lateral da cabeça e em batimentos flagelares assimétricos da cauda do espermatozoide quando em meio viscoso, onde se verifica um padrão de motilidade em formato de estrela ou do tipo circular (WENNEMUTH et al., 2003; CARLSON; HILLE; BABCOCK, 2007; KAULA et al., 2009). Acredita-se que a mensuração da hiperativação sirva como um marcador biológico para avaliar a capacidade funcional do espermatozoide (VERSTEGEN; IGUER-OUADA; ONCLIM, 2002).

A hiperativação deve ter seu início em lugar e momento apropriado para que o espermatozoide consiga realizar a fertilização (SUAREZ, 2008). No entanto, os 
mecanismos exatos que levam a ativação da hiperativação não são conhecidos. Marquez e Suarez (2007) descreveram que o aumento do pH é o elemento chave para a sinalização e controle do $\mathrm{Ca}_{2}{ }^{+}$, e isso altera o padrão do batimento flagelar. Para Lamirande, Leclerc; Gagnon (1997) o influxo de íons bicarbonato é o que determina o desenvolvimento da motilidade hiperativada. Porém, sabe-se que o cálcio $\left(\mathrm{Ca}_{2}{ }^{+}\right)$é o segundo mensageiro primário que desencadeia a hipermotilidade (SUAREZ, 2008).

Um fator importante para hiperativação são os canais de $\left(\mathrm{Ca}^{2+}\right)$ espermatozoideespecíficos (CatSper). Estes canais são constituídos por quatro subunidades proteicas (CatSpers 1 - 4). O canal CatSper se abre em resposta a alcalinização intracelular, permitindo o influxo de $\mathrm{Ca}^{2+}$ através da membrana do espermatozoide, sendo possível que o influxo de $\mathrm{Ca}^{2+}$ induza diretamente a hiperativação ou desencadeie a liberação de cálcio de reservas internas, através da liberação de cálcio induzido por segundo mensageiro (HINRICHS; SHAVAHN; LOUX, 2012).

O movimento característico apresentado pela célula espermática durante o fenômeno da hiperativação pode ser detectado pelas análises computadorizadas da motilidade (CASA - Computer Assisted Sperm Analysis). Este padrão de movimento é representado pelo aumento do ALH (amplitude do deslocamento lateral da cabeça) e do VCL (velocidade curvilinear) e uma redução da LIN (Linearidade) (VERSTEGEN; IGUER-OUADA; ONCLIM, 2002).

\subsection{CAPACITAÇÃO, REAÇÃO ACROSSÔMICA E HIPERATIVAÇÃO NO ESPERMATOZOIDE EQUINO}

A capacitação espermática é um acontecimento necessário para que o ocorra o processo de fertilização. Entretanto, apesar das inúmeras pesquisas realizadas no decorrer dos anos, ainda é um evento que não se encontra completamente elucidado (VISCONTI et al., 2005).

Todavia, apesar das bases moleculares que envolvem a capacitação espermática ainda permanecerem sobre investigação, salienta-se, que este processo, está associado com a presença do bicarbonato e com o aumento dos níveis de AMP cíclico intracelular gerados pela adenil ciclase (AC). O AMP ciclíco ativa a proteína quinase A (PKA), que por sua vez induz a fosforilação do aminoácido tirosina (VISCONTI et al., 1998). 
Entretanto, se houver qualquer inibição da $\mathrm{AC}$ e / ou da sinalização da PKA, a fosforilação da tirosina é abolida e a capacitação espermática não acontecerá (VISCONTI et al., 2005).

Para testar o papel do AMP cíclico como um mediador chave da fosforilação do aminoácido tirosina em espermatozoides de equinos, McPartlin et al. (2008) demonstraram que espermatozoides incubados por um período de 4 a $6 \mathrm{~h}$ em meio Whitten modificado (MW) com a adição de bicarbonato $\left(\mathrm{HCO}_{3}{ }^{-}\right)$e de BSA produziram altas taxas de fosforilação do aminoácido tirosina. Por outro lado, quando incubados com um análogo do AMP cíclico o dibutiril AMP cíclico (dbAMP cíclico) e um inibidor da fosfodiesterase, 3-isobutil-1-metilxantina (IBMX) no mesmo meio, porém, em condições não capacitantes (desprovido de albumina e BSA e / ou o bicarbonato), não induziu a fosforilação dos resíduos do aminoácido tirosina.

Acredita-se que os espermatozoides de equinos sejam capacitados lentamente devido ao alto conteúdo de colesterol em sua membrana plasmática e que o plasma seminal destes animais, que apresenta vesículas ricas em colesterol (protossomas) secretadas pela próstata bloqueiam o efluxo do colesterol da membrana plasmática ajudando, provavelmente, a retardar a capacitação (GADELLA; EVANS, 2011). Entretanto as tentativas de capacitar o espermatozoide equino in vitro têm permanecido inconclusivas, como foi demonstrado pelos baixos níveis de fosforilação dos resíduos do aminoácido tirosina (POMMER; RUTLLANT; MEYERS, 2003), as baixas taxas de exocitose acrossomal (RATHI et al., 2003), e as baixas taxas de fertilização in vitro (FIV) (ALM et al., 2008). Por outro lado, apesar dos baixos níveis de fosforilação dos resíduos do aminoácido tirosina, McPartlin et al. (2008) apoiam a ideia de que este evento seja um marcador da capacitação no espermatozoide equino, uma vez que isto também é demonstrado em outras espécies.

A estrutura da célula espermática a torna potencialmente susceptível a espécies reativas de oxigênio (EROs). A membrana espermática é rica em ácidos graxos poliinsaturados e pode facilmente ser submetida a peroxidação lipídica, na presença de EROs, levando a alterações na fluidez da membrana evoluindo para uma redução da capacidade fertilizante. Os espermatozóides de equinos produzem EROs (BALL; VO; BAUMBER, 2001). Sob condições fisiológicas, a baixa produção de EROS é estimulada na presença de cálcio. Esta baixa produção pelo espermatozoide equino é importante na indução de capacitação, com um concomitante aumento na fosforilação doaminoácido tirosina (BAUMBER et al., 2003). No entanto, um desequilíbrio entre a 
produção e a remoção destas EROs podem levar a peroxidação nas membranas celulares e danos aos ácidos nucléicos (BOX et al., 1995).Os produtos finais da peroxidação lipídica, tais como, substâncias reativas ao ácido tiobarbitúrico (TBARS) ou 4hidroxinonenal (4-HNE derivado dos ácidos graxos poliinsaturados que podem, nos processos celulares, ligarem-se aos resíduos de aminoácidos, principalmente da lisina, produzindo modificações das cargas na superfície das lipoproteínas) (ABDALA; SENA, 2008), também exercem efeitos tóxicos e podem diminuir a motilidade dos espermatozóides (ALVAREZ; STOREY, 1982). Estes produtos podem servir como indicadores bioquímicos da peroxidação lipídica. Em espermatozoides de equinos o BODIPY-C 11 é utilizado para avaliar a suscetibilidade dos espermatozoides a diferentes insultos oxidativos (BAUMBER et al., 2000; FERRUSOLA et al., 2009b, BALÃO DA SILVA et al., 2011; ANDRADE et al., 2012).

Balão da Silva et al. (2011) descreveram a melatonina como um potente antioxidante em espermatozoides de equinos. Verificaram que este hormônio teve um efeito significativo na redução da peroxidação lipídica após 3h de incubação, nas concentrações utilizadas (50, 100, 200 pM e $1 \mu \mathrm{M})$. Por outo lado, Casao et al. (2010) sugerem que a melatonina pode estimular ou inibir a capacitação espermática (avaliada utilizando o ensaio de clortetraciclina), de uma forma dependente da dose (200 pM), concluindo, que doses mais baixas de melatonina reduz as espécies reativas de oxigênio (EROs) e estimula a capacitação, enquanto que doses mais elevadas de melatonina agiriam removendo os oxidantes do meio evitando a capacitação.

Samper et al. (1989) estudando a possibilidade de determinar se espermatozoides equinos poderiam ser capacitados em meio Tyrode's, livre de cálcio e se o período de incubação seria necessário para induzir a reação acrossômica e a penetração em oócitos desnudos de hamsters verificaram que com o decorrer do tempo de incubação $(0,2,4,6$, 8 e $10 \mathrm{~h}$ ) ocorreu um aumento significativo da porcentagem de células com acrossoma reagido e que os espermatozoides não penetraram os oócitos desnudos no tempo $0 \mathrm{~h}$, indicando que a incubação é necessário para que ocorra a capacitação in vitro.

Rathi et al. (2001) objetivaram estabelecer uma técnica para a citometria de fluxo afim de determinar o status de capacitação em espermatozoides de garanhão. Detectaram que o uso da merocianina 540 e de uma aglutinina de Arachis hypogea (amendoim) conjugada ao isotiocianato de fluoresceína (FITC-PNA) apresentaram-se melhores que os ensaios com a clortetracilina (CTC) por serem mais precisos do que os ensaios realizados com a técnica de microscopia de fluorescência. Além disso, 
identificaram que o $\mathrm{Ca}^{2+}$ ionóforo não poderia induzir a reação acrossômica na ausência de bicarbonato. A coloração da CTC, para detecção das alterações do estado de capacitação, se igualou a merocianina 540 somente quando $\mathrm{Ca}^{2+}$ ionóforo foi incluído no meio de incubação, caso contrário, a CTC seria muito lenta para detectar alterações da membrana plasmática.

No mesmo experimento Rathi et al. (2001) identificaram que a hiperativação não é um parâmetro adequado para estimar com precisão a porcentagem de células capacitadas, já que em seus resultados apenas poucos espermatozoides incubados em diferentes tempos em meio de capacitação rico em bicarbonato e $\mathrm{Ca}^{2+}$ apresentaram esta característica.

Segundo Yanagimachi, (1994) um dos primeiros eventos a ser estabelecido como um sinal de que a célula espermática está em direção à capacitação é a hiperativação. McPartlin et al. (2009) verificaram que a adição de procaína (5 mM) no meio de capacitação de espermatozoides equinos provocou uma mudança imediata na motilidade (movimento circular em forma de estrela), caracterizado como padrão de hiperativação. Tendo conhecimento que a procaína induz a hiperativação por aumentar a permeabilidade da membrana plasmática pelo cálcio e que a reação acrossômica é

dependente de $\mathrm{Ca}^{2+}$ para que ocorra o evento de exocitose, os autores identificaram que a indução da hiperativação pela procaína é independente do evento de reação acrossomal, suportando a hipótese de que provavelmente os caminhos que regulam a capacitação e a hiperativação são separáveis e independentes.

\section{3 ÓXIDO NÍTRICO}

Os primeiros trabalhos realizados excluindo a possibilidade de compostos tais como o nitrato $\left(\mathrm{NO}_{2}\right)$, nitrito $\left(\mathrm{NO}_{3}\right)$, amônia $\left(\mathrm{NH}_{3}\right)$, e hidroxilamina como fonte de $\mathrm{NO}$ foram realizados por Palmer e Moncada em 1989. Antes disso, em 1988, o aminoácido L-arginina foi identificado como um fator de relaxamento derivado do endotélio vascular que induzem a vasodilatação (EDRF) (MONCADA; PALMER; HIGGS, 1991).

O NO é uma molécula simples, gasosa, incolor à temperatura e pressão ambiente, que pode ter diversas funções, incluindo ser um segundo mensageiro 
intercelular, bem como um mensageiro intracelular (substâncias parácrinas e autacoides). Tem uma meia vida curta que é atribuída, muitas vezes, por uma rápida oxidação a nitrato $\left(\mathrm{NO}_{2}{ }^{-}\right)$e nitrito $\left(\mathrm{NO}_{3}{ }^{-}\right)$, apresentando solubilidade máxima em água e sendo bem semelhante ao oxigênio puro. A molécula de NO é considerada não polar e se difunde livremente através das membranas, além de ser uma espécie paramagnética, ou seja, apresenta elétrons desemparelhados (STAMLER; SINGEL; LOSCALZO, 1992).

Vários métodos são descritos na literatura para a detecção da produção de NO. Por exemplo: a mensuração da NOS através da conversão do carbono $14\left({ }^{14} \mathrm{C}\right)$ da Larginina para L-citrulina $\left({ }^{14} \mathrm{C}\right)$ (BREDT; SNYDER, 1989), a partir da detecção dos subprodutos finais do $\mathrm{NO}$, tais como $\mathrm{NO}_{2}{ }^{-} \mathrm{e} \mathrm{NO}_{3}{ }^{-}$, spin-trapping (técnica analítica para detectar radicais livres), técnicas combinadas com elétron de ressonância paramagnética (EPR), a espectroscopia (KOMAROV et al., 1993), ou pode também ser detectado e medido indiretamente utilizando-se a sonda fluorescente 4,5-diacetato diaminofluorescein-2/diacetato (DAF) (LAMPIÃO; STRIJDOM; DU PLESSIS, 2006).

A maioria das funções fisiológicas do NO parece ser mediada pela ativação do seu receptor intracelular, a guanilato ciclase (GC) (DE VERA et al., 1996; WEINBERG et al., 1995). Através da nitrosação do radical heme, o NO aumenta a atividade da GC (MURAD et al., 1990; IGNARRO, 1991), sob condições patológicas, quando grandes quantidades de NO são produzidas e outras reações tornam-se mais predominantes. Entre elas, pode-se citar às interações do NO com centros de ferroenxofre, tióis de proteínas, lipídios, e com o zinco em importantes moléculas celulares (HOBBS, 1997).

O NO é um importante mensageiro intercelular nos mamíferos. O mecanismo de sinalização intercelular é, em geral, realizado através de receptores de membrana celular na célula alvo. Estes receptores são, habitualmente, transmembranosos tendo contato com citoplasma e desencadeando uma "cascata" de sinais intracelulares que finalizarão em uma mudança na célula. Pelas suas características químicas de alta difusibilidade, a sinalização do NO pode ser exercida diretamente em nível intracelular, sem receptores transmembranosos. Devido à sua penetração intracelular sem intermediários membranosos, o organismo utiliza o NO em funções fisiológicas em que é necessária uma resposta rápida (FLORA FILHO; ZILBERSTEIN, 2000). O NO está envolvido em uma série de eventos biológicos, como na regulação do tônus vascular (IGNARRO, 1989), no processo de inflamação (WINK; MITCHELL, 1998), no sistema 
cardiovascular (melhorandoa oferta de sangue para o músculo cardíaco) (LOSCALZO; WELCH, 1995; PFEIFFER; MAYER; HEMMENS, 1999), na desagregação plaquetária (AZUMA et al., 2012; RODOMSKI et al., 2012), e na comunicação neuronal (GARTHWAITE; GARTHWAITE, 2006). Além disso, ele desempenha um papel significativo em processos reprodutivos, como mediador da função espermática (HERRERO; GAGNON, 2001) e no controle do fluxo sanguíneo do corpo cavernoso do pênis, explorando drogas anti-impotência como o Viagra (RAND; LI, 1995; PFEIFFER; MAYER; HEMMENS, 1999). No entanto, o NO pode vir a ter um papel catastrófico e até fatal nos casos de choque séptico, onde a síntese de NO é induzida exessivamente nos vasos sanguíneos resultando em derrame vascular e queda da pressão arterial, nos casos de artrite reumatóide vindo contribuir para a lesão do tecido causado por uma resposta inflamatória inadequada e nos caso de acidente vascular cerebral contribuindo para danos cerebrais. Atualmente as pesquisas estão em direção de encontrar inibidores específicos da síntese de NO que possa limitar esta superprodução (PFEIFFER; MAYER; HEMMENS, 1999)

Em espermatozoides, o NO parece desempenhar um papel importante na regulação da motilidade e na capacitação espermática (HELLSTROM et al., 1994; LEWIS et al., 1996). Este envolvimento do NO ocorre através da ativação da guanilato ciclase (GC), uma enzima que catalisa a reação de guanosina triposfato (GTP) em monofosfato cíclico de guanosina (GMPc) (IGNARRO et al., 1981). A importante interrelação do NO e do monofosfato ciclico de guanosina (GMPc) que começou em meados de 1970 foi com o tempo sendo compreendido como um importante sinal do sistema de tradução (IGNARRO et al., 1981). DeGuchi; Yoshiaka (1982) trabalhando com preparações de cérebro e culturas de neuroblastomas encontraram substâncias que poderiam ativar a GMPc. Este material endógeno foi identificado como L-arginina. A ativação da GMPc pela L-arginina foi similar em muitos aspectos para a ativação observada em vários nitrovasodilatadores. Hibbs; Taintor; Vavrin (1987) em estudos com macrófagos de murinos verificaram a formação de $\mathrm{NO}_{2}{ }^{-}$e $\mathrm{NO}_{3}{ }^{-}$e o aparente precursor desta síntese foi a L-arginina. Além disso, os análogos da L-arginina tal como $\mathrm{N}^{\mathrm{G}}$-nitro-1-arginina metil éster (L-NAME) bloqueavam esta via. Preparações de amostras com tecido endotelial demonstraram que um dos nitrogênios guanidinos da Larginina foram oxidados e convertidos em NO, tendo ainda um outro produto da reação, a L-citrulina, sendo catalizada pelas NOS (MURAT, 1994). Portanto, o NO é sintetizado a partir da L-arginina através da enzima (NOS) (PALMER et al., 1988). Esta 
reação requer uma série de cofatores, como a adenina b-nicotinamida dinucleotidiofosfato (NADPH), mononucleotídio flavina, flavina-adenina-dinucleotídio, tetrahidrobiopterina, bem como a calmodulina e o cálcio (MONCADA; HIGGS, 1993). $\mathrm{O}$ oxigênio $\left(\mathrm{O}_{2}\right)$ molecular também é utilizado nesta reação que prossegue através da síntese do intermediário N-hidroxiarginina resultando na formação da L-citrulina (HERRERO; GAGNON, 2001). São descritas três isoformas de NOS, baseando-se em sua origem tecidual, função e propriedades estruturais (DIXIT; PARVIZI, 2001). Duas destas são do tipo constitutivas dependes de cálcio: a neuronal (nNOS) e a endotelial (eNOS). A terceira tipo é induzível (iNOS) e cálcio independente (MONCADA; PALMER; HIGGS, 1991). Estas isoformas estão distribuídas em diversos tipos celulares e tecidos. Além disso, uma célula pode expressar mais de uma isoforma de NOS (MEHTA et al., 1995).

A óxido nítrico sintase neuronal (nNOS) foi a primeira isoenzima a ser purificada (BREDT; HWANG; PSNYDER, 1990) e clonada (BREDT et al., 1991). É cálcio $\left(\mathrm{Ca}^{2+}\right)$ e calmodulina dependente sendo expressa em elevadas concentrações no cérebro (MONCADA, 1994). Pode também ser encontrada em músculos esqueléticos (WEINER et al., 1994) e células $\beta$ do pâncreas (SCHIMIDT et al., 1992). A óxido nítrico sintase endotelial (eNOS) funcionalmente é semelhante com a nNOS, por ser $\mathrm{Ca}^{2+}$ e calmodulina dependente. Seu gene é conservado entre as espécies (VENEMA et al., 1994) e é altamente expressa em células vasculares endoteliais (DIXIT; PARVIZI, 2001). A óxido nítrico síntase induzível (iNOS) é produzida por muitos tipos celulares e tecidos, após serem expostos a citocinas e produtos bacterianos, sendo $\mathrm{Ca}^{2+} \mathrm{e}$ calmodulina independente (STUEHR et al., 1991).

\section{4 ÓXIDO NÍTRICO E O ESPERMATOZOIDE}

Antes de 1996, não havia nenhuma evidência que os espermatozoides poderiam gerar NO. No entanto, Herrero et al. (1996) e Lewis et al. (1996) demonstraram que a NOS estava presente em espermatozoides de ratos e de humanos, sugerindo um papel importante do NO na manutenção da motilidade dos espermatozoides. No rato, por exemplo, NOS foi observada no acrossoma e na cauda de espermatozoides não capacitados, sua identificação na cabeça do espermatozoide desapareceu com o tempo, 
quando incubados sob condições de capacitação (HERRERO et al., 1996). Em contraste, em espermatozoides de humanos, a marcação específica para nNOS e eNOS foi observada no segmento pós-acrosomal e equatorial, mas não sobre o flagelo. O NO é capaz de estimular a adenil-ciclase (AC) (HERRERO et al., 2000) e aumenta a fosforilação do aminoácido tirosina (BAKER; AITKEN, 2004), os dois passos críticos da regulação da fisiologia espermática (FERRUSOLA et al., 2009a).

A presença de NOS em espermatozoides equinos in natura e criopreservados foi relatada pela primeira vez por Ferrusola et al. (2009a). Os autores detectaram a NOS na cabeça do espermatozoide, na região pós-acrossomal, e na peça intermediária. Neste experimento os autores encontraram correlações significativas entre a produção de NO e algumas características do sêmen pós-descongelação relacionadas com a qualidade do espermatozoide, como a integridade de membrana e principalmente com os padrões de motilidade. Em relação a isto, foi observada uma variação significativa de garanhão para garanhão no tocante a produção de NO, onde a criopreservação poderia estar induzindo esta produção. Curiosamente, ainda neste experimento, Ferrusola et al. (2009a) perceberam que a gema de ovo foi capaz de remover a maior parte do NO produzido pelos espermatozoides equinos, sugerindo, desta forma, que a gema de ovo deva ser removida de amostras criopreservadas antes da inseminação artificial para promover a sobrevivência dos espermatozoides e, talvez, aumentar a fertilidade.

O NO tem sido demonstrado como um modulador da motilidade in vitro, da viabilidade espermática, da reação acrossomal e do metabolismo de espermatozoides em várias espécies de mamíferos. Entretanto, o mecanismo ou os mecanismos que influenciam estas funções no espermatozoide ainda não estão claros (REVELLI et al., 2001). Estudos in vitro têm demonstrado que as baixas concentrações de NO aumentam a motilidade espermática no rato (HERRERO; CEBRAL; BOQUET, 1994), no hamster (YEOMAN et al., 1998) no humano (HELLSTROM et al., 1994; ZHANG; ZHENG 1996) e a reação acrossomal de espermatozoides de ratos (HERRERO et al., 1997) e de touros (ZAMIR et al., 1995) auxiliando, desta forma, a ligação do espermatozoide com a zona pelúcida (SENGOKU et al., 1998) Deste modo, a motilidade espermática é inibida pelo inibidor da NOS, $\mathrm{N}^{\mathrm{G}}$-nitro- L -arginina metil éster (L -NAME) (LEWIS et al., 1996) e pelo removedor de NO, o azul de metileno (DONNELLY et al., 1997).

Rosselli et al. (1995) procurando evidências de que o NO diminui a motilidade e induz a toxicidade espermática verificaram que este radical livre pode causar toxicidade 
espermática quando em alta concentração, bem como, inibir a motilidade em espermatozoides de humanos.

O papel do NO na fisiologia espermática de mamíferos parece paradoxal, baixos níveis de NO são benéficos, enquanto altos níveis de NO parecem ser prejudiciais (VIGNINI et al., 2006) podendo afetar sua função e fertilidade (RADI, 2004). Todavia, isso ocorre quando combinado com o radical superóxido produzindo peroxinitrito, que por sua vez, pode reagir rapidamente com proteínas, lipídios e ácidos nucléicos (RADI, 2004).

\subsection{L-ARGININA: PRECURSORA DO ÓXIDO NITRÍCO}

O aminoácido L-arginina é conhecido como um importante regulador na comunicação celular em uma série de eventos fisiológicos e patológicos (PALMER; MONCADA, 1989). A L-arginina desempenha uma atividade de suma importância na motilidade espermática de seres humanos, coelhos, bovinos e bodes em condições in vitro (KELLER; POLAKOSKI, 1975; RADANY; ATHERTON; FORRESTER, 1981; PATEL et al., 1998; MEISER; SCHULZ, 2003). No entanto, os dados se tornam escassos quando nos referimos a espermatozoides equinos.

Alguns dos aminoácidos detectados no plasma seminal desempenham um papel importante no metabolismo dos espermatozoides e na motilidade (GASSNER; HOPWOOD, 1952). Um deles é o aminoácido L -arginina, que é muitas vezes referido como um aminoácido não essencial. A L-Arginina participa na formação dos espermatozoide e é um componente básico encontrado na nucleoproteína dos espermatozoides de várias espécies (MIROUEH, 1970 ).

Se por um lado a L-arginina é uma chave importante para motilidade de várias espécies, por outro lado, vem sendo enfatizado seu papel na indução da capacitação e da fosforilação do aminoácido tirosina em espermatozoides (ROY; ATREJA, 2007). A Larginina é descrita como um substrato para a enzima óxido nítrico sintase (NOS) produzir óxido nítrico (NO) (MONCADA; PALMER; HIGGS, 1991) que, por sua vez, atua como antioxidante e induz a uma variedade de mensagens inter e intracelulares (DIXIT; PARVIZI, 2001). Em espermatozoides de humanos, o NO é um importante agente para a fertilização do oócito agindo como mensageiro celular, modulando o 
AMP cíclico envolvido na capacitação e na fosforilação do aminoácido tirosina (HERRERO et al., 2000). Em espermatozoides do epidídimo de hamsters, o NO apresenta-se como uma peça importante para a motilidade e hiperativação (RICHARD et al., 1998). Em espermatozoides de bovinos, a L-arginina atua como protetora espermática contra peroxidação da membrana plasmática (SRIVASTAVA et al., 2000; O'FLAHERTY; RODRIGUEZ; SRIVASTAVA, 2004). A deficiência de L-arginina provoca um desarranjo no metabolismo espermático podendo levar a redução da motilidade (KELLER; POLAKOSKI, 1975; SRIVASTAVA et al., 2006 ), disfunção da espermatogênese (SRIVASTAVA et al., 2006) além de aumentar a produção de EROs quando em grande concentração (GROSS; WOLIN, 1955). A relevância bioquímica e fisiológica da L-arginina é descrita no aparelho reprodutor do macho, sendo utilizada com sucesso, no tratamento de algumas doenças reprodutivas (MÉNDEZ; HERNÁNDEZ, 1993). Estudos em humanos oligospérmicos e astenospérmicos evidenciaram uma melhora na motilidade e na concentração espermática de pacientes submetidos a tratamentos com L-aginina (DAVID; POLAKOSKI, 1975; SRIVASTAVA; AGARWAL, 2010).

Segundo Holt; Albanesi (1994) demonstraram uma correlação entre a deficiência de L -arginina e a perda da função normal dos testículos. A L-arginina é conhecida por aumentar a espermatogênese e age como uma fonte de energia para a motilidade espermática na forma de ácido fosfórico. Radany; Atherton; Forrester (1981) sugeriram que a L-arginina e seus análogos (L-lisina e L-ornitina) mostram o papel ativo do grupo guanidino no tranporte da L-arginina através da célula espermática.

Provavelmente, concentrações elevadas de L-arginina (40-50 mM), devido a uma maior concentração de NO produzido pela própria L-arginina pode tornar os espermatozoides imóveis (O’FLAHERTY; RODRIGUEZ; SRIVASTAVA, 2004). Esta conclusão é apoiada pela observação feita por Rosselli et al. (1995), em que concentrações elevadas de NO diminui a motilidade e induz toxicidade em espermatozoides humanos. Outra razão plausível para a redução da motilidade pode estar relacionada com as baixas concentrações de AMP cíclico em relação a concentrações mais elevadas de $\mathrm{NO}$, um requisito importante para os mecanismos de motilidade.

O’Flaherty; Rodriguez; Srivastava, (2004) observaram que a adição de Larginina na concentação de $10 \mathrm{mM}$, manteve a motilidade de espermatozoides criopreservados de bovinos inalterada, por outro lado, quando aumentava-se essa 
concentração para 20, 40 e $50 \mathrm{mM}$ havia redução desta motilidade. Verificaram também, que quando os espermatozoides foram incubados com $\mathrm{L}$-arginina $(10 \mathrm{mM})$ na presença de dois inibidores de NOS (L -NA e L -NAME; $1 \mathrm{mM}$ ) houve uma inibição significativa da capacitação. Uma inibição semelhante foi observado para a reação acrossômica induzida por L-arginina. Roy e Atreja (2008) sugerem que a L-arginina (10 $\mathrm{mM}$ ) induz a capacitação, ou seja, uma baixa concentração de NO é necessária para induzir a capacitação e a fosforilação do aminoácido tirosina em espermatozoides de búfalo.

\subsection{INIBIDORES DO ÓXIDO NITRÍCO}

Os inibidores da síntese do NO atuam competitivamente pelo mesmo sítio de ação do aminoácido L-arginina (WENDY et al., 2001). A concorrência entre inibidor e substrato para a absorção celular pode representar um importante mecanismo de inibição para diminuir a disponibilidade de L-arginina para a NOS (BOGLE et al., 1992)

O 7-nitroindazole, um inibidor do NOS reduz o fluxo de sangue cerebral (KELLY; RITCHIE; ARBUTHNOTT, 1995) confirmando a importância de nNOS na regulação do tônus vascular dentro do cérebro (AYAJIKI; OKAMURA; TODA, 1993). A ação seletiva do 7-nitroindazole na nNOS in vivo sugere que ele possa ser uma ferramenta poderosa para a investigação dos papéis fisiológicos e patológicos do NO gerado por esta isoforma (MOORE et al., 1993). A inibição de NOS pelo 7nitroindazole provavelmente é multifacetada, uma vez que se liga ao grupo heme da Larginina e da tetrahidrobiopterina $\mathrm{BH} 4$ (cofator para síntese de NO) de forma reversível (MAYER et al., 1994).

A dimetilarginina assimétrica (ADMA) é um inibidor potente de todas as isoformas de NOS e é encontrado in vivo em vários órgãos e tecidos, incluindo o cérebro, rim e no plasma. Além disso, este composto se acumula nos estados de doença associados com a homeostase, doenças cardiovasculares, insuficiência renal e hipercolesterolemia (VALLANCE et al., 1992)

Os derivados da L-citrulina também inibem a síntese de NO através da ligação na porção heme da enzima (JOLY et al., 1995). A S-metil-L-tiocitrulina (SMTC) é um 
inibidor não seletivo da NOS, mas os seus derivados, S-metilo e S-etílicos são inibidores das eNOS, nNOS e iNOS in vitro (FURFINE et al., 1994)

A $\mathrm{N}^{\mathrm{G}}$-monometil-L-arginina (L-NMMA) pode ser metabolizada pela NOS, obtendo-se N-metil-N-hidroxi-L arginina, que parece estar associada a uma inativação irreversível da enzima (FELDMAN et al., 1993). Segundo Palmer; Moncada (1989) o (L-NMMA), um análoga da L-arginina, é um inibir competitivo da síntese da NOS em células endoteliais. O L-NMMA já foi utilizado para avaliar o papel da L-arginina em resposta à vasodilatadores em aorta de ratos (MONCADA; PALMER; HIGGS, 1991), artéria cerebrais de caninos (KATUSIC et al., 1993), e nas artérias e veias humanas (YANG et al., 1990). O N-iminoetil-L-ortinina (L-NIO), $\mathrm{N}^{\mathrm{G}}$-nitro-L-arginina (L-NA) e $\mathrm{N}^{\mathrm{G}}$-nitro-L-arginina-metil-ester (L-NAME) são todos análogos da L-arginina e assim como o L-NMMA inibem a geração do NO (REES et al., 1990).

Moore et al. (1990) descreveram que em tecidos aórticos de coelhos, o L-NA foi seis vezes mais eficaz que o L-NMMA no bloqueio da vasodilatação destes tecidos. Outros estudos, como o de Gross et al. (1990) verificaram que o L-NA é100 vezes mais potente do que o L-NMMA no bloqueio da síntese de NO endotelial. Em contraste LNA é substancialmente menos eficaz do que o L-NMMA na inibição de NO em macrófagos (GROSS et al., 1990).

Em um experimento o L-NAME inibiu de forma muito eficiente o acúmulo de nitrito, em uma linhagem de células de câncer de mama de murinos (CENDAN et al., 1996). Além disso, é conhecido por suprimir os efeitos benéficos da bradicinina em corações com isquemia durante a recuperação pós-isquêmica do miocárdio (ZHU et al., 1995).

Donnely et al. (1997) avaliaram a influência da NOS na estimulação e inibição da motilidade em espermatozoides de humanos. Utilizando inibidores da NOS no meio de incubação de espermatozoides, relataram que o L-NAME apresentou-se como um excelente inibidor da NOS deprimindo a motilidade. Por outro lado, o L-MMA e L-NA foram menos efetivos na inibição da NOS sugerindo a presença da NOS em espermatozoides de humanos. Herrero; Gagnon (1991) observaram em espermatozoides humanos que o L-NAME e 7-nitroindazol não alteraram a reação acrossômica. No entanto, a presença do L-NAME com 7-nitroindazole, na mesma amostra reduziu a reação acrossomal. Eles também verificaram que L -NAME provocou uma diminuição no nível de fosforilação dos resíduos do aminoácido tirosina. 
Para saber se o efeito da L-arginina na capacitação espermática e na reação acrossômica de bovinos foi mediada pela NOS, O'Flaherty; Rodriguez; Srivastava (2004) verificaram, que quando os espermatozoides foram incubados com L -arginina (10 mM) na presença de dois inibidores de NOS ( L -NA e L-NAME) houve uma inibição significativa de capacitação e da reação acrossômica .

A L-arginina com o seu efeito mediado pelo NO induz a capacitação espermática em espermatozoides de búfalos, porém, se neste momento houver a presença de L-NAME, este evento provavelmente será inibido (ROY; ATREJA, 2007). O L-NAME diminui a motilidade progressiva de espermatozoides de touros após $3 \mathrm{~h}$ de incubação. Por outro lado, a L-arginina reverte este efeito (LEAL et al., 2009).

\subsection{REMOVEDORES (SCAVENGERS) DO ÓXIDO NITRÍCO}

Os primeiros removedores fisiológicos de EROs descritos no sêmen foram a catalase (BALL et al., 2000; BAUMBER; BALL, 2005), um removedor do peróxido de hidrogênio (ZINI; de LAMIRANDE; GAGNON, 1995); a superóxido dismutase, um removedor para o ânion superóxido (SOD) e a glutationa peroxidase (GPx). (BALL, 2008). Entretanto, parece que há certa variação relacionada à quantidade e importância dessas enzimas removedoras de NO, no sêmen entre as espécies. Por exemplo, no equino as concentrações encontradas são: catalase $(98,7 \pm 29,2$ U / mg proteína), SOD $(29,15 \pm 6,64 \mathrm{U} / \mathrm{mg}$ proteína) e GPx $(0,87 \pm 0,06 \mathrm{mM} \mathrm{NADPH}$ oxidado/min/ mg/ de proteína) indicando que o plasma seminal equino apresenta uma maior atividade da catalase e da SOD (BALL, 2008).

Zini, de Lamirande, e Gagnon (1995) descreveram que a enzima SOD não influenciou a hiperativação e não promoveu a capacitação espermática em humanos quando na presença de NONOatos (compostos que liberam o NO no meio de incubação). Sugerindo que provavelmente o NO possa induzir a capacitação independente da produção de SOD.

O azul de metileno parece inibir a estimulação do NO via guanilato ciclase (GC) e tem sido amplamente utilizado para a inibição de guanilato monofostato ciclíca (GMPc). Ele é conhecido por afetar as enzimas que contém ferro (SAIARIS; BABBS; VOORHEES, 1991) presentes na GC e NOS (GERZER HOFMANN; SCHULTZ, 
1981). O grupo heme da GC tem sido sugerido como um local alvo do azul de metileno (MURAT et al., 1978). Ele parece atuar como inibidor dos nitrovasodilatadores em células (MURAT et al., 1978), bem como bloqueando o relaxamento da musculatura lisa (GRUETTER et al., 1979).

O’Flaherty; Rodriguez; Srivastava, (2004) descreveram que a capacitação e a reação acrossômica de espermatozoides de bovinos são bloqueadas quando no meio de incubação é adicionado o azul de metileno.

Espermatozoides humanos incubados com azul de metileno apresentaram uma diminuição tempo-dependente na produção de NO, afetando a motilidade progressiva e reduzindo vários padrões de motilidade (VAP, VCL, VSL, ALH e LIN). A viabilidade espermática (integridade de membrana) permaneceu inalterada após tratamento com azul de metileno (dados não demonstrados), ilustrando que seu uso não foi tóxico para os espermatozóides, apesar da redução na motilidade (DONNELY et al.,1997). Rodriguez et al. (2005) observaram que a adição do azul de metileno reduziu significativamente os níveis de reação acrossômica em espermatozoides de bovinos.

A curcumina (diferuloyl metano, CAS 458-37-7) é um pigmento presente nos rizomas de Curcuma longa um tempero muito utilizado na culinária indiana (AMMON; WAHL, 1991). Ela possui muitas propriedades terapêuticas, incluindo atividades antiinflamatórias e anticancerígenas. A curcumina inibe a formação de nitrito por competir com o oxigênio para reagir com o NO (SRIMAL, 1987). Foi relatado que a curcumina inibe a geração de NO a partir da ativação de macrófagos. Esta inibição pode ser um resultado da eliminação do NO pela curcumina (JOE; LOKESH, 1994).

Os flavonóides são compostos naturais utilizados para o tratamento de lesão do endotelial vascular. Eles são conhecidos por serem excelentes removedores dos radicais livres (VANACKER et al., 1995). Maeda et al. (1994) demonstraram que o removedor 2-fenil-4,4,5,5-tetrametilimidazoline (PTIO), aumenta a permeabilidade vascular em tumores sólidos sendo mediado pelo NO. O ginkgo biloba (EGb 761) é um removedor do NO. Ele compete com a oxi-hemoglobina para gerar uma reação com NO durante a interação do complexo I da catalase. É considerado um importante agente terapêutico em condições em que a produção de NO está alterada (MARCOCCI et al., 1994). Os radicais removedores do NO (quelantes de ferro e derivados de vitamina E), são agentes terapêuticos neuroprotetores na doença de Parkinson (YOUDIM; LAVIE, 1994). 


\section{OBJETIVOS}

\subsection{OBJETIVO GERAL}

Avaliar a função do NO na capacitação de espermatozoides equinos criopreservados.

\subsubsection{OBJETIVOS ESPECÍFICOS}

Analisar se a indução, inibição e remoção do NO do meio de capacitação influenciam nos padrões de motilidade e hiperativação de espermatozoides equinos criopreservados.

Analisar se a indução, inibição e remoção do NO do meio de capacitação influenciam na integridade de membrana plasmática e acrossomal de espermatozoides equinos criopreservados.

Avaliar se a indução, inibição e remoção do NO do meio de capacitação espermática influenciam na quantidade de NO em espermatozoides equinos criopreservados.

Avaliar se a indução, inibição e remoção do NO do meio de capacitação espermática influenciam na fosforilação do aminoácido tirosina na membrana plasmática dos espermatozoides equinos criopreservados.

Verificar se a indução, inibição e remoção do NO do meio de capacitação espermática influenciam na peroxidação lipídica da membrana plasmática de espermatozoides equinos criopreservados. 


\section{HIPÓTESES}

A L-arginina é precursora do $\mathrm{NO}$ em espermatozoides equinos.

$\mathrm{O} \mathrm{N}^{\mathrm{G}}$-nitro-L-arginina-metil-ester (L-NAME) é um inibidor de $\mathrm{NO}$ em espermatozoides equinos.

O azul de metileno é um removedor do NO.

I A incubação de espermatozoides equinos pós-descongelação com L-arginina no meio de capacitação leva a um aumento da produção de NO e consequentemente a um aumento das características de motilidade espermática e da hiperativação dos espermatozoides.

A incubação de espermatozoides equinos pós-descongelação com L-arginina no meio de capacitação induz a capacitação espermática, avaliada pela taxa de reação acrossômica, fosforilação do aminoácido tirosina e pela peroxidação lipídica da membrana plasmática.

A inibição ou remoção do NO através da incubação de espermatozoides equinos pós-descongelação com L-NAME ou azul de metileno, respectivamente, no meio de capacitação, leva a redução da capacitação espermática avaliada pelas características de motilidade, de hiperativação, taxa de reação acrossômica, fosforilação dos resíduos do aminoácido tirosina e pela peroxidação lipídica da membrana plasmática. 


\section{MODELO HIPOTÉTICO GRÁFICO}

Figura 1 - Modelo hipotético gráfico

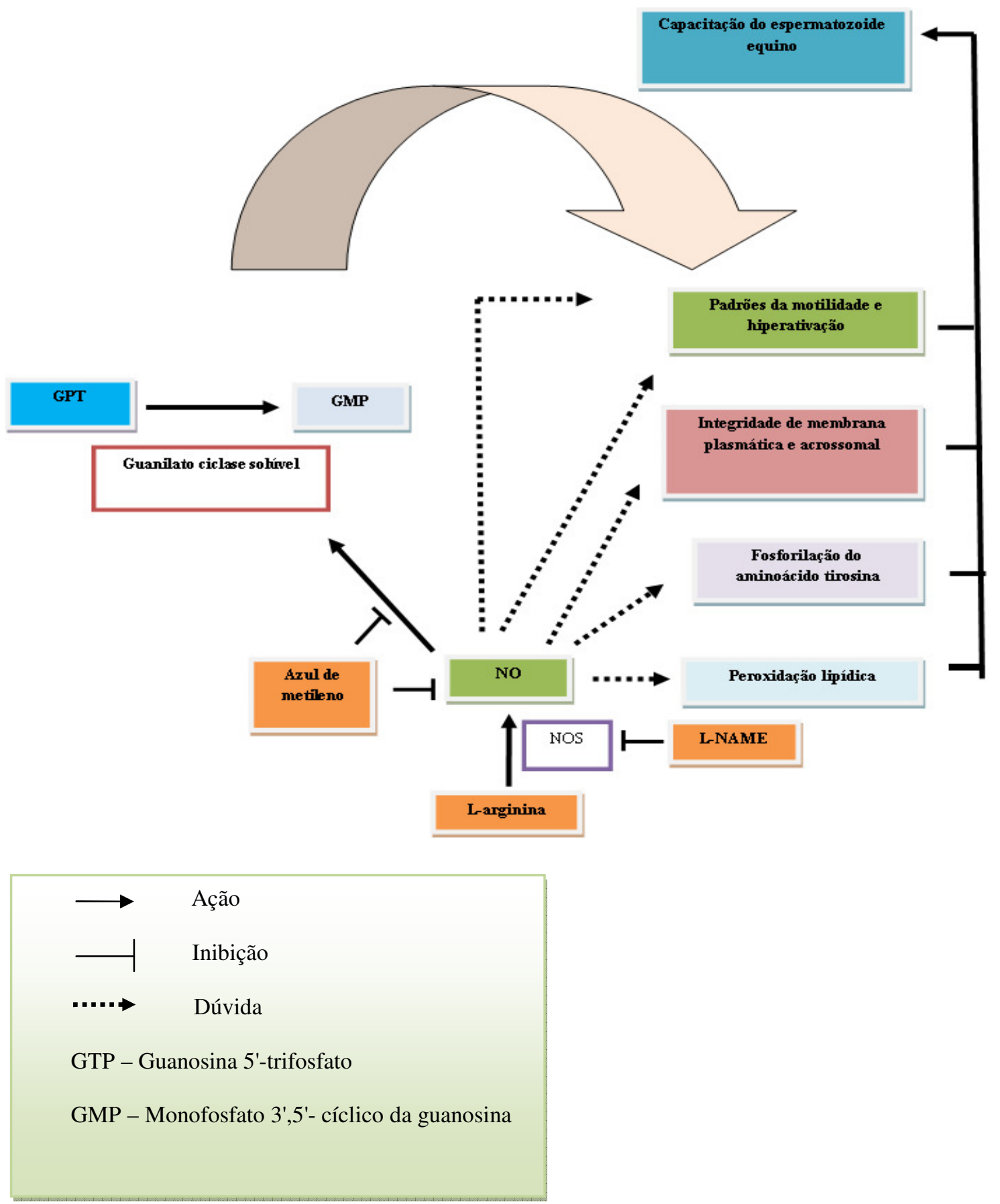

Fonte: (FRANCO-SILVA, 2013)

Legenda: 1 - A L-arginina estímula a produção de NO. 2) O L-name inibe a NOS. 3) O azul de metileno remove o NO do meio e inibe a produção da guanilato ciclase solúvel impedindo que o GTP se converta em GMP. 


\section{MATERIAL E MÉTODOS}

\subsection{LOCAL}

O experimento foi realizado no Laboratório de Biotecnologia do Sêmen e Andrologia do Centro de Biotecnologia em Reprodução Animal do Departamento de Reprodução Animal da Faculdade de Medicina Veterinária e Zootecnia da Universidade de São Paulo, localizado no campus Administrativo de Pirassununga.

\subsection{ANIMAIS}

Foram utilizados três garanhões dos quais foram obtidos três ejaculados de cada garanhão para a realização do experimento. Os animais foram submetidos a manejo nutricional e sanitários idênticos e ficaram alojados na dependência do setor de equideocultura do campus us Administrativo de Pirassununga (PCAPS-USP).

\subsection{COLHEITA DO SÊMEN E AVALIAÇÃO ESPERMÁTICA}

As colheitas de sêmen para os experimentos foram realizadas com vagina artificial, modelo Botucatu (Botupharma; Botucatu, São Paulo; Brasil), sendo a fração gelatinosa devidamente separada e descartada. Somente ejaculados com motilidade total acima de $65 \%$ foram submetidos à criopreservação com a finalidade de descartar animais que possam apresentar problemas de fertilidade.

\subsection{CONGELAÇÃO DO SÊMEN}


Realizada a análise da motilidade subjetiva do sêmen (in natura) este foi diluído 1:1 (sêmen:diluidor) em meio à base de leite desnatado (Botupharma; Botucatu, São Paulo; Brasil) para posterior centrifugação a $500 \mathrm{~g}$. Após a centrifugação, os sedimentos obtidos foram suspendidos com diluidor para congelação (Botu-Crio ${ }^{\circledR}$ - Botupharma; Botucatu, São Paulo; Brasil), a fim de se obter uma concentração final de $200 \times 10^{6}$ espermatozoides/mL. O sêmen diluído foi envasado em palhetas de 0,5 mL (IMV Internacional, St. Paul, Minesota, USA) e então submetidos à congelação. A criopreservação do sêmen foi realizada utilizando um sistema automático (TK $3000^{\circledR}$, TK Tecnologia em Congelação Ltda., Uberaba, Minas Gerais, Brasil), composto por aparelho programável, equipado com um porta-palhetas, um compartimento de refrigeração e uma caixa térmica para nitrogênio líquido. Para a refrigeração, as palhetas foram colocadas no porta-palhetas, o qual foi acondicionado ao compartimento de refrigeração, permanecendo neste até alcançar $5^{\circ} \mathrm{C}$, obedecendo a uma curva de refrigeração de $-0,25{ }^{\circ} \mathrm{C} /$ minuto, com duração aproximada de 1 hora e 15 minutos. Ao atingir $5{ }^{\circ} \mathrm{C}$, o porta-palhetas foi removido para a caixa térmica contendo nitrogênio líquido na qual a curva de congelação foi realizada com uma taxa de $-20{ }^{\circ} \mathrm{C} /$ minuto de $5{ }^{\circ} \mathrm{C}$ até $-120{ }^{\circ} \mathrm{C}$. Após a curva de congelação as palhetas foram removidas do portapalhetas e imersas em nitrogênio liquido $\left(-196{ }^{\circ} \mathrm{C}\right)$. Por fim, as palhetas foram raqueadas e armazenadas em botijões criogênicos.

\subsection{MEIO DE INCUBAÇÃO ESPERMÁTICA}

O meio de incubação utilizado foi o meio de fertilização in vitro (FIV) para bovinos, testado por Gardes et al. (2011), para a capacitação de espermatozoides equinos, o qual é constituído de $114 \mathrm{mM}$ de $\mathrm{NaCl}, 3,22 \mathrm{mM}$ de $\mathrm{KCl}, 0,5 \mathrm{mM}$ de $\mathrm{MgCl}_{2} \cdot 6 \mathrm{H}_{2} \mathrm{O}, 0,34 \mathrm{mM}$ de $\mathrm{NaH}_{2} \mathrm{PO}_{4}, 25 \mathrm{mM}$ de $\mathrm{NaHCO}_{3}, 2 \mathrm{mM}$ de $\mathrm{CaCl}_{2} \cdot 2 \mathrm{H}_{2} \mathrm{O}$, lactato de sódio a 50\%, $6 \mathrm{mg} / \mathrm{mL}$ de BSA, $50 \mu \mathrm{g} / \mathrm{mL}$ de Gentamicina, $2 \mathrm{mM}$ de Penicilamina, $1 \mathrm{mM}$ de hipotaurina, $250 \mu \mathrm{M}$ de epinefrina (Anexo A). 
Foram descongeladas quatro palhetas da mesma partida e do mesmo garanhão em banho-maria a $37^{\circ} \mathrm{C}$ por 30 segundos. Em seguida, o sêmen foi centrifugado a $500 \mathrm{~g}$ e após a retirada do sobrenadante, foi resuspendido no meio nos seguintes tratamentos: Controle (C- meio FIV); L-NAME (L- $1 \mathrm{mM}$ de L-NAME em meio FIV) de acordo com Herrero et al. (2000); Azul de metileno (M-100 mM de Azul de metileno em meio FIV) de acordo com Lewis et al. (1996) e Donnelly et al. (1997); L-arginina (A- 10 mM de L-arginina em meio FIV) de acordo com O’Flaherty, Rodriguez, Srivastava (2004 ); L-arginina + L-NAME (AL-10 mM de L-arginina+1 mM de L-NAME em meio FIV) e L-arginina + Azul de metileno (AM-10 mM de L-arginina $+100 \mathrm{mM}$ de azul de metileno). Todas as amostras foram suspendidas nos respectivos tratamentos até a obtenção de amostras com $25 \times 10^{6}$ espermatozoides/mL e então incubadas em estufa a $38{ }^{\circ} \mathrm{C}$ e $5 \%$ de $\mathrm{CO}_{2}$.

\subsection{DELINEAMENTO EXPERIMENTAL}

$\mathrm{O}$ experimento foi realizado em duas etapas distintas. Na primeira etapa, o sêmen foi descongelado, submetido aos tratamentos e analisado quanto às características da motilidade (CASA) nos tempos 0, 60, 120 e 300 minutos de incubação à $38{ }^{\circ} \mathrm{C}$ e $5 \%$ de $\mathrm{CO}_{2}$. $\mathrm{Na}$ segunda etapa, o sêmen também foi descongelado e submetido aos mesmos tratamentos da primeira etapa, entretanto, a análise foi realizada através da citometria de fluxo, onde foram avaliados aspectos quanto à integridade da membrana plasmática, porcentagem de células apresentando reação acrossômica, presença da fosforilação do aminoácido tirosina, produção de óxido nítrico e peroxidação das membranas espermáticas nos tempos 60, 120 e 300 minutos de incubação à $38^{\circ} \mathrm{C}$ e $5 \%$ de $\mathrm{CO}_{2}$.

Figura 2- Esquema simplificado do delineamento experimental 


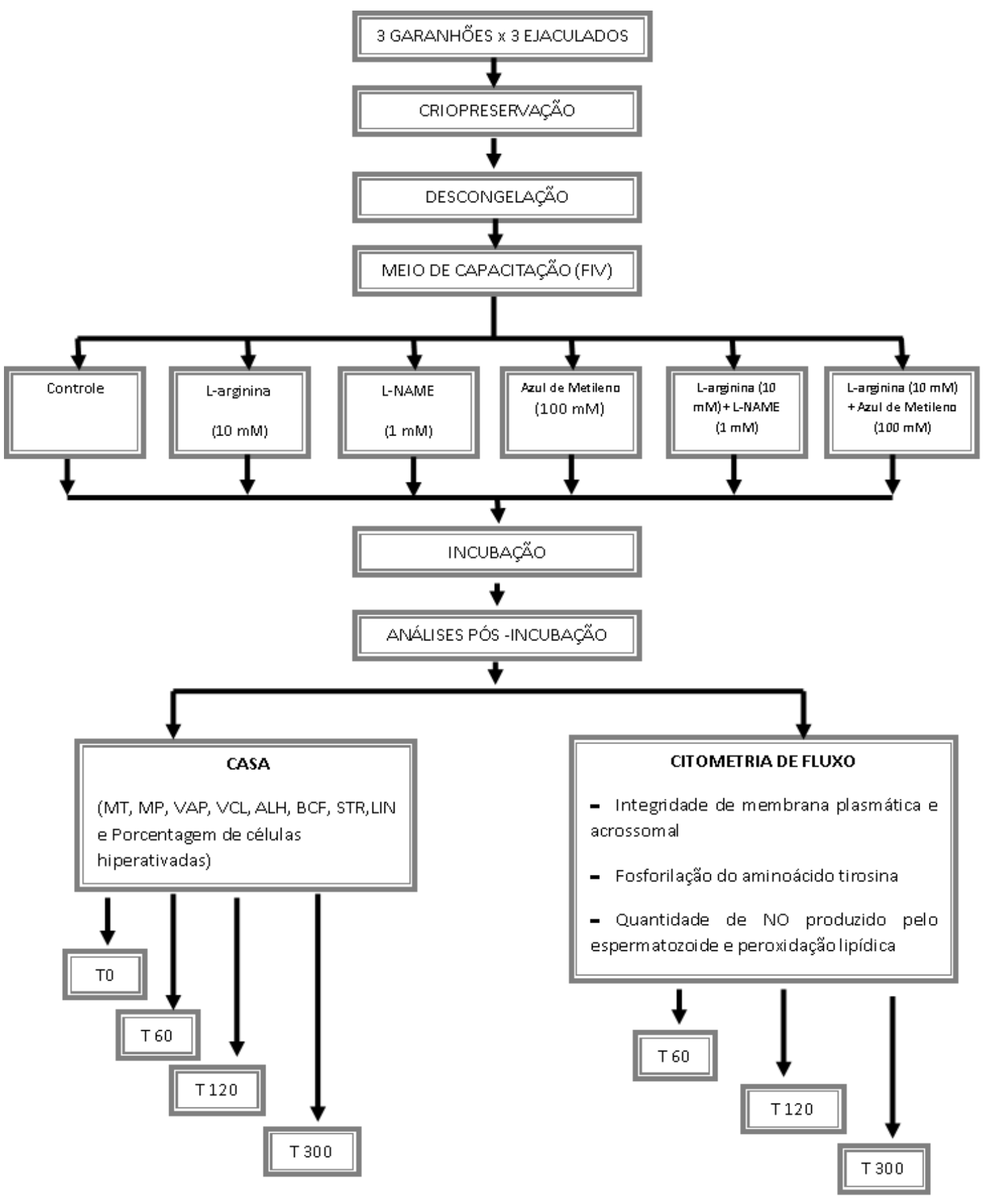

Fonte: (FRANCO-SILVA, 2013)

6.7.1 Primeira etapa: Avaliações computadorizadas das características da motilidade e detecção da população hiperativada 
As amostras foram examinadas pelo sistema de análise computadorizada da motilidade espermática (CASA) (Anexo B). As características analisadas foram: motilidade total (MT, \%), motilidade progressiva (MP, \%), velocidade de trajeto (VAP, $\mu \mathrm{m} / \mathrm{s}$ ), velocidade progressiva (VSL, $\mu \mathrm{m} / \mathrm{s}$ ), velocidade curvilinear (VCL, $\mu \mathrm{m} / \mathrm{s}$ ), amplitude do deslocamento lateral da cabeça (ALH, $\mu \mathrm{m})$, frequência de batimento (BCF, Hz), retilinearidade (STR, \%) e linearidade (LIN, \%); cujas definições foram descritas por Arruda (2000). Conjuntamente a estas análises foi realizado o ajuste da ferramenta Edit/Sort, usado para avaliar a porcentagem de células hiperativadas na amostra. O espermatozoide equino foi considerado como hiperativado quando este apresentou VCL $\geq 180 \mu \mathrm{m} / \mathrm{s}$ e um $\mathrm{ALH} \geq 12 \mu \mathrm{m}$, como descrito por Rathi et al. (2001).

\subsubsection{Segunda etapa: Análise por citometria de fluxo}

6.7.2.1 Avaliação da integridade da membrana plasmática e da reação acrossomal

As alíquotas retiradas das amostras, nos respectivos tratamentos, foram diluídas em tubos de microcentrifugação $(1,5 \mathrm{~mL})$ pré-aquecidos a $37 \mathrm{C}$, a fim de se obter amostras com concentração $5 \times 10^{6}$ espermatozoides por $\mathrm{mL}$. A seguir, foram adicionado $2 \mu \mathrm{L}$ da sonda Hoechst 33342 (H33342; 5 mg/mL, H-1399, Invitrogen Inc., Eugene, Oregon, EUA) com posterior incubação por 10 minutos a $37{ }^{\circ} \mathrm{C}$. O uso desta sonda teve como objetivo, corar o DNA das células espermáticas para que não houvesse a contagem de forma equivocada de partículas com o mesmo tamanho e granulosidade do espermatozoide. Passado o período de incubação, foi adicionado a amostra $3 \mu \mathrm{L}$ de iodeto de propídio (PI-0,5 mg/mL, Sigma-Aldrich Co., Saint Louis, Missouri, EUA), conjuntamente com $10 \mu \mathrm{L}$ de aglutinina de Pisum sativum conjugada ao isotiocionato de fluoresceína (FITC-PSA-100 $\mu \mathrm{g} / \mathrm{mL}$, Sigma-Aldrich Co., Saint Louis, Missouri, EUA) estas sondas com os seguintes objetivos: corar as células com membrana plasmática lesada iodeto de propídio positivo (IP +) (CELEGHINI et al., 2007; ANDRADE et al., 2012 ) e com a membrana acrossomal reagida (FITC-PSA positivo). Após 10 minutos de incubação a $37{ }^{\circ} \mathrm{C}$, os espermatozoides foram diluídos novamente, com a adição de $150 \mu \mathrm{L}$ e transferidos para tubos graduados de $15 \mathrm{~mL}\left(37^{\circ} \mathrm{C}\right)$. Com isso, as amostras 
apresentavam uma concentração de $2,5 \times 10^{6}$ espermatozoides por mL no momento de serem analisadas pela técnica de citometria de fluxo. Todas as amostras tiveram 10.000 células analisadas. O gráfico 1 representa um exemplo de gráfico de pontos gerados pelo software BD FACSDiva 6.0 após a contagem da amostra. A coloração com FITCPSA diferenciou a população de células vivas iodeto de propídio negativo (PI -) em dois grupos distintos. 1) Espermatozoides que não foram corados com FITC-PSA, ou seja, com a membrana acrossomal intacta (IAIM); 2) espermatozoides positivos para FITCPSA, indicando células com o acrossoma em processo de exocitose ou que já estavam reagidos (RAIM).

Gráfico 1 - Gráficos de pontos e histogramas gerados pela análise de 10.000 células por citometria de fluxo. Amostra corada com a associação H33342, IP, FITC-PSA permitindo a classificação dos espermatozoides equinos em quatro categorias - Pirassununga - 2013

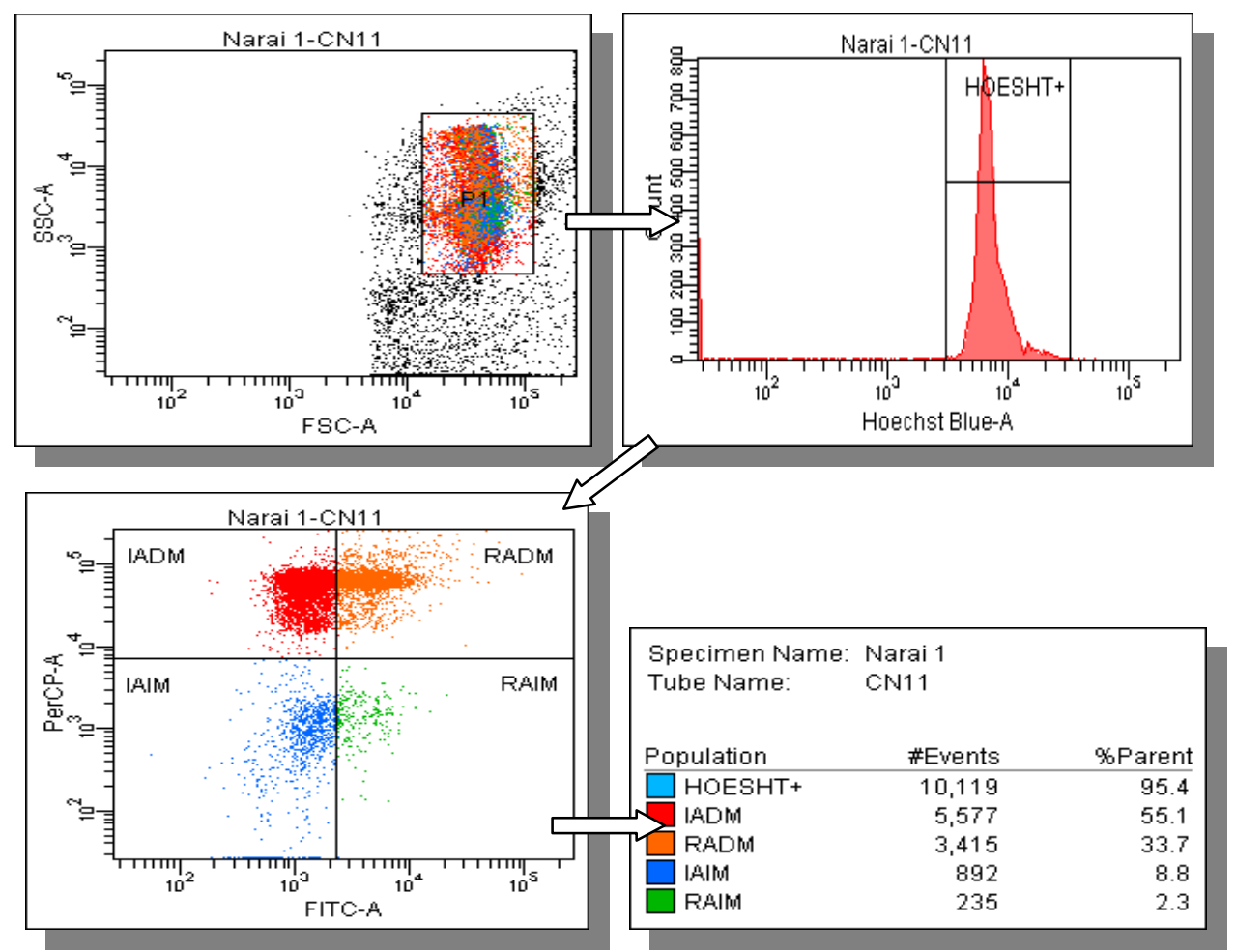

IADM - membrana plasmática lesada e membrana acrossomal não reagida. RADM - membrana plasmática lesada e membrana acrossomal reagida. IAIM - membrana plasmática íntegra e membrana acrossomal não reagida. RAIM - membrana plasmática íntegra e membrana acrossomal reagida. 
6.7.2.2 Detecção da fosforilação do aminoácido tirosina presente na superfície da membrana plasmática

As amostras de sêmen foram diluídas nos respectivos tratamentos a fim de se obter uma concentração final de 1 x $10^{6}$ espermatozoides $/ \mathrm{mL}$ em um volume final de $148 \mu \mathrm{L}$. Foram então adicionados $2 \mu \mathrm{L}$ de Hoechst 33342 com posterior incubação por 10 minutos a $37^{\circ} \mathrm{C}$. Em seguida, foi adicionado $0,75 \mu \mathrm{L}$ do anticorpo antifosfotirosina conjugado a uma fluoresceína (100 $\mu \mathrm{g} / \mathrm{mL}-\mathrm{CLONE}$ PY-20, F0426, Sigma-Aldrich Co., Saint Louis, Missouri, EUA) a esta suspensão, obtendo-se uma concentração final de 5 $\mu \mathrm{g} / \mathrm{mL}$ de anticorpo. Neste mesmo momento foi adicionado à amostra $3 \mu \mathrm{L}$ de iodeto de propídio a fim de marcar as células que apresentavam lesão na membrana plasmática. Em seguida, a amostra foi incubada por 5 minutos a $37 \mathrm{C}$ e então submetida à análise por citometria de fluxo (ANDRADE et al., 2012). O gráfico 2 apresenta um exemplo de gráfico de pontos e de um histograma gerados pelo software BD FACSDiva 6.0 após a contagem da amostra. As células íntegras (PI -) e marcadas com o anticorpo antifosfotirosina foram analisadas quanto à média da emissão de fluorescência captada no fotomultiplicador com long pass de 502 e band pass de $530 \pm 15$, esta faixa captada corresponde às células que estão marcadas pelo anticorpo.

Gráfico 2 - Gráficos de pontos gerados pela análise por citometria de fluxo em amostra corada com a associação de H33342, com anticorpo antifosfotirosina conjugado ao FITC e a sonda fluorescente IP. O valor obtido é indicado no quadro como a média em unidades arbitrárias (ua) - Pirassununga - 2013

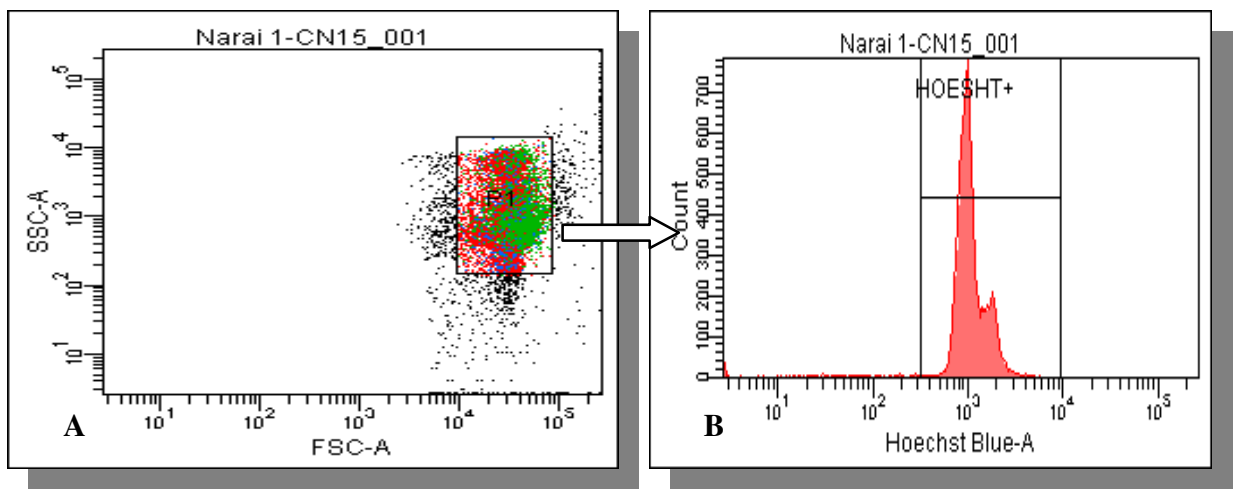




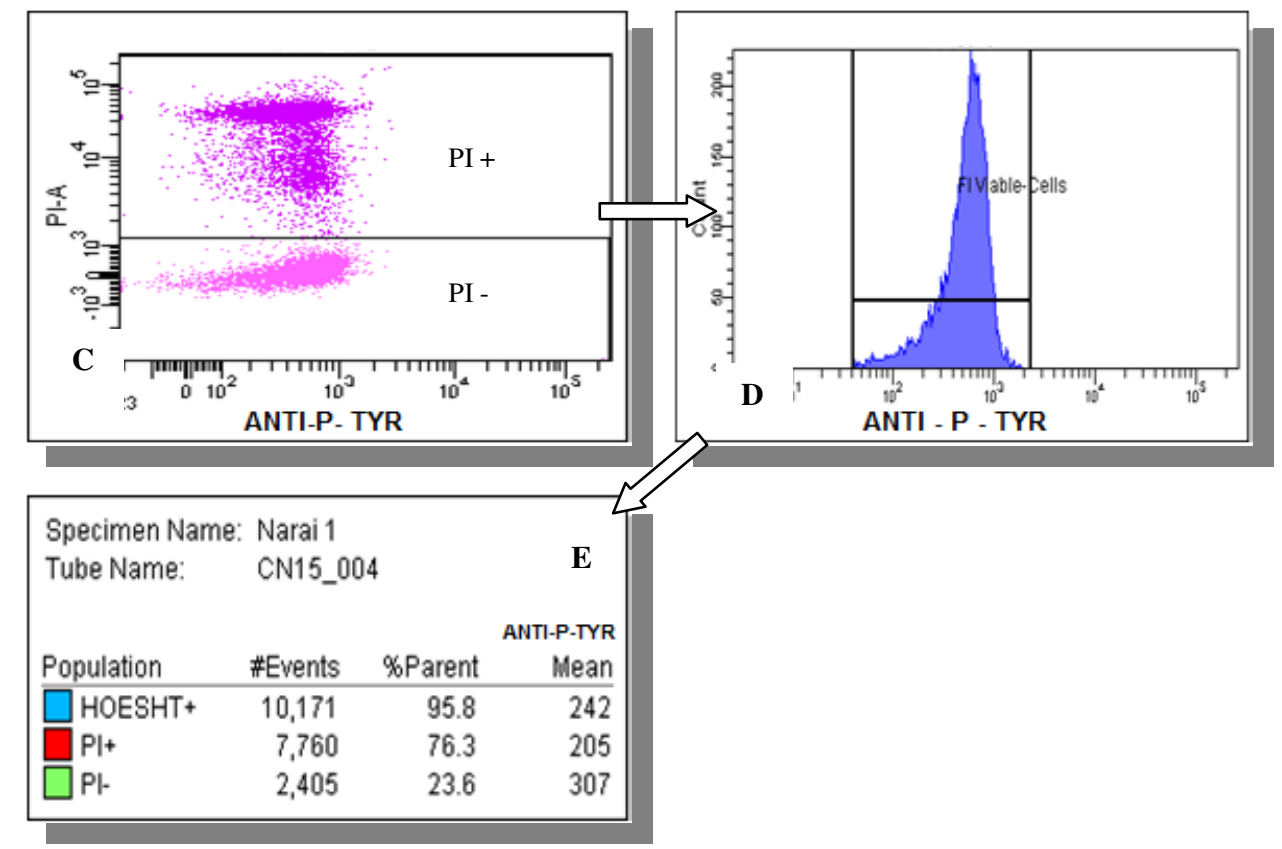

Fonte: (FRANCO-SILVA, 2013)

Legenda 2 - (A) Side scatter $\times$ forward scatter no gráfico de pontos (dot plot). (B) Histograma mostrando partículas contendo DNA (espermatozoides) marcadas com H33342. (C) No gráfico de pontos podem-se observar duas categorias distintas, sendo as PI - os espermatozóides equinos com a membrana plasmática íntegra e selecionados para a avaliação da detecção dos resíduos do aminoácido antifosfotirosina. (D) $\mathrm{O}$ histograma apresenta a população selecionada PI - que está sendo analisada quanto à distribuição da fluorescência captada no fotomultiplicador com long pass de 502 e band pass de $530 \pm 15 \mathrm{~nm}$. (E) Os valores médios da intensidade de fluorescência obtidos a partir do histograma

6.7.2.3 Dosagem por citometria de fluxo da quantidade de óxido nítrico produzido pelo espermatozoide equino

As amostras de sêmen foram diluídas nos respectivos tratamentos a fim de se obter uma concentração final de $1 \times 10^{6}$ espermatozoides $/ \mathrm{mL}$ em um volume final de $148 \mu \mathrm{L}$. Foram então adicionados $2 \mu \mathrm{L}$ de Hoechst 33342 e incubadas por 10 minutos a $37^{\circ} \mathrm{C}$. Em seguida, foi adicionado $0,5 \mu \mathrm{L}$ da sonda 4,5-diaminofluorescein-2/diacetate (DAF2/DA, $10 \mu \mathrm{M}$, Calbiochem, San Diego, California, EUA), com posterior incubação a $37{ }^{\circ} \mathrm{C}$ por 20 minutos (LAMPIAO; STRIJIDOM; PLESSIS, 2006). Neste mesmo momento foi adicionado à amostra $3 \mu \mathrm{L}$ de iodeto de propídio a fim de marcar as células que apresentavam lesão na membrana plasmática. Em seguida a amostra foi incubada por 5 minutos a $37{ }^{\circ} \mathrm{C}$ para então ser submetida à análise por citometria de fluxo. O gráfico 3 apresenta um exemplo de gráficos de pontos e de histogramas gerados pelo software BD FACSDiva 6.0 após a contagem da amostra. As células 
íntegras (PI -) e marcadas com a DAF-2/DA foram analisadas quanto à média da emissão de fluorescência captada no fotomultiplicador com long pass de 502 e band pass de $530 \pm 15$, esta faixa captada corresponde às células que estão marcadas pela sonda.

Gráfico 3 - Gráfico de pontos gerados pela análise por citometria de fluxo em amostra corada com a associação de H33342, mais 4,5-diaminofluorescein-2/diacetate (DAF) e iodeto de propídio (PI). O valor obtido é indicado no quadro como a média em unidades arbitrárias (ua) Pirassununga - 2013
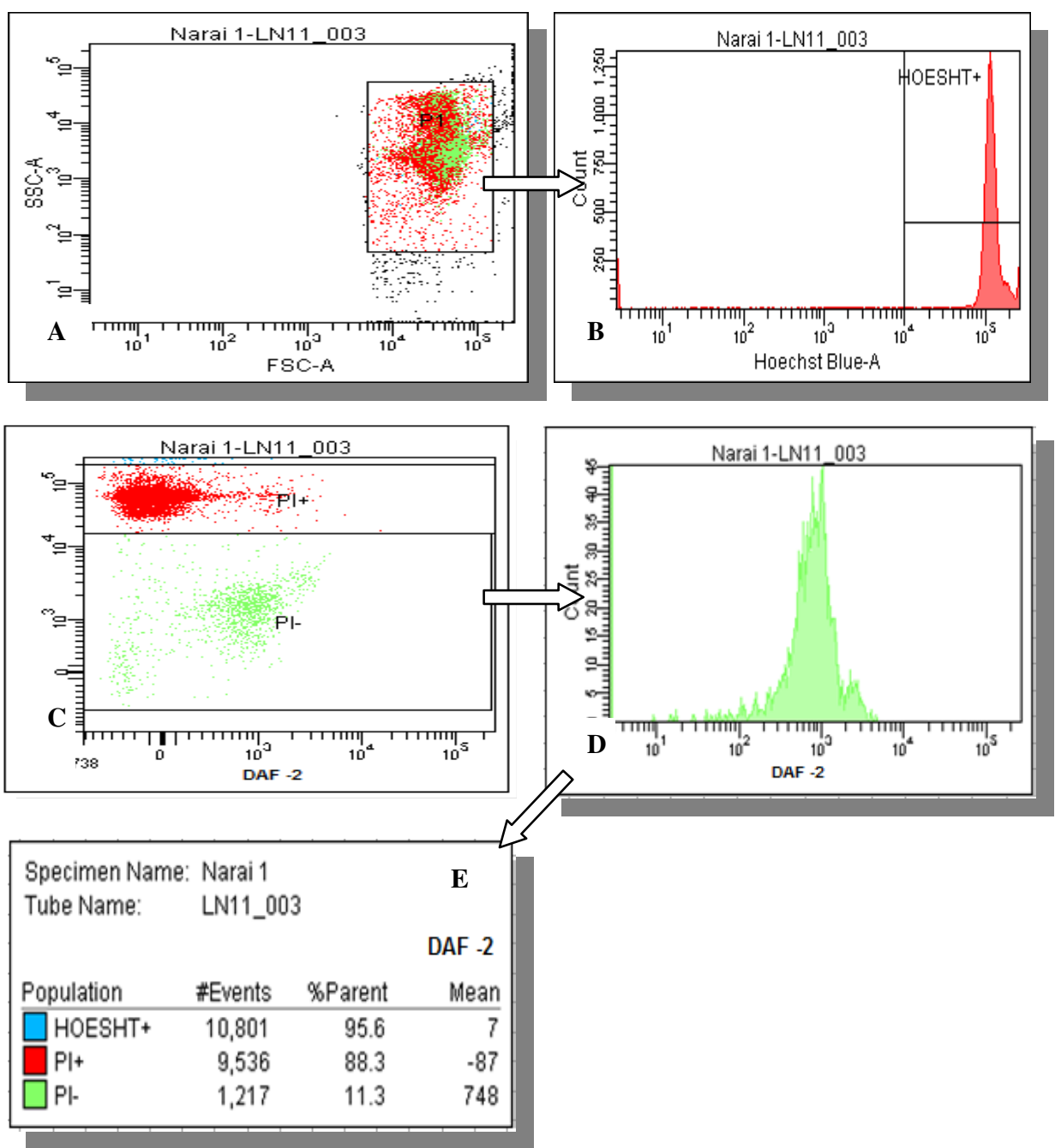

Fonte: (FRANCO-SILVA, 2013)

Legenda 3 - (A) Side scatter $\times$ forward scatter no gráfico de pontos (dot plot). (B) Histograma mostrando partículas contendo DNA (espermatozoides) marcadas com H33342. (C) No gráfico de pontos podem-se observar duas categorias distintas, sendo as PI - os espermatozóides equinos com a membrana plasmática íntegra e selecionados para a avaliação da detecção da quantidade de óxido nítrico produzido. (D) $O$ histograma apresenta a população selecionada PI - que está sendo analisada quanto à distribuição da fluorescência captada no fotomultiplicador com long pass de 502 e band pass de $530 \pm 15 \mathrm{~nm}$. (E) Os valores médios da intensidade de fluorescência obtidos a partir do histograma 
As amostras foram retiradas e diluídas nos respectivos tratamentos para se obter no momento da adição da sonda uma concentração de $5 \times 10^{6}$ espermatozoides $/ \mathrm{mL}$ com um volume final de 499,5 $\mu \mathrm{L}$. Em seguida, as amostras foram coradas com 0,5 $\mu \mathrm{L}$ da sonda C11-BODIPY ${ }^{581 / 591}(1 \mathrm{mg} / \mathrm{mL}, \mathrm{D}-3861$, Invitrogen Inc., Eugene, Oregon, EUA) por 30 minutos a $37^{\circ} \mathrm{C}$. Após este período de incubação, $145 \mu \mathrm{L}$ destas amostras foram transferidos para outro tubo de microcentrifuga e adicionados $2 \mu \mathrm{L}$ de Hoechst 33342 (5 mg/mL, H-1399, InvitrogenInc., Eugene, Oregon, EUA) sendo incubado novamente por 10 minutos a $37^{\circ} \mathrm{C}$. O uso desta sonda teve como objetivo, corar o DNA das células espermáticas para que não houvesse a contagem de forma equivocada de partículas com o mesmo tamanho e granulosidade do espermatozoide. Então, adicionou-se a amostra $3 \mu \mathrm{L}$ de iodeto de propídio $(0,5 \mathrm{mg} / \mathrm{mL}$, L0770, Sigma-Aldrich Co., Saint Louis, Missouri, EUA) a fim de servir como um marcador das células com membrana plasmática lesada (ANDRADE et al., 2012). Após 5 minutos de incubação a $37{ }^{\circ} \mathrm{C}$, os espermatozoides foram diluídos com a adição de $150 \mu \mathrm{L}$ de meio FIV e transferidos para tubos graduados de $15 \mathrm{~mL}\left(37^{\circ} \mathrm{C}\right)$. Com isso, as amostras apresentavam uma concentração de $2,5 \times 10^{6}$ espermatozoides por mL no momento de serem analisadas por citometria de fluxo. Foram analisadas 10.000 células por amostra. O gráfico 4 apresenta um exemplo de gráficos de pontos e de histogramas gerados pelo software BD FACSDiva 6.0 após a contagem da amostra. As células viáveis (PI-) e coradas com a sonda C11-BODIPY ${ }^{581 / 591}$ foram analisadas quanto à média da emissão de fluorescência captada no fotomultiplicador com long pass de 502 e band pass de $530 \pm 15 \mathrm{~nm}$, esta faixa captada corresponde às células que estão sofrendo ação da peroxidação.

Gráfico 4 - Gráfico de pontos gerados pela análise por citometria de fluxo em amostra corada com a associação de H33342, C C $_{11}$ BODIPY $^{581 / 591}$ e a sonda fluorescente IP. O valor obtido é indicado no quadro como a média em unidades arbitrárias (ua) - Pirassununga - 2013

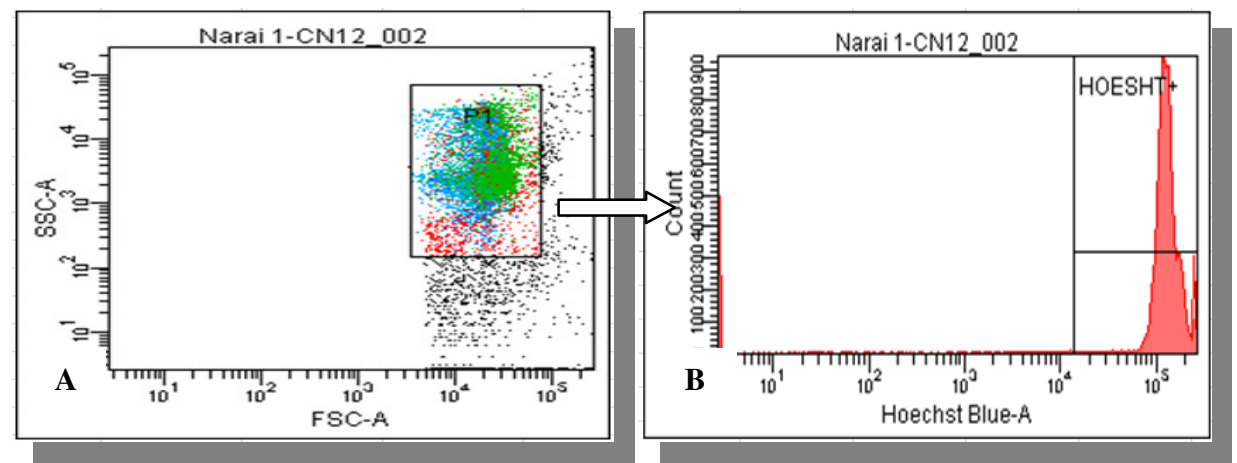




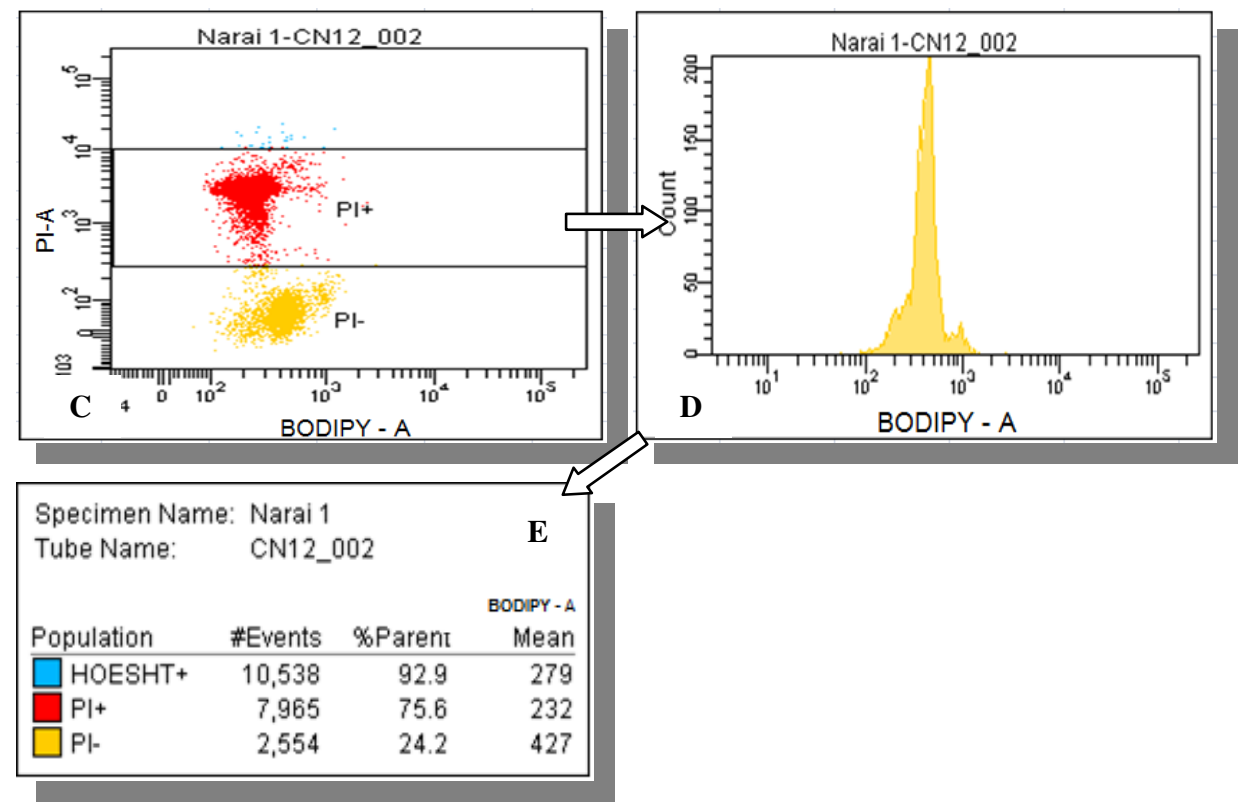

Fonte: (FRANCO-SILVA, 2013)

Legenda 4 - (A) Side scatter $\times$ forward scatter no gráfico de pontos (dot plot). (B) Histograma mostrando partículas contendo DNA (espermatozoides) marcadas com H33342. (C) No gráfico de pontos podem-se observar duas categorias distintas, sendo as PI - os espermatozóides equinos com a membrana plasmática íntegra e selecionados para a avaliação da peroxidação lipídica das membranas. (D) O histograma apresenta a população selecionada PI - que está sendo analisada quanto à distribuição da fluorescência captada no fotomultiplicador com long pass de 502 e band pass de $530 \pm 15 \mathrm{~nm}$. (E) Os valores médios da intensidade de fluorescência obtidos a partir do histograma

\subsection{Análise Estatística}

Os dados obtidos dos procedimentos experimentais foram analisados com prévia verificação da normalidade dos resíduos e da homogeneidade das variâncias. As variáveis dependentes que não atenderam às premissas estatísticas foram submetidas à transformação em arco-seno. Os dados transformados ou não foram submetidos à análise de variância (PROC GLM), empregando-se o programa SAS (1998). Às análises estatísticas destas variáveis foram ainda adicionadas do fator medidas repetidas no tempo, referentes aos diferentes momentos de amostragem. As probabilidades de interações com o tempo foram determinadas pelo teste de Greenhouse-Geisse, utilizando-se o comando REPEATED gerado pelo procedimento GLM (PROC GLM do SAS). As análises dentro de cada tempo foram realizadas pelo teste de Tukey. As hipóteses testadas foram consideradas significativas quando $\mathrm{p}<0,05$. 


\section{RESULTADOS}

\subsection{PARTE 1 - AVALIAÇÃO COMPUTADORIZADA DAS CARACTERÍSTICAS DA MOTILIDADE E DETECÇÃO DA POPULAÇÃO HIPERATIVADA}

O NO pode aumentar ou diminuir a motilidade espermática dependendo da concentração utilizada (O'FLAHERTY; RODRIGUEZ; SRIVASTAVA, 2004). Por este motivo, nós estudamos o efeito da indução da geração de NO (L-arginina), inibição (L-NAME) e da sua remoção pelo azul de metileno, nas características da motilidade e hiperativação de espermatozoides equinos criopreservados.

Os grupos que receberam azul de metileno (M e AM) apresentaram valores iguais ou próximos a zero para todos os padrões de motilidade (MT, MP,VAP, VSL, VCL, ALH, BCF, STR, LIN, RAP) e para porcentagem de células hiperativadas em todos os tempos de incubação. Verificamos que em todos os tempos e tratamentos o LNAME não inibiu a motilidade total (MT). A MT apenas diferiu entre os tratamentos no tempo 0 (tempo*tratamento, $\mathrm{p}<0,05$ - Figura 3). Neste período os grupos que receberam L-arginina (A e AL) apresentaram uma redução nesta característica.

Figura 3 - Médias e desvios padrão da motilidade total (MT, \%) em função dos tempos de incubação (0, 60, 120 e $300 \mathrm{~min}$ ) e dos tratamentos (C, L, M, A, AL e AM) - Pirassununga - 2013

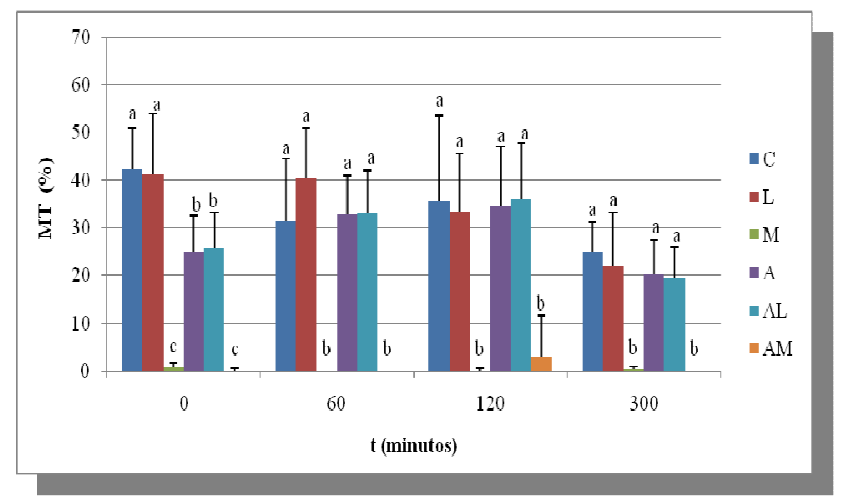

Legenda 5 - Controle (C- meio FIV), L-NAME (L-1 mM de L-NAME em meio FIV), Azul de metileno (M-100 mM de Azul de metileno em meio FIV), L-arginina (A-10 mM de L-arginina em meio FIV), Larginina + L-NAME (AL-10 mM de L-arginina+1 mM de L-NAME em meio FIV) e L-arginina + Azul de metileno (AM-10 mM de L-arginina + 100 mM de Azul de metileno)

Fonte: (FRANCO-SILVA, 2013) 
A motilidade progressiva (MP) foi outra característica que apresentou efeito dos tratamentos apenas no tempo 0 minutos (tempo*tratamento, $p<0,05$ - Figura 4). A MP foi menor para os grupos tratados com L-arginina (A e AL), acompanhando o ocorrido com a MT. Nesta variável o L-NAME também não inibiu a MP e os grupos tratados com azul de metileno reduziram total ou parcialmente esta variável em todos os tempos de incubação.

Figura 4 - Médias e desvios padrão da motilidade progressiva (MP, \%) em função dos tempos de incubação $(0,60,120$ e 300 min) e dos tratamentos (C, L, M, A, AL e AM) - Pirassununga 2013

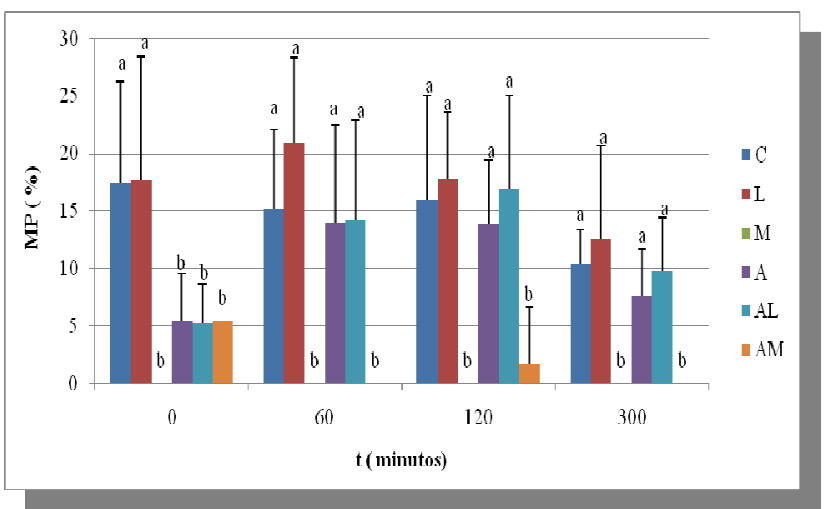

Legenda 6- Controle (C- meio FIV), L-NAME (L-1 mM de L-NAME em meio FIV), Azul de metileno (M-100 mM de Azul de metileno em meio FIV), L-arginina (A-10 mM de L-arginina em meio FIV), Larginina + L-NAME (AL-10 mM de L-arginina+1 mM de L-NAME em meio FIV) e L-arginina + Azul de metileno (AM-10 mM de L-arginina $+100 \mathrm{mM}$ de Azul de metileno)

Fonte: (FRANCO-SILVA, 2013)

Para a variável VAP não houve interação entre os tratamentos $(C, L, M, A, A L$ e AM) e os tempos de amostragem ( $p>0,05$; Figura 5). Deste modo, estudou-se somente o efeito dos tratamentos (Figura 6). A VAP foi reduzida $(\mathrm{p}<0,05)$ pela adição de Larginina. O tratamento L-NAME não produziu efeito sobre a VAP, uma vez que não diferiu do controle. A adição de L-NAME em AL não foi efetiva para inibir o efeito da L-argina sobre a VAP $(\mathrm{A}=\mathrm{AL}<\mathrm{C}=\mathrm{L} ; \mathrm{p}<0,05)$. A adição de azul de metileno reduziu a VAP em todos os tempos e tratamentos (M e AM).

Figura 5 - Médias e desvios padrões da velocidade de trajeto (VAP, $\mu \mathrm{m} / \mathrm{s}$ ) em função dos tempos de incubação (0, 60, 120 e 300 min) e dos tratamentos (C, L, M, A, AL e AM) - Pirassununga 2013 


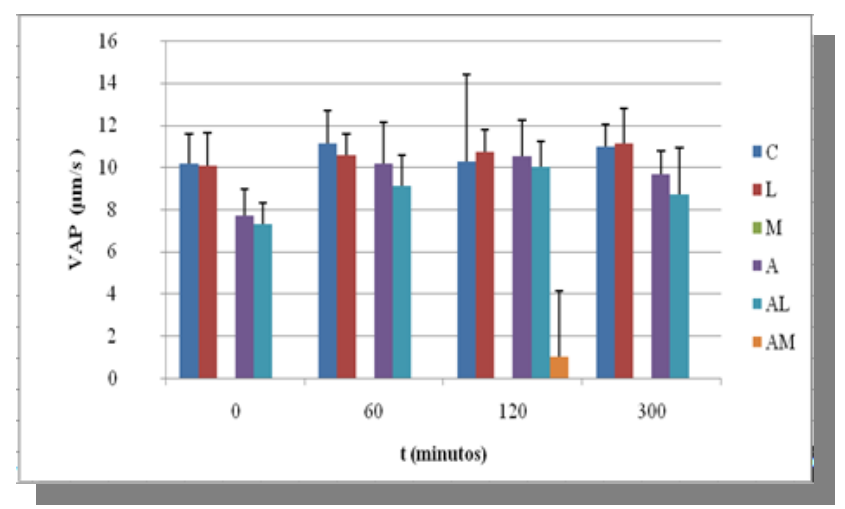

Legenda 7 - Controle (C- meio FIV), L-NAME (L-1 mM de L-NAME em meio FIV), Azul de metileno (M-100 mM de Azul de metileno em meio FIV), L-arginina (A-10 mM de L-arginina em meio FIV), Larginina + L-NAME (AL-10 mM de L-arginina+1 mM de L-NAME em meio FIV) e L-arginina + Azul de metileno (AM-10 mM de L-arginina $+100 \mathrm{mM}$ de Azul de metileno)

Fonte: (FRANCO-SILVA, 2013)

Figura 6 - Médias \pm desvios padrão do efeito dos tratamentos (C, L, M, A, AL e AM) na velocidade de trajeto (VAP, $\mu \mathrm{m} / \mathrm{s}$ ) - Pirassununga - 2013

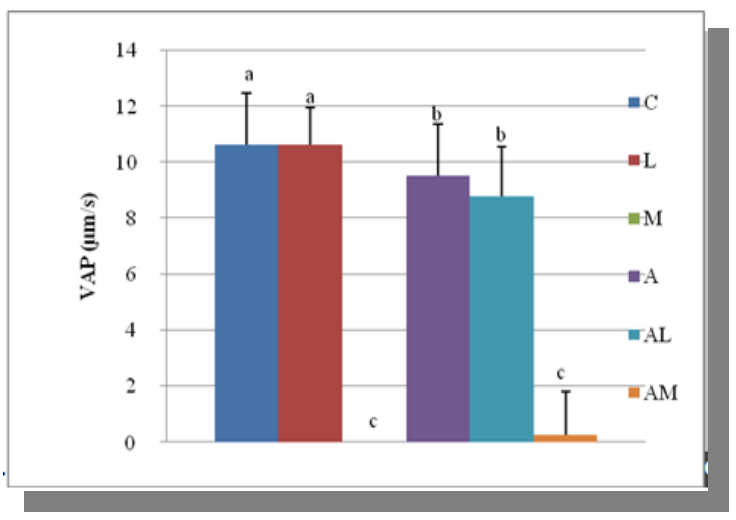

Legenda 8 - Controle (C- meio FIV), L-NAME (L-1 mM de L-NAME em meio FIV), Azul de metileno (M-100 mM de Azul de metileno em meio FIV), L-arginina (A-10 mM de L-arginina em meio FIV), Larginina + L-NAME (AL-10 mM de L-arginina+1 mM de L-NAME em meio FIV) e L-arginina + Azul de metileno (AM-10 mM de L-arginina $+100 \mathrm{mM}$ de Azul de metileno)

Fonte: (FRANCO-SILVA, 2013)

A VSL foi afetada pelos tratamentos em tempos distintos (tempo*tratamento, p<0,05-Figura 7). No tempo 0 as células que receberam L-arginina (A e AL) apresentaram os valores de VSL reduzidos $(\mathrm{p}<0,05)$ em relação aos grupos C e L. A adição de L-NAME não foi capaz de eliminar o efeito gerado pela adição de L-arginina $\mathrm{A}=\mathrm{AL}$. Nos tempos 60 e 120 minutos a VSL não apresentou diferença entre os tratamentos, com exceção dos tratamentos com azul de metileno. Já no tratamento 300 minutos observou-se uma redução $(\mathrm{p}<0,05)$ desta característica para o gupo Larginina+L-NAME, uma vez que este tratamento diferiu do controle $(\mathrm{p}<0,05)$. Os tratamentos com azul de metileno (M e AM) reduziram esta característica. Esta variável 
apresenta uma tendência de aumentar ao longo do tempo indicando que as células provalvelmente permanecenm íntegras.

Figura 7 - Médias \pm desvios padrão da velocidade progressiva (VSL, $\mu \mathrm{m} / \mathrm{s}$ ) em função dos tempos de incubação $(0,60,120$ e $300 \mathrm{~min})$ e dos tratamentos (C, L, M, A, AL, AM) - Pirassununga 2013

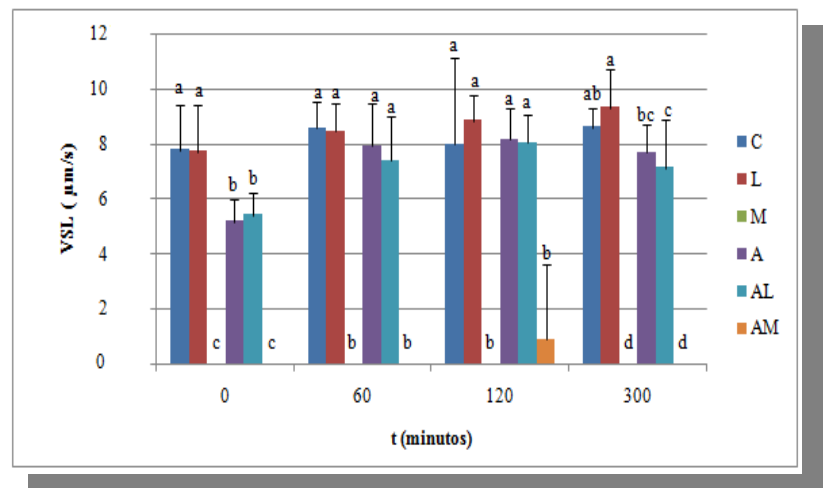

Legenda 9 - Controle (C- meio FIV), L-NAME (L-1 mM de L-NAME em meio FIV), Azul de metileno (M-100 mM de Azul de metileno em meio FIV), L-arginina (A-10 mM de L-arginina em meio FIV), Larginina + L-NAME (AL-10 mM de L-arginina+1 mM de L-NAME em meio FIV) e L-arginina + Azul de metileno (AM-10 mM de L-arginina $+100 \mathrm{mM}$ de Azul de metileno)

Fonte: (FRANCO-SILVA, 2013)

Para a variável VCL não houve interação entre tratamentos e tempos de incubação (tempo*tratamento, p>0,05-Figura 8). Porém, foi verificado que a associação L-arginina+L-NAME diminui os valores desta característica em comparação ao controle $(\mathrm{p}<0,05$; Figura 9) e que o azul de metileno reduziu esta variavel.

Figura 8 - Médias \pm desvios padrão da velocidade curvilinear (VCL, $\mu \mathrm{m} / \mathrm{s}$ ) em função dos tempos de incubação $(0,60,120$ e $300 \mathrm{~min})$ e dos tratamentos (C, L, M, A, AL, AM) - Pirassununga 2013

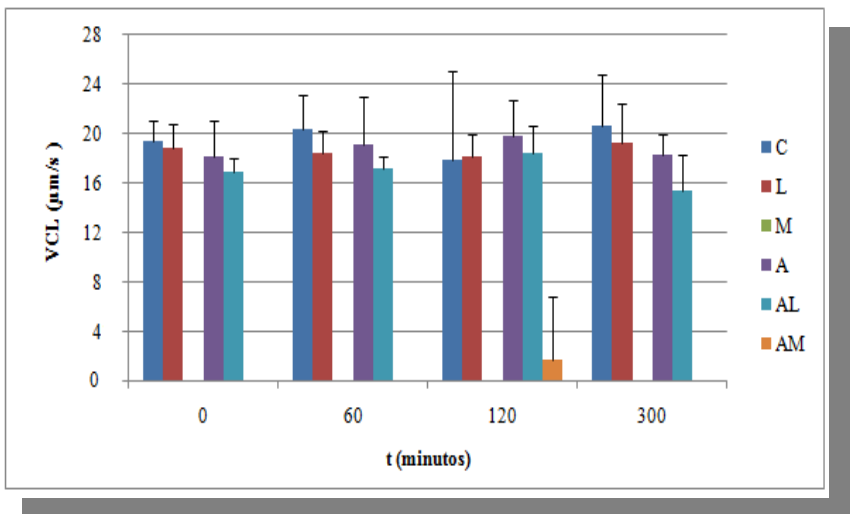

Legenda 10 - Controle (C- meio FIV), L-NAME (L-1 mM de L-NAME em meio FIV), Azul de metileno (M-100 mM de Azul de metileno em meio FIV), L-arginina (A-10 mM de L-arginina em meio FIV), Larginina + L-NAME (AL-10 mM de L-arginina+1 mM de L-NAME em meio FIV) e L-arginina + Azul de metileno (AM-10 mM de L-arginina $+100 \mathrm{mM}$ de Azul de metileno) 
Fonte: (FRANCO-SILVA, 2013)

Figura 9 - Médias \pm desvios padrão do efeito dos tratamentos (C, L, M, A, AL e AM) na velocidade curvilinear (VCL, $\mu \mathrm{m} / \mathrm{s}$ ) - Pirassununga - 2013

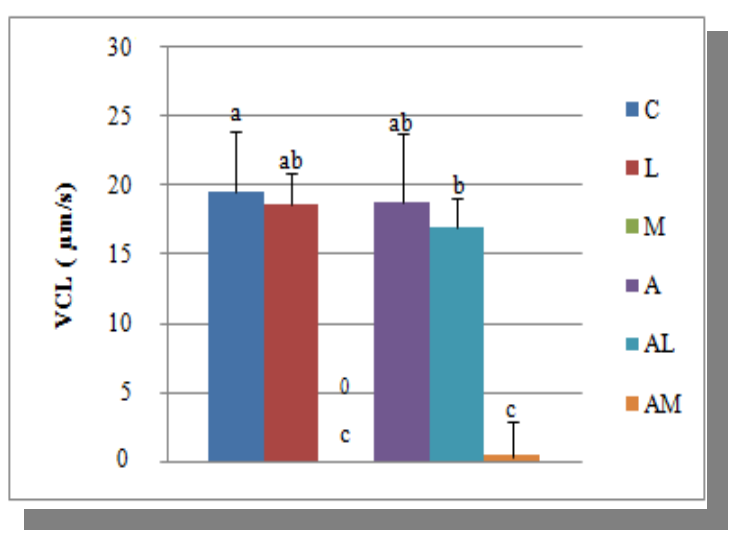

Legenda 11 - Controle (C- meio FIV), L-NAME (L-1 mM de L-NAME em meio FIV), Azul de metileno (M-100 mM de Azul de metileno em meio FIV), L-arginina (A-10 mM de L-arginina em meio FIV), Larginina + L-NAME (AL-10 mM de L-arginina+1 mM de L-NAME em meio FIV) e L-arginina + Azul de metileno (AM-10 mM de L-arginina + $100 \mathrm{mM}$ de Azul de metileno)

Fonte: (FRANCO-SILVA, 2013)

Quanto a ALH não houve interação entre os tempos de amostragem e os tratamentos ( $p>0,05$; figura 10). Ao estudar o efeito dos tratamentos verificamos uma redução desta característica apenas nos grupos que receberam azul de metileno (M e AM; Figura 11).

Figura 10 - Médias \pm desvios padrão da amplitude do deslocamento lateral da cabeça (ALH, $\mu \mathrm{m} / \mathrm{s}$ ) em função dos tempos de incubação (0, 60, 120 e $300 \mathrm{~min})$ e dos tratamentos (C, L, M, A, AL, AM) - Pirassununga - 2013

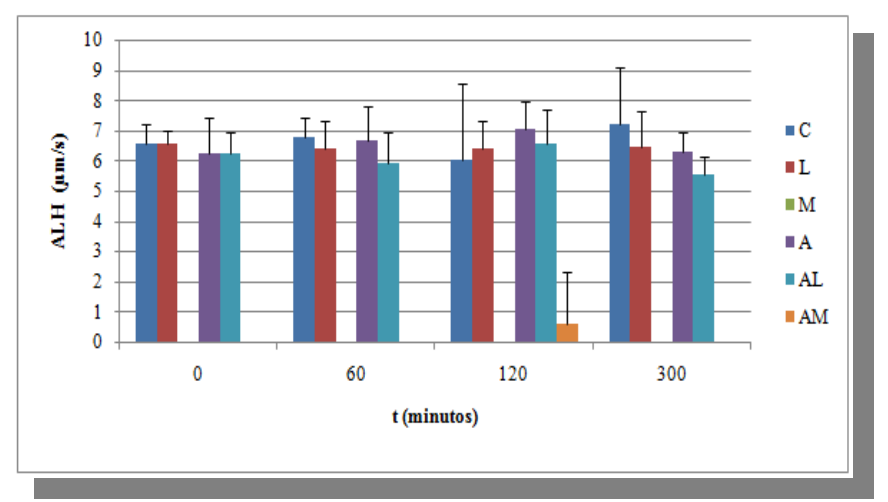

Legenda 12 - Controle (C- meio FIV), L-NAME (L-1 mM de L-NAME em meio FIV), Azul de metileno (M-100 mM de Azul de metileno em meio FIV), L-arginina (A-10 mM de L-arginina em meio FIV), Larginina + L-NAME (AL-10 mM de L-arginina+1 mM de L-NAME em meio FIV) e L-arginina + Azul de metileno (AM-10 mM de L-arginina + $100 \mathrm{mM}$ de Azul de metileno) 
Figura 11 - Médias \pm desvios padrão do efeito dos tratamentos (C, L, M, A, AL e AM) na amplitude do deslocamento lateral da cabeça (ALH, $\mu \mathrm{m} / \mathrm{s}$ ) - Pirassununga - 2013

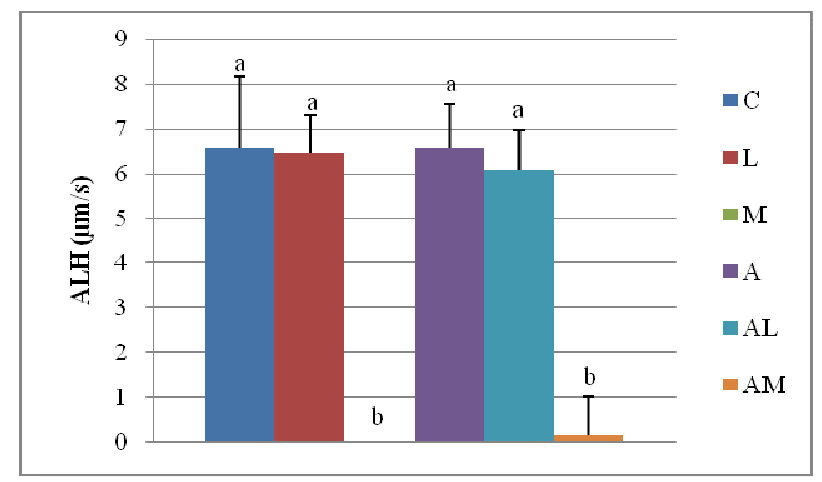

Legenda 13 - Controle (C- meio FIV), L-NAME (L-1 mM de L-NAME em meio FIV), Azul de metileno (M-100 mM de Azul de metileno em meio FIV), L-arginina (A-10 mM de L-arginina em meio FIV), Larginina + L-NAME (AL-10 mM de L-arginina+1 mM de L-NAME em meio FIV) e L-arginina + Azul de metileno (AM-10 mM de L-arginina $+100 \mathrm{mM}$ de Azul de metileno)

Fonte: (FRANCO-SILVA, 2013)

A variável $\mathrm{BCF}$ foi afetada pelos tratamentos apenas no tempo 120 minutos de incubação (tempo*tratamento p<0,05; Figura 12), onde observou-se que a associação Larginina+L-NAME apresentou maiores valores de BCF em relação ao tratamento controle $(\mathrm{p}<0,05)$. Porém, não houve diferença estatística entre o controle e os tratamentos L-NAME e L-arginina administrados isoladamente. Em todos os tempos verificou-se que o azul de metileno reduziu esta variável.

Figura 12 - Médias \pm desvios padrão do batimento flagelar $(\mathrm{BCF}, \mu \mathrm{m} / \mathrm{s})$ em função dos tempos de incubação (0, 60, 120 e 300 min) e dos tratamentos (C, L, M, A, AL, AM) - Pirassununga 2013

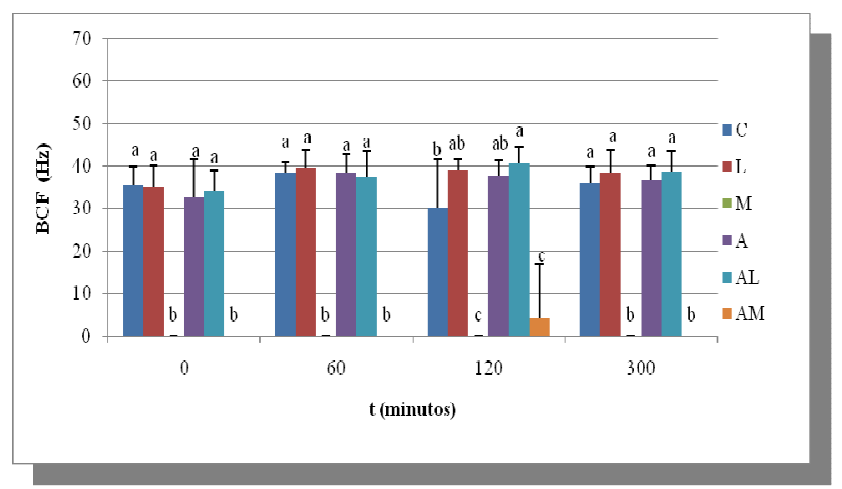

Legenda 14 - Controle (C- meio FIV), L-NAME (L-1 mM de L-NAME em meio FIV), Azul de metileno (M-100 mM de Azul de metileno em meio FIV), L-arginina (A-10 mM de L-arginina em meio FIV), Larginina + L-NAME (AL-10 mM de L-arginina+1 mM de L-NAME em meio FIV) e L-arginina + Azul de metileno (AM-10 mM de L-arginina + $100 \mathrm{mM}$ de Azul de metileno)

Fonte: (FRANCO-SILVA, 2013) 
Quanto a STR não foi verificada interação entre tempo de incubação e tratamento ( $p>0,05$-Figura 13). Na análise do efeito dos tratamentos não foi verificada diferenças significativas entre os tratamentos, exceto naqueles que causaram a imobilização dos espermatozoides (M e AM; Figura 14).

Figura 13 - Médias \pm desvios padrão da retilinearidade (STR, \%) em função dos tempos de incubação ( $(0$, 60, 120 e 300 min) e dos tratamentos (C, L, M, A, AL, AM) - Pirassununga - 2013

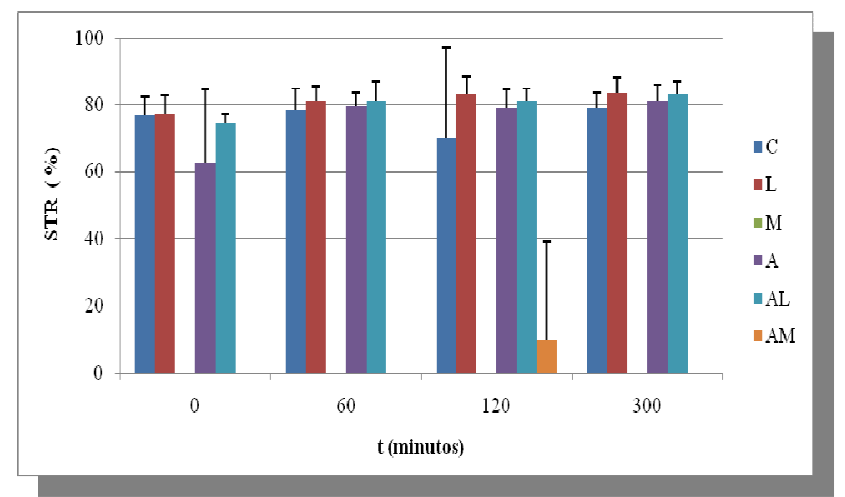

Legenda 15 - Controle (C- meio FIV), L-NAME (L-1 mM de L-NAME em meio FIV), Azul de metileno (M-100 mM de Azul de metileno em meio FIV), L-arginina (A-10 mM de L-arginina em meio FIV), Larginina + L-NAME (AL-10 mM de L-arginina+1 mM de L-NAME em meio FIV) e L-arginina + Azul de metileno (AM-10 mM de L-arginina + $100 \mathrm{mM}$ de Azul de metileno)

onte: (FRANCO-SILVA, 2013)

Figura 14 - Médias \pm desvios padrão do efeito dos tratamentos (C, L, M, A, AL e AM) na retiliniaridade (STR, \%) - Pirassununga - 2013

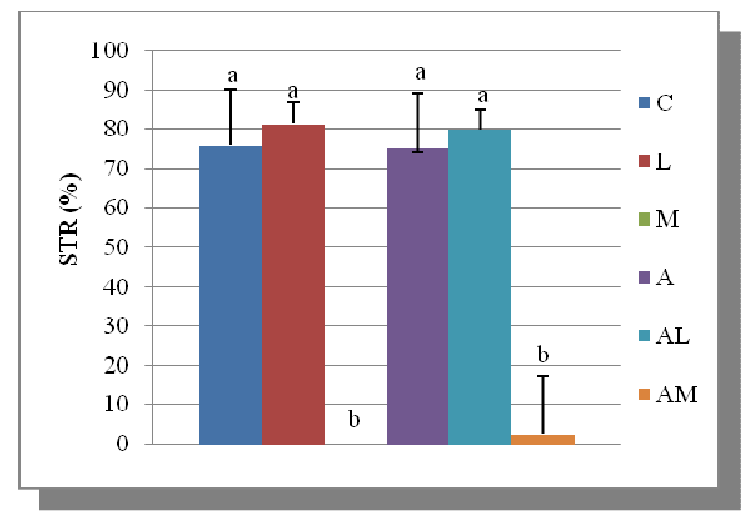

Legenda 16 - Controle (C- meio FIV), L-NAME (L-1 mM de L-NAME em meio FIV), Azul de metileno (M-100 mM de Azul de metileno em meio FIV), L-arginina (A-10 mM de L-arginina em meio FIV), Larginina + L-NAME (AL-10 mM de L-arginina+1 mM de L-NAME em meio FIV) e L-arginina + Azul de metileno (AM-10 mM de L-arginina + $100 \mathrm{mM}$ de Azul de metileno)

Fonte: (FRANCO-SILVA, 2013) 
Observamos que a variável LIN foi afetada pelos tratamentos apenas no tempo 0 minuto (tempo*tratamento, $\mathrm{p}<0,05$-Figura 15 ), onde identificamos uma redução desta característica para os grupos A e AL. Esta característica foi reduzida pelo do azul de metileno.

Figura 15 - Médias \pm desvios padrão em função dos tempos de incubação $(0,60,120$ e 300$)$ e tratamentos (C, L, M, A, AL e AM) na linearidade (LIN) - Pirassununga - 2013

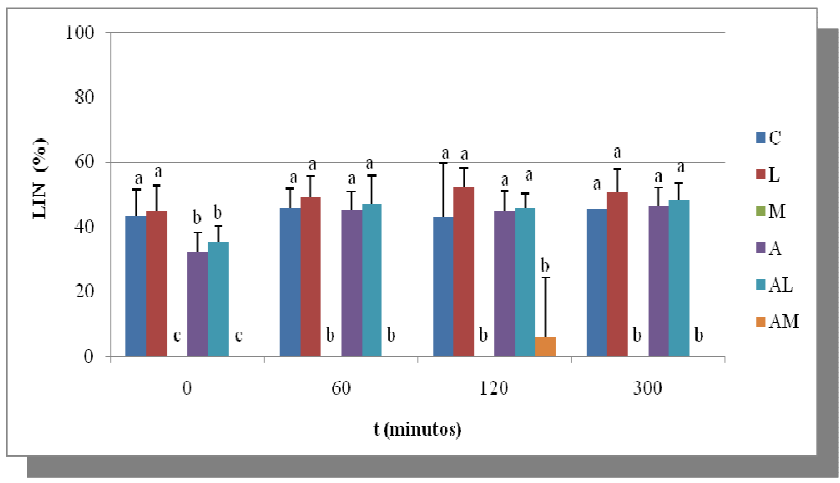

Legenda 17 - Controle (C- meio FIV), L-NAME (L-1 mM de L-NAME em meio FIV), Azul de metileno (M-100 mM de Azul de metileno em meio FIV), L-arginina (A-10 mM de L-arginina em meio FIV), Larginina + L-NAME (AL-10 mM de L-arginina+1 mM de L-NAME em meio FIV) e L-arginina + Azul de metileno (AM-10 mM de L-arginina + $100 \mathrm{mM}$ de Azul de metileno)

Fonte: (FRANCO-SILVA, 2013)

A RAP apresentou uma resposta semelhante às variáveis MT e MP, ou seja, apresentou diferenças nesta característica apenas no tempo 0 (tempo*tratamento, p<0,05; Figura 16). Neste tempo, os valores desta característica foram menores para os grupos que receberam a adição de L-arginina no meio de incubação (A e AL). O azul de metileno reduziu a porcentagem de células rápidas.

Figura 16 - Médias \pm desvios padrão em função dos tempos de incubação $(0,60,120$ e 300$)$ e tratamentos (C, L, M, A, AL e AM) nas porcentagem células rápidas (RAP) - Pirassununga - 2013

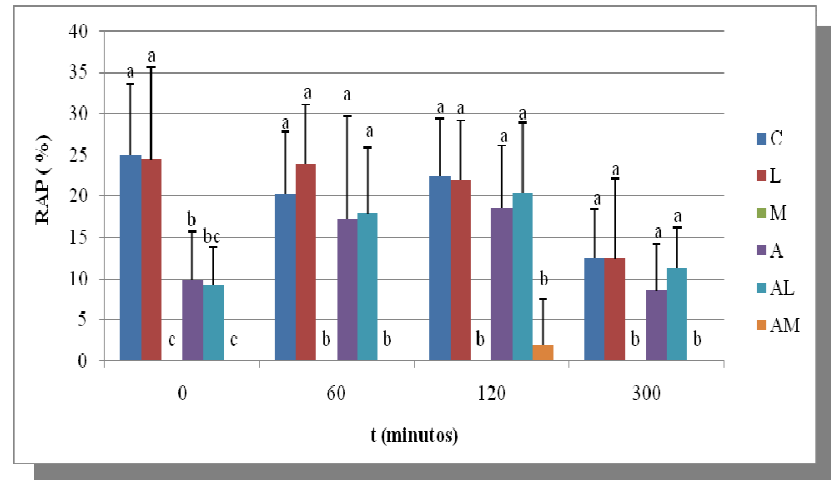


Legenda 18 - Controle (C- meio FIV), L-NAME (L-1 mM de L-NAME em meio FIV), Azul de metileno (M-100 mM de Azul de metileno em meio FIV), L-arginina (A-10 mM de L-arginina em meio FIV), Larginina + L-NAME (AL-10 mM de L-arginina+1 mM de L-NAME em meio FIV) e L-arginina + Azul de metileno (AM-10 mM de L-arginina + $100 \mathrm{mM}$ de Azul de metileno)

Fonte: (FRANCO-SILVA, 2013)

Para a característica porcetagem de células hiperativadas, não houve interação entre tratamento e tempo de incubação. (tempo*tratamento, p>0,05; Figura 17). Porém foi observado que a associação da L-arginina+L-NAME reduziu $(\mathrm{p}<0,05$; Figura 18) a porcentagem de células hiperativadas. $\mathrm{O}$ azul de metileno diminuiu a porcentagem de células hiperativadas.

Figura 17 - Médias \pm desvios padrão em função dos tempos de incubação $(0,60,120$ e 300$)$ e tratamentos (C, L, M, A, AL e AM) na porcntagem de células hiperativadas (HIPER) - Pirassununga 2013

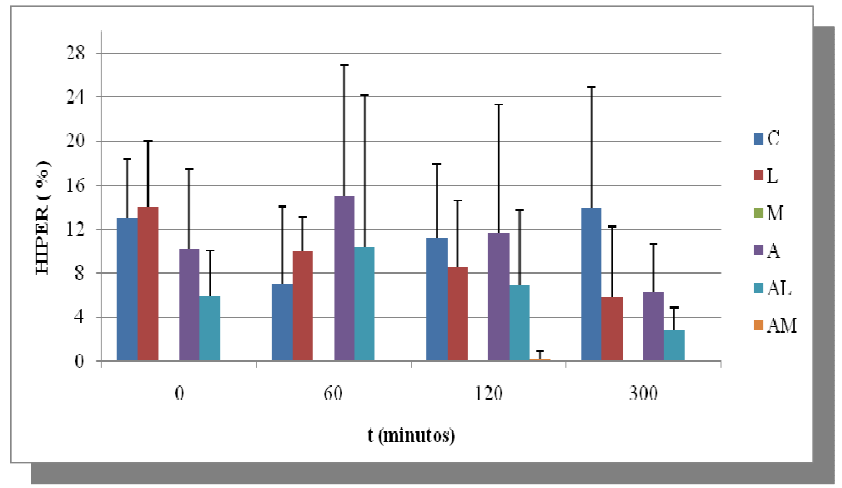

Legenda 19 - Controle (C- meio FIV), L-NAME (L-1 mM de L-NAME em meio FIV), Azul de metileno (M-100 mM de Azul de metileno em meio FIV), L-arginina (A-10 mM de L-arginina em meio FIV), Larginina + L-NAME (AL-10 mM de L-arginina+1 mM de L-NAME em meio FIV) e L-arginina + Azul de metileno (AM-10 mM de L-arginina + $100 \mathrm{mM}$ de Azul de metileno)

Fonte: (FRANCO-SILVA, 2013)

Figura 18 - Médias \pm desvios padrão do efeito dos tratamentos (C, L, M, A, AL e AM) na porcentagem de células hiperativadas (HIPER, \%) - Pirassununga - 2013

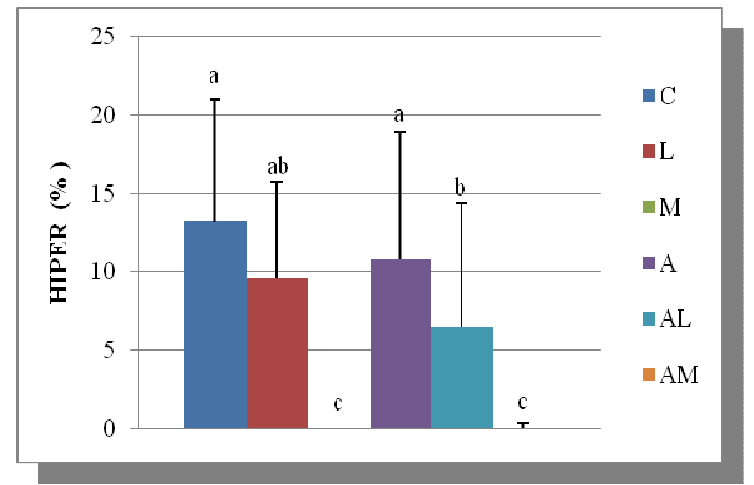

Legenda 20 - Controle (C- meio FIV), L-NAME (L-1 mM de L-NAME em meio FIV), Azul de metileno (M-100 mM de Azul de metileno em meio FIV), L-arginina (A-10 mM de L-arginina em meio FIV), L- 
arginina + L-NAME (AL-10 mM de L-arginina+1 mM de L-NAME em meio FIV) e L-arginina + Azul de metileno (AM-10 mM de L-arginina + $100 \mathrm{mM}$ de Azul de metileno)

Fonte: (FRANCO-SILVA, 2013)

\subsection{PARTE 2 - AVALIAÇÕES REALIZADAS POR CITOMETRIA DE FLUXO}

A variável porcentagem de células com membrana plasmática e acrossomal íntegras (IAIM) apresentou interação entre os tratamentos estipulados e os tempos de amostragem (tempo*tratamento, $\mathrm{p}<0,05$; Figura 19). Os espermatozoides incubados com a adição de azul de metileno (M e AM) apresentaram uma maior porcentagem de células com membrana plasmática e acrossomal íntegras aos 60 e 120 minutos de incubação. Porém, este efeito não se manteve até os 300 minutos indicando uma possível perda da integridade de membrada e provável indicativo de que as células possam estar entrando em estado de capacitação se levarmos em consideração, que durante este evento (capacitação) ocorre várias mudanças fisiológicas no espermatozoide, como as alterações na fluidez das membranas, o aumento da concentração de íons intracelulares, aumento das sinalizações intracelulares e mudanças bioquímicas, como alterações na composição lipídica, produção de espécies reativas de oxigênio (EROS), migração das proteínas de membrana, exteriorização de receptores, ativação dos canais iônicos, produção intracelular de AMP cíclico e a fosforilação do aminoácido tirosina (VISCONTI et al., 1998; VISCONTI; KOPF, 1998; VICONTI et al., 2005).

Figura 19 - Médias \pm desvios padrão da porcentagem de células com membrana plasmática e acrossomal íntegras (IAIM, \%) nos tratamentos (C, L, M, A, AL e AM) - Pirassununga - 2013

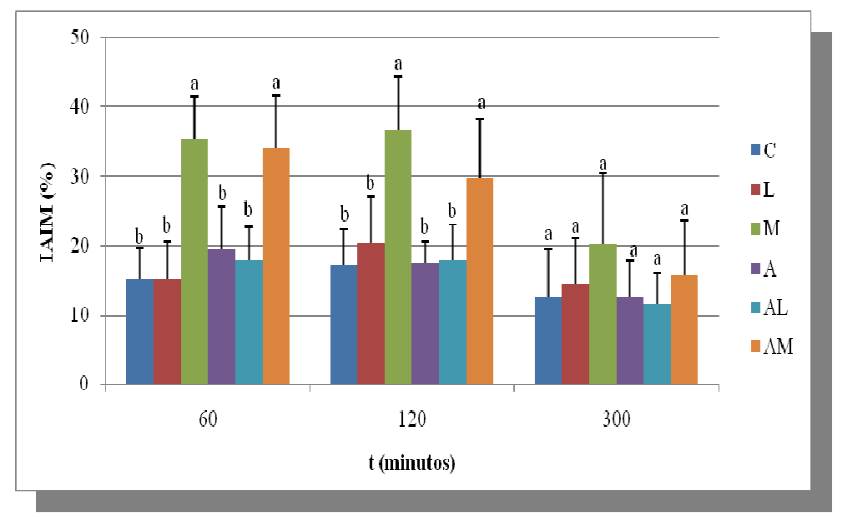

Legenda 21 - Controle (C- meio FIV), L-NAME (L-1 mM de L-NAME em meio FIV), Azul de metileno (M-100 mM de Azul de metileno em meio FIV), L-arginina (A-10 mM de L-arginina em meio FIV), L- 
arginina + L-NAME (AL-10 mM de L-arginina+1 mM de L-NAME em meio FIV) e L-arginina + Azul de metileno (AM-10 mM de L-arginina + $100 \mathrm{mM}$ de Azul de metileno)

Fonte: (FRANCO-SILVA, 2013)

A quantidade de células apresentando reação acrossomal (RAIM) não diferiu entre os tratamentos em função do tempo (tempo*tratamento, $p>0,05$; Figura 20). No entanto, verificamos um aumento de células com reação acrossomal nos grupos que receberam L-arginina (A e AL; Figura 21) diferindo estatisticamente dos tratamentos com a adição do azul de metileno (M e AM; p<0,05). Porém estes tratamentos (A e AL) não diferiram estatisticamente do controle. Os tratamentos controle e L-NAME apresentaram valores intermediários, não diferindo entre si, e não diferindo dos tratamentos com a adição de azul de metileno e daqueles com a adição de L-arginina.

Figura 20 - Médias \pm desvios padrão da porcentagem de células com membrana plasmática íntegra dos tratamentos (C, L, M, A, AL e AM) apresentando reação acrossomal (RAIM, \%) Pirassununga - 2013

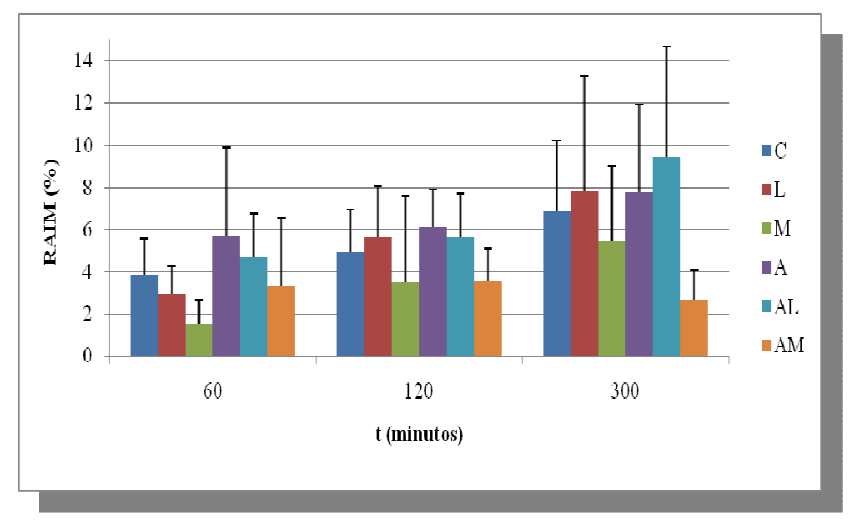

Legenda 22 - Controle (C- meio FIV), L-NAME (L-1 mM de L-NAME em meio FIV), Azul de metileno (M-100 mM de Azul de metileno em meio FIV), L-arginina (A-10 mM de L-arginina em meio FIV), Larginina + L-NAME (AL-10 mM de L-arginina+1 mM de L-NAME em meio FIV) e L-arginina + Azul de metileno (AM-10 mM de L-arginina + 100 mM de Azul de metileno)

Fonte: (FRANCO-SILVA, 2013)

Figura 21 - Médias \pm desvios padrão do efeito dos tratamentos (C, L, M, A, AL e AM) na porcentagem de células íntegras apresentando reação acrosômica (RAIM, \%) - Pirassununga - 2013 


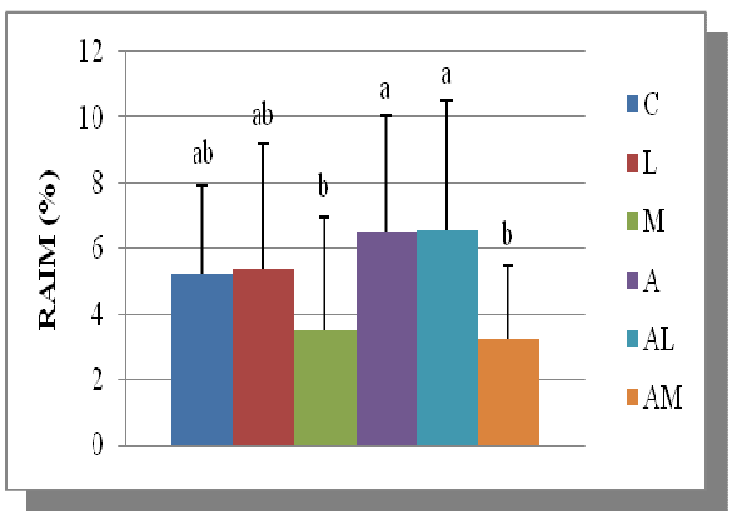

Legenda 23 - Controle (C- meio FIV), L-NAME (L-1 mM de L-NAME em meio FIV), Azul de metileno (M-100 mM de Azul de metileno em meio FIV), L-arginina (A-10 mM de L-arginina em meio FIV), Larginina + L-NAME (AL-10 mM de L-arginina+1 mM de L-NAME em meio FIV) e L-arginina + Azul de metileno (AM-10 mM de L-arginina + $100 \mathrm{mM}$ de Azul de metileno)

Fonte: (FRANCO-SILVA, 2013)

A produção de NO pelos espermatozoides não teve influência dos tratamentos em função do tempo (tempo*tratamento, p>0,05; Figura 22). Contudo, a adição de azul de metileno (M e AM) foi capaz de diminuir a produção de NO. A associação Larginina+L-NAME (AL) apresentou valor intermediário em relação aos tratamentos A e AM, porém não diferiu destes tratamentos (Figura 23).

Figura 22 - Médias \pm desvios padrão da produção de óxido nítrico pelos espermatozoides íntegros $(\mathrm{NO}+$, a.u) em função dos tempos de incubação (60, 120 e $300 \mathrm{~min})$ e dos tratamentos (C, L, M, A, AL e AM) - Pirassununga - 2013

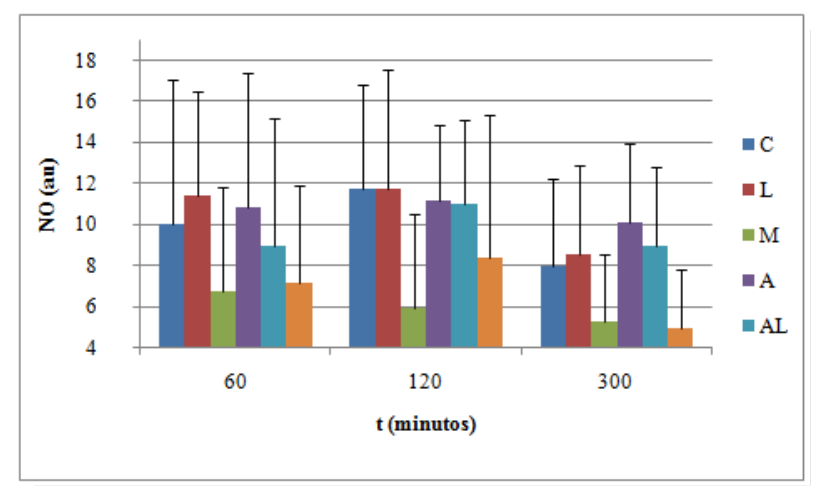

Legenda 24 - Controle (C- meio FIV), L-NAME (L-1 mM de L-NAME em meio FIV), Azul de metileno (M-100 mM de Azul de metileno em meio FIV), L-arginina (A-10 mM de L-arginina em meio FIV), Larginina + L-NAME (AL-10 mM de L-arginina+1 mM de L-NAME em meio FIV) e L-arginina + Azul de metileno (AM-10 mM de L-arginina + $100 \mathrm{mM}$ de Azul de metileno)

Fonte: (FRANCO-SILVA, 2013)

Figura 23 - Médias \pm desvios padrão do efeito dos tratamentos (C, L, M, A, AL e AM) na produção de óxido nítrico pelos espermatozoides íntegros (NO +; au.) - Pirassununga - 2013 


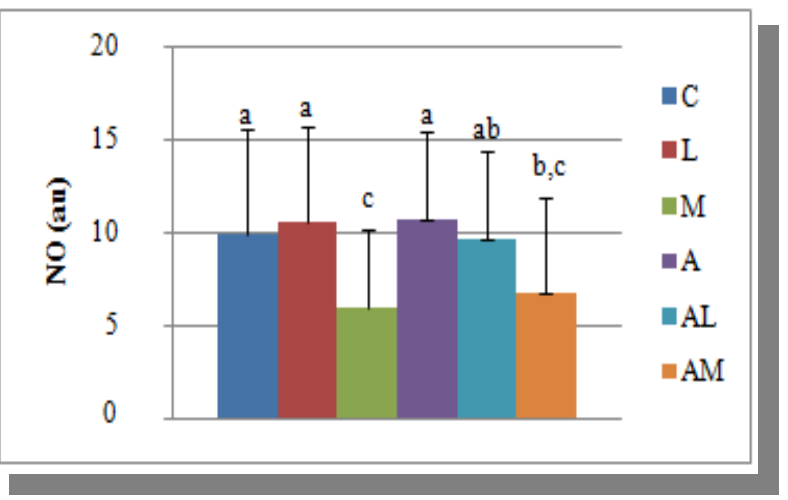

Legenda 25 - Controle (C- meio FIV), L-NAME (L-1 mM de L-NAME em meio FIV), Azul de metileno (M-100 mM de Azul de metileno em meio FIV), L-arginina (A-10 mM de L-arginina em meio FIV), Larginina + L-NAME (AL-10 mM de L-arginina+1 mM de L-NAME em meio FIV) e L-arginina + Azul de metileno (AM-10 mM de L-arginina + $100 \mathrm{mM}$ de Azul de metileno)

Fonte: (FRANCO-SILVA, 2013)

A fosforilação do aminoácido tirosina, independentemente do tratamento, não se alterou durante os tempos de incubação (tempo*tratamento, p>0,05-Figura 24), porém, podemos observar que independente desta variável ser significativa houve uma leve redução aos 120 e 300 min de incubação podendo ser um possível indicativo de capacitação espermática. Foi verificada uma redução da fosforilação nos espermatozoides incubados com o removedor de NO (M e MN, p<0,05; Figura 25).

Figura 24 - Médias \pm desvios padrão da fosforilação dos resíduos do aminoácido tirosina presente na superfície dos espermatozoides íntegros (ANT +, a.u.) em função dos tempos de incubação $(60,120$ e $300 \mathrm{~min})$ e dos tratamentos (C, L, M, A, AL e AM) - Pirassununga - 2013

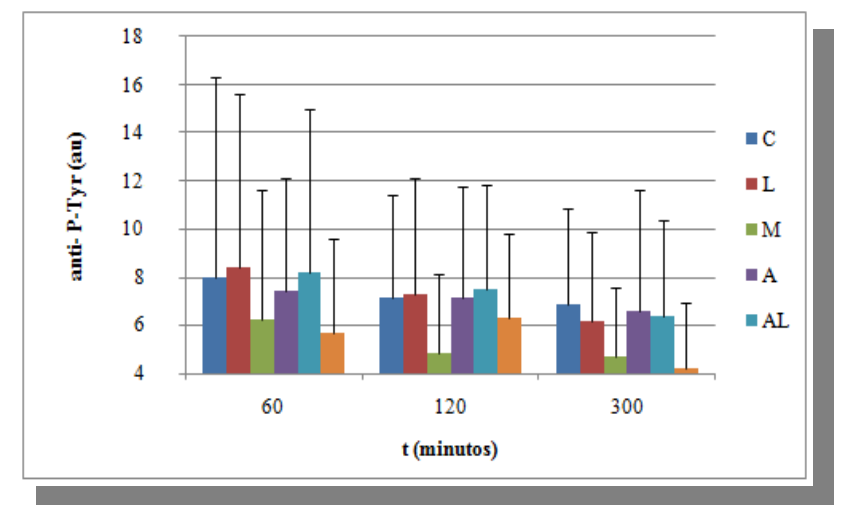

Legenda 26 - Controle (C- meio FIV), L-NAME (L-1 mM de L-NAME em meio FIV), Azul de metileno (M-100 mM de Azul de metileno em meio FIV), L-arginina (A-10 mM de L-arginina em meio FIV), Larginina + L-NAME (AL-10 mM de L-arginina+1 mM de L-NAME em meio FIV) e L-arginina + Azul de metileno (AM-10 mM de L-arginina + $100 \mathrm{mM}$ de Azul de metileno)

Fonte: (FRANCO-SILVA, 2013) 
Figura 25 - Médias \pm desvios padrão do efeito dos tratamentos (C, L, M, A, AL e AM) na fosforilação dos resíduos do aminoácido tirosina presente na superfície dos espermatozoides íntegros (ANT+, a.u.) Pirassununga - 2013

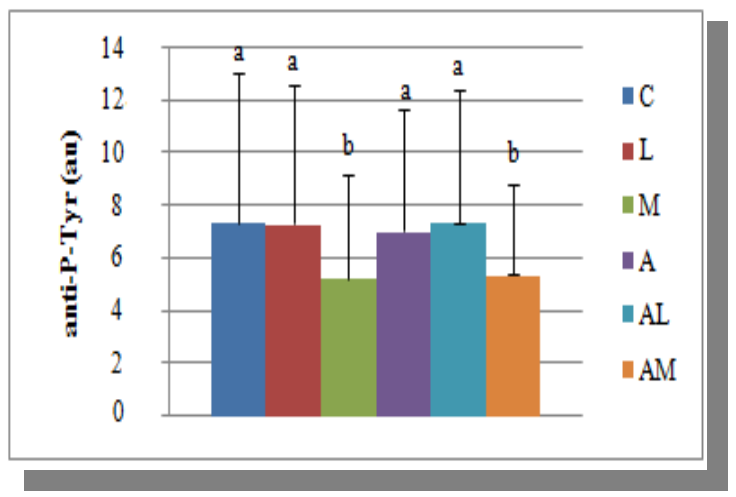

Legenda 27 - Controle (C- meio FIV), L-NAME (L-1 mM de L-NAME em meio FIV), Azul de metileno (M-100 mM de Azul de metileno em meio FIV), L-arginina (A-10 mM de L-arginina em meio FIV), Larginina + L-NAME (AL-10 mM de L-arginina+1 mM de L-NAME em meio FIV) e L-arginina + Azul de metileno (AM-10 mM de L-arginina + $100 \mathrm{mM}$ de Azul de metileno)

Fonte: (FRANCO-SILVA, 2013)

A peroxidação lipídica das membranas também não foi influenciada pelos tratamentos em função do tempo (tempo*tratamento, p>0,05; Figura 26). Desta forma, a peroxidação lipídica assim como as variáveis fosforilação do aminoácido tirosina e produção de NO foram reduzidas nos tratamentos que receberam azul de metileno (M e AM; Figura 27).

Figura 26 - Médias \pm desvios padrão da peroxidação lipídica das membranas espermáticas em células íntegras (BODI +, a.u.) em função dos tempos de incubação (60, 120 e 300 min) e dos tratamentos (C, L, M, A, AM e AM)- Pirassununga - 2013

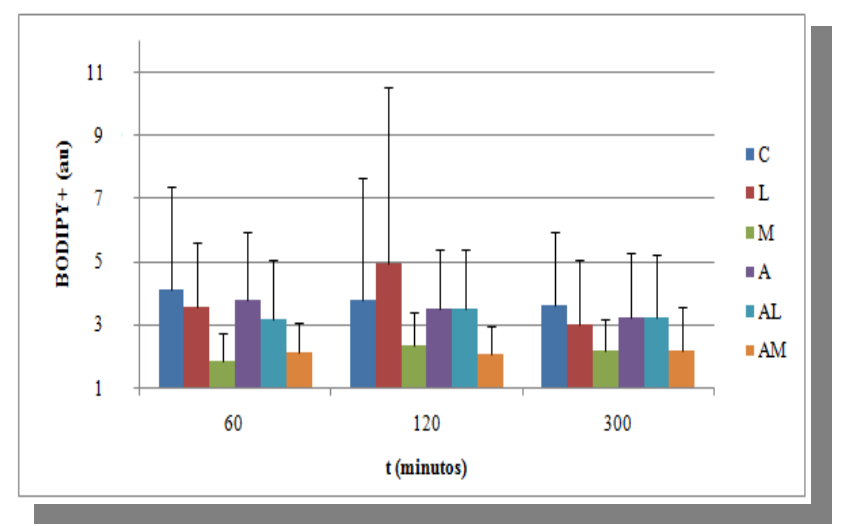

Legenda 28 - Controle (C- meio FIV), L-NAME (L-1 mM de L-NAME em meio FIV), Azul de metileno (M-100 mM de Azul de metileno em meio FIV), L-arginina (A-10 mM de L-arginina em meio FIV), Larginina + L-NAME (AL-10 mM de L-arginina+1 mM de L-NAME em meio FIV) e L-arginina + Azul de metileno (AM-10 mM de L-arginina $+100 \mathrm{mM}$ de Azul de metileno) 
Fonte: (FRANCO-SILVA, 2013)

Figura 27 - Médias \pm desvios padrão do efeito dos tratamentos (C, L, M, A, AL e AM) na peroxidação lipídica das membranas espermáticas em células íntegras (BODI+, a.u.)

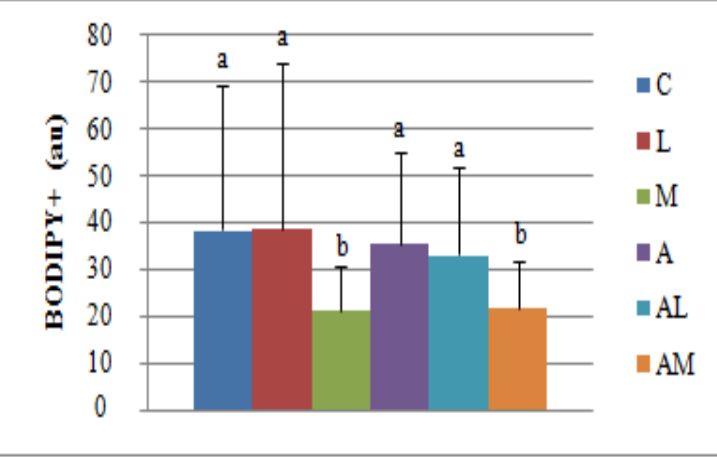

Legenda 29 - Controle (C- meio FIV), L-NAME (L-1 mM de L-NAME em meio FIV), Azul de metileno (M-100 mM de Azul de metileno em meio FIV), L-arginina (A-10 mM de L-arginina em meio FIV), Larginina + L-NAME (AL-10 mM de L-arginina+1 mM de L-NAME em meio FIV) e L-arginina + Azul de metileno (AM-10 mM de L-arginina $+100 \mathrm{mM}$ de Azul de metileno)

Fonte: (FRANCO-SILVA, 2013) 


\section{8 - DISCUSSÃO}

O NO desempenha um papel importante na regulação da motilidade (LEWIS et al., 1996), capacitação (HELLSTROM et al., 1994) e reação acrossômica em espermatozoides de mamíferos (REVELLI et al., 2001). Neste sentido, este estudo demonstrou a importância do papel do NO endógeno na fisiologia do espermatozoide equino criopreservado.

As funções do NO até o momento descobertas são complexas e antagônicas (FLORA FILHO; ZILBERSTEIN, 2000). Uma característica marcante desta molécula é a sua capacidade de ser benéfica ou potencialmente tóxica de acordo com a concentração ou depuração tecidual. Devido a esta caracteristica, alguns autores como Schmidt (1994), denominam apropriadamente o NO como uma "faca de dois gumes" (FLORA FILHO; ZILBERSTEIN, 2000). O NO é um importante mensageiro intercelular nos mamíferos superiores, porém, pelas suas características químicas de alta difusibilidade, sua sinalização é exercida diretamente em nível intracelular, sem receptores transmembranosos. Assim, o organismo utiliza o NO em funções fisiológicas em que é necessária uma resposta rápida. O NO também faz parte do arsenal de defesa do organismo com poder microbicida. Nestes casos, existe um tênue limite de concentração tissular entre a não-toxicidade às células e a toxicidade necessária para ação antimicrobiana. A determinação destas concentrações tissulares relativas permanecem um segredo da natureza (FLORA FILHO; ZILBERSTEIN, 2000).

A demonstração da produção de NO ainda é difícil, sendo quase sempre feita de maneira indireta (LAMPIAO; STRIJDOM; PLESSIS, 2005; FERRUSOLA et al., 2009) Pesquisas não demonstraram o NO propriamente dito devido sua evanescência e consideraram a concentração de nitrito e nitrato como prova de sua produção (ROY; ATREJA, 2007) Outro método de demonstrar o NO é a substituição do substrato por um análogo (L-NNA ou L-NMMA ou L-NAME) sendo a ausência do efeito pesquisado imputado pela não formação de NO devido ao bloqueio da reação da L-arginina à Lcitrulina (FLORA FILHO; ZILBERSTEIN, 2000).

$\mathrm{O}$ presente estudo demonstrou que quando os espermatozoides equinos criopreservados foram incubados na presença de um removedor do NO (azul de metileno - $100 \mathrm{mM}$ ), houve uma redução total ou parcial de todas as características da 
motilidade e da porcentagem de células hiperativadas em todos os tempos de incubação $(0,60,120,300$ min.) nos tratamentos L-arginina + azul de metileno e azul de melileno (AM e M). Estes resultados indicam que este radical livre desempenha um papel importante na regulação, na manutenção da motilidade, e possívelmente na hiperativação dos espermatozoides equinos criopreservados. Uma resposta plausível para que ocorra este evento pode estar relacionada com ação do azul de metileno em inibir indiretamente a produção de NO via guanilato ciclase, já que ele é amplamente utilizado para a inibição de guanilato monofostato ciclíca (GMPc) (MURAT et al., 1978). O grupo heme da guanilato ciclase solúvel parece ser o local alvo de ação do azul de metileno para impedir esta estimulação (MURAT et al., 1978). Um estudo semelhante realizado em espermatozoides de humanos verificou que o azul de metileno inibiu a motilidade progressiva e causou reduções da VAP, VCL, VSL, ALH e LIN, porém, não foi evidenciada a inibição da BCF (DONELLY et al., 1997), ao contrário do presente estudo.

No entanto, se por um lado o azul de metileno inibiu total ou parcialmente a motilidade dos espermatozoides equinos criopreservados, por outro, a integridade de membrana plasmática e acrossomal manteve-se preservada. Estes resultados corroboram com os dados de Wood et al. (2006), onde observaram que a incubação de espermatozoides humanos, com o azul de metileno, a uma concentração equivalente de $1,25 \mathrm{mg} / \mathrm{mL}$, não afetou a viabilidade (integridade de membrana) espermática, e após $4 \mathrm{~h}$ de incubação, $82 \%$ dos espermatozoides permaneceram com membrana plasmática integra. Rodriguez et al. (2005) também identificaram que a adição do removedor de NO baixou significativamente os níveis de reação acrossômica em espermatozoides de bovinos capacitados com heparina, semelhante aos resultados do presente estudo. Estes resultados indicam que a remoção do NO através da adição do azul de metileno reduz total ou parcialmente os padrões de motilidade e hiperativação espermática, mas, por outro lado, mantém a integridade de membrana plasmática e acrossomal. Possivelmente esta inibição ocorre através do mecanismo que inibi a guanilato ciclase impedindo a geração de NO. Com os resultados obtidos foi questionado se o efeito do azul de metileno na motilidade das células espermáticas é reversível. Portanto isso sugere a necessidade de mais estudos para desvendar esta questão levantada em relação a reversibilidade da inibição pelo azul de metileno.

No presente estudo quantificamos indiretamente por citometria de fluxo a presença do NO em espermatozoides equinos criopreservados através do uso da sonda 
fluorescente DAF e percebemos que este radical livre é removido dos espermatozoides pela ação do azul de metileno, o que reitera e confirma a hipótese de que os espermatozoides equinos criopreservados produzem NO (FERRUSOLA et al., 2009a).

No experimento de Ferrusola et al. (2009a), foram encontradas correlações positivas entre a produção de NO e algumas características do sêmen pós-descongelação relacionadas com a qualidade do espermatozoide, como a integridade de membrana e padrões de motilidade [espermatozoides mortos $(-0,532 ; \mathrm{P}<0,01)$, motilidade progressiva $(0,562 ; \mathrm{P}<0,01)$, motilidade total $(0,464 ; \mathrm{P}<0,05)$, velocidade circular $(0,511 ; \mathrm{P}<0,01)]$. Além disso, foi observada uma variação significativa de garanhão para garanhão no tocante a produção de NO, em condições de criopreservação, evidenciando um aumento de sua produção, principalmente nos garanhões com boas características espermáticas pós-descongelação. O que nos leva a considerar que o NO tem um papel positivo na fisiologia do espermatozoide equino.

Neste experimento identificamos que as variáveis MT e MP apresentaram-se reduzidas no tempo 0 min. nos grupos que receberam L-arginina (10 mM; A e AL) quando comparadas com os outros tempos e tratamentos. Presumimos que esta redução no tempo 0 min. possa ter uma relação com um aumento da síntese de NO. Entretanto, é possível que a produção de NO tenha sido súbita e próxima ao momento da adição da L-arginina, não permitindo a deteção do aumento deste radical livre com a metodologia empregada.

A influência do NO exógeno sobre a motilidade, viabilidade, metabolismo e mecanismos que conduzem à fertilização tem sido estudada em várias espécies: humanos (ZINI; LAMIRANDE; GAGNON, 1995); camundongos (HERRERO et al., 1999); bovinos (O'FLAHERTY; RODRIGUEZ; SRIVASTAVA, 2004) e búfalos (ROY; ATREJA, 2007). Entretanto, existe na literatura uma inconsistência dos dados referentes ao efeito do óxido nítrico na motilidade. Por exemplo, ZINI; LAMIRANDE; GAGNON (1995) relataram que altas concentrações de doadores de NO (dietilaminaNONOate ou espermina-NONOate; 0,3 e $1 \mathrm{mM}$ ) reduziram a motilidade espermática, entretanto, baixas concentrações desses doadores $(0,1 \mathrm{mM})$ não tiveram efeito sobre a motilidade e hiperativação espermática, porém, foi observado um aumento significativo da capacitação. Nossos resultados de motilidade em espermatozoides de equinos criopreservados contradizem os obtidos por O'Flaherty; Rodriguez; Srivastava (2004), que observaram que a adição da L-arginina na concentação de $10 \mathrm{mM}$ manteve a motilidade em comparação com o grupo controle em espermatozoides bovinos 
criopreservados, no entanto, quando a concentração de L-arginina foi aumentada, verificaram uma redução da motilidade. Roy e Atreja, (2007) descreveram que espermatozoides de búfalos tratados com a L-arginina aumentaram a produção de NO (nitrato e nitrito), sendo este aumento tempo-dependente.

Supomos que no atual estudo, a concentração $10 \mathrm{mM}$ de L-arginina, foi suficiente para desencadear um aumento súbito na produção de NO, que por sua vez causou uma inibição transitória da motilidade (possível efeito citotóxico), porém, não afetando a integridade de membrana.

Em experimento realizado com espermatozoides humanos observaram que as baixas concentrações de NO (nitroprussiato de sódio 25-100 nM) aumentam a motilidade (HELLSTROM et al.; 1994) podendo ser inibida pelo uso do L-NAME (1 mM) e azul de metileno (100mM) (LEWIS et al., 1996; DONNELLY et al., 1997). Por outro lado, altas concentrações de NO parecem exercer efeitos opostos sobre a motilidade de espermatozoides de humanos in vitro (ROSSELLI et al., 1995). Acreditase que concentrações elevadas de L-arginina $(40-50 \mathrm{mM})$ podem tornar os espermatozoides imóveis (O’FLAHERTY; RODRIGUEZ; SRIVASTAVA, 2004).

Segundo Weinberg et al. (1995) a magnitude e a duração de síntese de NO pelas células determina se a sua ação é patológica ou fisiológica. Altas concentrações de NO levam a uma redução da motilidade, induz a toxicidade e afeta a viabilidade (integridade) em espermatozoides. Rodriguez et al., (2005) sugerem que maiores concentrações de NO podem provocar uma citotoxicidade espermática, possivelmente devido ao efeito inibidor do óxido nítrico, quando este se liga ao grupo heme contido em enzimas da respiração celular. A nitração dessas proteínas, por exemplo, a citocromo $\mathrm{C}$ oxidase, resulta numa diminuição na produção de $\mathrm{ATP}$, necessário como fonte de energia para os espermatozoides. Além disso, o NO pode interagir com o $\mathrm{O}_{2}{ }^{\circ-}$, para formar o ânion peroxinitrito. Esta molécula, por ser muito reativa, pode agir sobre componentes citosólicos ou de membrana, como os lipídios ou proteínas com grupos tiol, afetando a integridade da membrana plasmática. Além disso, na mitocôndria, o peroxinitrito inibe complexos I e III da cadeia respiratória, alterando assim a função mitocondrial e a produção de ATP.

Nos tratamentos que receberam L-arginina (A e AL), a variável VSL apresentou-se reduzida no tempo 0 min. em relação aos grupos controle e L-NAME. No tempo 300 minutos observou-se uma redução da VSL para o grupo L-arginina+LNAME, porém este tratamento não diferiu do tratamento L-arginina. Nos demais 
tempos de incubação (60 e 120 min.) não houve diferença para a VSL entre os tratamentos. O efeito observado no tempo 0 min. provavelmente foi devida a produção de NO a partir da L-arginina, porém desconhecemos a possível causa da redução da VSL no tratamento L-arginina+L-NAME no tempo de incubação $300 \mathrm{~min}$. Cogita-se a possibilidade de um efeito tardio de um metabólito do inibidor L-NAME.

Aparentemente o inibidor L-NAME, não é um potente inibidor das NOS presentes no espermatozoide equino, uma vez que em quase todos os parâmetros avaliados o L-NAME não conseguiu inibir o efeito da L-arginina sobre a grande maioria dos parâmetros de motilidade espermática. Claramente, mais estudos são necessários. Curiosamente, detectamos efeitos sinérgicos inesperados na associação de Larginina+L-NAME. Neste tratamento, foi registrada uma redução das características do movimento espermático VCL e porcentagem de células hiperativas, e um aumento da BCF aos 120 min de incubação, indicando uma modulação da hiperativação. Uma hipótese levantada para explicar este resultado pode ser devido a uma possível ação do L-NAME sobre NOS específicas presentes apenas na mitocôndria ou na calda do espermatozóide equino afetando negativamentamente a modulação do movimento espermático (hiperativação espermática). Apesar de detectarmos uma inibição da hiperativação na associação L-arginina+L-NAME, verificamos uma provável indução da reação acrossômica nas células espermáticas pela adição de L-arginina, independentemente da presença de L-NAME. Uma possível explicação para estes resultados conflitantes é que apesar da hiperativação ser considerada como parte no processo de capacitação, há evidências (em bovinos e equinos) que a hiperativação é regulada separadamente ou por uma via de sinalização do $\mathrm{Ca}^{2+}$ divergente da que regula a reação acrossomal, tendo em vista que a hiperativação ocorre mesmo quando é adicionado ao meio substâncias que bloqueiam a capacitação, como o H-89, um inibidor da proteína quinase A (PKA), e o Rp-cAMPS, antagonista do AMP cíclico (MARQUEZ; SUAREZ, 2007). Somando-se a estes achados, Colenbrander et al. (2001) descreveu em equinos que a porcentagem de células hiperativadas de uma determinada população de células com motilidade não teve mudanças quando induzidas à capacitação, concluindo que este movimento característico não pode ser usado na avaliação da capacitação.

O L-NAME é um análogo antagonista da geração de NO, que compete com a Larginina, por um número limitado de sítios de ligação na enzima NOS (ZHU et al., 
1995) e é considerado o mais potente inibidor da síntese de NO (DONELLY et al 1997). Porém, o L-NAME requer a hidrólise do grupo metil-ester por esterases celulares para se tornar um inibidor completamente funcional (L-NNA). Alguns inibidores mostram uma modesta seletividade entre isoformas da NOS. O L-NNA exibe alguma seletividade para a inibição de isoformas neuronais e endoteliais. A inibição inicial por todos os antagonistas da L-arginina é competitiva, indicando que estes inibidores ocupam o mesmo sítio de ligação da arginina/citrulina. O nível de inibição é reduzido pela presença da L-arginina e, pelo menos inicialmente, a inibição pode ser revertida pela adição de L-arginina (GRIFFITH; KILBOURN, 1996). O L-NNA não é um inibidor com base em mecanismo, mas ao invés disso, é um forte ligante, de dissociação lenta, do sítio de ligação da arginina (GRIFFITH; KILBOURN, 1996). Pelo exposto, como o L-NAME precisa ser metabolizado para gerar uma forma ativa (L-NNA), isto pode explicar porque o efeito do L-NAME foi dependente do tempo de incubação. Outra explicação é que o espermatozoide equino possa apresentar uma metabolização lenta deste inibidor, ou mesmo necessita de concentrações mais elevadas para ter uma inibição efetiva.

O NO é capaz de estimular a guanilato ciclase (HERRERO et al., 2000) e de aumentar a fosforilação do aminoácido tirosina (BAKER; AITKEN, 2004) um dos passos críticos da regulação da fisiologia espermática (FERRUSOLA et al., 2009a). Entretanto, durante a capacitação, a fosforilação do aminoácido tirosina ocorre na membrana plasmática do flagelo e na cabeça do espermatozoide provavelmente provocando mudanças conformacionais nas proteínas contribuindo para o aumento da afinidade com a ZP (PUKAZHENTHI et al., 1998) com a hiperativação (NASSAR et al., 1999 ) e com a indução da reação acrossômica (BENOFF, 1998), que são características de espermatozoides capacitados.

No atual estudo, as variáveis fosforilação do aminoácido tirosina e peroxidação de membrana plasmática foram reduzidas nos tratamentos (M e AM) sugerindo a efetiva ação do removedor de NO como um possível aditivo decapacitante no meio de criopreservação e um provável antioxidante.

Identificamos que a L-arginina não teve efeito significativo na fosforilação do aminoácido tirosina, tampouco na peroxidação lipídica. Isso pode ser um índicio que as células se encontravam préviamente capacitadas, já que houve uma redução da integridade de membrana, da fosforilação dos resíduos do aminoácido tirosina e da 
peroxidação lipídica ao longo do tempo. No entanto, observamos um aumento numérico de células com reação acrossomal (quando comparado ao controle) nos grupos que receberam L-arginina (A e AL) e uma diferença significativa entre estes tratamentos e aqueles com adição de azul de metileno (M e AM). Este achado é um forte indicativo que a L-arginina possa ter um efeito de indução da reação acrossômica.

Roy; Atreja, (2008), verificaram que a L-arginina induziu a fosforilação do aminoácido tirosina em espermatozoides de búfalos, de forma significativa e o LNAME inibiu substancialmente este processo, sugerindo que a L-arginina (5 e $10 \mathrm{mM}$ ) induz a capacitação, ou seja, uma baixa concentração de NO é necessária para induzir a capacitação e a fosforilação do aminoácido tirosina. Os resultados do atual estudo diferem sutilmente dos encontrados por estes autores, uma vez que a L-arginina não foi eficaz em induzir a fosforilação do aminoácido tirosina, porém, por outro, lado foi eficiente em induzir a reação acrossomal. Ferreira-Berbari et al. (2010), ao adicionarem $500 \mu \mathrm{M}$ de nitroprussiato de sódio ao grupo tratado com $0,1 \mathrm{M}$ de aminoguanidina, verificaram uma inibição da ação deletéria na integridade da membrana causada pela utilização de apenas $0,1 \mathrm{M}$ de aminoguanidina. No presente estudo, observou-se influência do tempo sobre a integridade de membrana, ou seja, o percentual de espermatozoides com membrana plasmática íntegra diminuiu aos $300 \mathrm{~min}$. de incubação, porém o grupo tratado com L-arginina não diferenciou do controle em nenhum dos tempos de incubação avaliados. Portanto o tratamento com L-arginina não influenciou sobre a integridade de membrana plamática e acrossomal.

O NO pode funcionar como um captador de radicais livres e inativar a $\mathrm{O}_{2}{ }^{--}$ evitando toxicidade celular. No entanto, a reação de $\mathrm{NO}$ com $\mathrm{O}_{2}{ }^{\circ}$ pode resultar na geração de peroxinitrito (ONOO-), um oxidante potente que se decompõe para formar o radical hidroxila (HOONO). Além disso, o peroxinitrito é capaz de induzir a citotoxicidade através da indução da peroxidação lipídica por nitrosação, de várias moléculas de tirosina que regulam a função da enzima na transdução de sinais e na inativação dos canais de sódio $\left(\mathrm{Na}^{+}\right)$(ROSSELLI, KELLER; DUBEY, 1998) levando a uma aumento da capacitação espermática (HERRERO; GAGNON, 2001). Isto sendo indicativo que as ações de NO na célula depende da sua concentração, estado redox celular, a abundância de metais, tióis proteicos e tióis de baixo peso molecular (glutationa) (ROSSELLI, KELLER; DUBEY, 1998). Com base nestas observações os resultados do presente estudo sugerem que o nível de NO produzido não foi elevado o 
suficiente para afetar a integridade de membrana, no entanto, foi suficiente para ativar o aminoácido tirosina por nitração. Isto justifica o fato de não detectarmos aumento da fosforilação do aminoácido tirosina e nem peroxidação lipídica. Portanto, hipotetizamos que o mecanismo de ativação da capacitação do óxido nítrico em espermatozoides equinos aparentemente se deu, neste caso, pela nitração direta dos resíduos do aminoácido tirosina, e não pela fosforilação deste.

Neste experimento verificamos que, apesar de não observarmos diferenças entre os tempos para várias características estudadas, identificamos uma tendência destas variavéis a se comportarem como em um processo de capacitação, o que é esperado visto que foram incubados em um meio de capacitação (FIV; Gardes et al., 2011). .

Esta afirmação está apoiada nos resultados dos grupos controle e tratados com L-arginina, no qual verificamos uma tendência da motilidade total e motilidade progressiva, no grupo controle, de manter a estas características aos 0 min., apresentando uma queda aos $60 \mathrm{~min}$, um aumento aos 120 min seguido de redução aos 300 min. A VAP, VCL e VSL mantiveram uma tendência de permanecerem constantes. A STR, LIN e BCF e ALH mantiveram suas características aos 0 min, apresentaram um aumento aos $60 \mathrm{~min}$, sendo reduzidas aos $120 \mathrm{~min}$, e aumentadas aos $300 \mathrm{~min}$. As célula rápidas apresentaram a mesma tendência das variáveis STR, LIN, BCF e VCL, no entanto, demonstraram-se reduzida aos $300 \mathrm{~min}$. Verificou-se uma tendência de redução das células hiperativadas aos 60 min, seguido de um aumento aos 120 min e 300 min Com relação à integridade de membrana houve uma tendência a redução aos 300 min. A produção de NO teve uma tendência de diminuir aos 300 min. As células com reação acrossômica tenderam a aumentar durante os tempos de incubação. .A fosforilação dos resíduos do aminoácido tirosina tenderam a uma leve redução aos 300 min e a peroxidação lipídica aos 120 e 300 min.

Já no grupo tratado com L-arginina verificamos tendência semelhante a observada no grupo controle na variável motilidade total, no entanto, na motilidade progressiva verificamos um marcante aumento desta característica aos 60 min que se manteve até o 120 min reduzindo aos 300 min. A VAP e a VSL apresentaram uma tendência de aumento aos 60 min que se manteve até os 120 min com uma leve queda aos 300 min. A VCL, ALH, BCF, STR e LIN mantiveram-se constantes nos tempos 60, 120 e 300 min. A porcentagem de células rápidas apresentaram uma tendência de aumento aos 60 e aos $120 \mathrm{~min}$ com posterior redução aos $300 \mathrm{~min}$. As células hiperativadas apresentaram um aumento aos 60 min e redução aos 120 e 300 min. A 
IAIM e a produção de NO tendeu a ter uma leve redução aos 300 min de incubação e as células com reação acrossômica aumentaram no tempo 300 min. As células com fosforilação do aminoácido tirosina e peroxidação lipídica apresentaram uma leve redução no decorer dos tempos de incubação.

Diante do exposto podemos considerar que o NO desempenha um papel de importância nos padrões de motilidade e hiperativação. Além disso, sua remoção do meio de incubação (azul de metileno) mantém a integridade de membrana plasmática e acrossomal além de reduzir os índices de fosforilação do aminoácido tirosina e peroxidação lipidica. Os resultados sugerem que o uso do azul de metileno, em meio de incubação, possa ser benéfico para estudos in vitro, uma vez que este removedor preserva os espermatozoides vivos por período maior e sem gasto de energia, por estarem total ou parcialmente imóveis. Deste modo, hipotetisamos que esta substância possa ser utilizada como um possível aditivo decapacitante, e provável antioxidante, no meio de criopreservação visando a proteção de espermatozóides durante biotecnologias como a criopreservação ou a sexagem. 


\section{CONCLUSÃO}

1. Na concentração de L-arginina utilizada $(10 \mathrm{mM})$ não foi possível detectar um aumento da produção de NO em espermatozoides equinos criopreservados aos 60 minutos de incubação em meio de capacitação.

2. O L-NAME na concentração utilizada $(1 \mathrm{mM})$ não é um eficiente inibidor da NOS do espermatozoides equinos, uma vez que a sua adição não inibiu a ação da L-arginina e nem a produção de NO em espermatozoides equinos criopreservados.

3. O azul de metileno é um potente removedor e inibidor da produção, e dos efeitos do NO em espermatozoides equinos incubadoss em meio de capacitação.

4. A incubação de espermatozoides equinos pós-descongelação com L-arginina no meio de incubação causou uma redução da motilidade total e progressiva, da VAP, VSL, LIN e RAP no início da incubação (0 min), porém não foi efetiva em induzir a fosforilação dos resíduos do aminoácido tirosina e nem sobre a peroxidação lipídica da membrana plasmática. No entanto, ela foi eficaz em elevar numéricamente as células com reação acrossômica.

5. O L-NAME foi efetivo apenas quando associado com a L-arginina, causando a alteração de alguns padrões de motilidade, como redução da VSL (aos $300 \mathrm{~min}$ ) e da VCL, aumento da BCF (aos 120 min) e a redução da hiperativação.

6. Ao longo do tempo houve uma tendência das células espermáticas equinas a se comportarem com características de capacitação. 


\section{REFERÊNCIAS BIBLIOGRÁFICAS}

ABDALLA, D.S.P.; SENA, K.C.M. Lipid peroxidation biomarkers in atherosclerosis. Revista de Nutrição, v. 21, p. 749-756, 2008.

ANDRADE, A.F.; ZAFFALON, F.G.; CELEGHINI, C.E.; NASCIMENTO, J.;

BRESSAN, F.F.; MARTINS, S.M.; ARRUDA, R.P. Post-thaw addition of seminal plasma reduces tyrosine phosphorylation on the surface of cryopreserved equine sperm, but does not reduce lipid peroxidation. Theriogenology , v. 77, p. 1866-1872, 2012.

AGARWALL, A.; SAID, T.M. Oxidative stress, DNA damage and apoptosis in male infertility a clinical approach. BJUI International, v. 95, p. 503-507, 2005.

AITKEN, R.J.; BUCKINGHAM, D.W.; WEST, K.M. Reactive oxygen species and human spermatozoa: analysis of the cellular mechanisms involved in luminol- and lucigenin- dependent chemiluminescence. Journal of Cellular Physiology, v. 151, p. 466-477, 1992.

AITKEN, R.J.; HARKISS, D.; KNOX, W.; PATERSON, M.; IRVINE, D.S. A novel signal transduction cascade in capacitating human spermatozoa characterized by a redox-regulated, cAMP-mediated induction of tyrosine phosphorylation. Journal of Cell Science, v. 111, p. 645-656, 1998.

ALM, H.; CHOI, Y.H.; LOVE, L.; HELEIL, B.; TORNER, H.; HINRICHS, K. Holding bovine oocytes in the absence of maturation inhibitors: Kinetics of in vitro maturation and effect on blastocyst development after in vitro fertilization. Theriogenology, v. 70, p. 1024-1029, 2008.

ALVAREZ, J.G.; STOREY, B.T. Spontaneous lipid peroxidation in rabbit epididymal spermatozoa: Its effects on sperm motility. Biology of Reproduction, v. 27, p. 11021108, 1982.

AMMON, H. P.T.; WAHL, M. A. Pharmacology of curcumin. Planta Medica, v. 57, p. $1-7,1991$.

ARRUDA, R.P. Avaliação dos efeitos de diluidores e crioprotetores para o espermatozoide equino pelo uso de microscopia de epifluorescência, citometria de fluxo, análises computadorizadas da motilidade (CASA) e da morfometria (ASMA). 2000. 121 f. Tese (Livre Docência) - Faculdade de Medicina Veterinária e Zootecnia, Universidade de São Paulo, São Paulo.

AUSTIN, C.R. Observations on the penetration of the sperm into the mammalian egg. Australian Journal Science Research, v. 4, 581-596, 1951.

AUSTIN, C.R. The capacitation of the mammalian sperm. Nature, v. 170, p. 326, 1952. 
AYAJIKI, K.; OKAMURA, T.; TODA, N. Nitric oxide mediates, and acetylcholine modulates, neurally induced relaxation of bovine cerebral arteries. Neuroscience, v. 54, p. 819-825, 1993.

AZUMA, H.; ISHIKAWA, M.; SEKIZAKI, S. Endothelium-dependent inhibition of platelet aggregation. Britshi. Journal Pharmacology, v. 88, p. 411-415, 2012.

BAKER, M. A.; AITKEN, R. J. The importance of redox regulated pathways in sperm cell biology. Molecular and Cellular Endocrinology, v. 216, p. 47-54, 2004.

BALL, B. A. Oxidative stress, osmotic stress and apoptosis: Impacts on sperm function and preservation in the horse. Animal Reproduction Science, v. 107, p. 257-267, 2008.

BALL, B.A.; GRAVANCE, C.G.; MEDINA, V.; BAUMBER, J.; LIU, I.K.M. Catalase activity in equine semen. American Journal Veterinary Research, v. 61, p. 10261030,2000 .

BALL, B.A.; VO, A.T.; BAUMBER, J. Generation of reactive oxygen species by equine spermatozoa. American Journal Veterinary Research, v. 62, p. 508-515, 2001.

BALÃO DA SILVA, C.M.; MACÍAS-GARCÍA, B.; MIRÓ-MORÁN, A.; GONZÁLEZ-FERNÁNDEZ, L.; MORILLO-RODRIGUEZ, A.; FERRUSOLA, C.O.; GALLARDO-BOLAÑOS, J.M.; STILWELL, G.; TAPIA, J.A.; PENÃ, F.J. Melatonin reduces lipid peroxidation and apoptotic-like changes in stallion spermatozoa. Journal of Pineal Research, v. 51, p. 172-179, 2011.

BAUMBER, J., BALL, B.A. Determination of glutathione peroxidase and superoxide dismutase-like activities in equine spermatozoa, seminal plasma, and reproductive tissues. American Journal Veterinary Research, v. 66, p. 1415-1419. 2005.

BAUMBER, J.; BALL, B.A.; LINFOR,J.J.; MEYERS, S.A. Reactive oxygen species and cryopreservation promote DNA fragmentation in equine spermatozoa. Journal of. Andrology, v. 24, p. 621-628, 2003.

BAUMBER, J.; BALL B.A.; GRAVANCE, C.G.; MEDINA, V.; DAVIES MOREL, M.C.G. The effect of reactive oxygen species on equine sperm motility, viability, acrosomal integrity, mitochondrial membrane potential and membrane lipid peroxidation. Jounal of Andrology, v. 21, p. 895-902, 2000.

BENOFF, S. Modelling human sperm-egg interactions in vitro: signal transduction pathways regulating the acrosome reaction. Molecular Human Reproduction, v. 4, p. 453-471, 1998.

BOATMAN, D.E.; ROBBINS, R.S. Bicarbonate: carbon dioxide regulation of sperm capacitation, hyperactivated motility, and acrosome reactions. Biology of Reproduction, v. 44, p. 806-813, 1991. 
BOGLE, R.G.; MONCADA, S.; PEARSON, J.D.; MANN, G.E. Identification of inhibitors of nitric oxide synthase that do not interact with the endothelial cell Larginine transporter. British Journal of Pharmacology, v. 105, p. 768-770, 1992.

BOX, H.C.; FREUND, H.G.; BUDZINSKI, E.E.; WALLACE, J.G.; MACCUBBIN, A.E. Free radical induced double base lesions. Radiat Research, v. 141, p. 91-94, 1995.

BREDT, D.S.; GLATT, C.E.; HWANG, P.M.; FOTUHI, M.; DAWSON, T.M.; SNYDER, S.H. Nitric oxide synthase protein and mRNA are discretely localized in neuronal populations of the mammalian CNS together with NADPH diaphorase.

Journal Neuron, v. 7, p. 615-624, 1991.

BREDT, D.S.; HWANG, P.M.; SNYDER, S.H. Localization of nitric oxide synthase indicating a neural role for nitric oxide. Nature, v. 25, p. 768-770, 1990.

BREDT, D.S.; SNYDER, S.H. Isolamento da enzima óxido nítrico sintase, uma enzima que requer calmodulina. Proceedings of the National Academy of Sciences, v. 85 p. 682-685, 1990.

BREDT, D.S.; SNYDER; S.H. Nitric oxide mediates glutamate-linked enhancement of cGMP levels in the cerebellum. Proceedings of the National Academy of Sciences, v. 86, p. 9030-9033, 1989.

CALVO, L.; VANTMAN, D.; BANKS, S.; TEZON, J.; KOUKOULIS, G.;

DENNISON, L.; SHERINS, R. Follicular fluid-induced acrosome reaction distinguishes a subgroup of men with unexplained infertility not identified by semen analysis.

Fertility and Sterility, v. 52, p. 1048-1054, 1989.

CARLSON, A.E.; HILLE, B.; BABCOCK, D.F. External $\mathrm{Ca}^{2+}$ acts upstream of adenylyl cyclase SACY in the bicarbonate signaled activation of sperm motility.

Developmental Biology, v. 312, p. 183-192, 2007.

CASAO, A.; MENDOZA, N.; PÉREZ-PÉ, R.; PATRICIA, G.;JOSÉ-ALFONSO A.; FERNANDO, F.; CEBRIÁN-PÉREZ, J.A.; MUINO-BLANCO, T. Melatonin prevents capacitation and apoptotic like changes of ram spermatozoa and increases fertility rate. Journal of Pineal Research, v. 48, p. 39- 46, 2010.

CELEGHINI, E.C.C.; ARRUDA, R.P.; ANDRADE, A.F.C.; Nascimento, J.; Raphael, C.F. Practical techniques for bovine sperm simultaneous fluorimetric assessment of plasma, acrosomal and mitochondrial membranes. Reproduction in Domestic Animals, v. 42, n. 5, p. 479-488, 2007.

CENDAN, J.C.; TOPPING, D.L.; PRUITT, J.; SNOWDY, S.; COPELAND III, E.M.; LIND, D.S. Inflammatory mediators stimulate arginine transport and arginine-derived nitric oxide production in a murine breast cancer cell line. Journal of Surgical Research, v. 60, p. 284-288, 1996.

CHANG, H.; SUAREZ, S.S. Rethinking the relationship between hyperactivation and chemotaxis in mammalian sperm. Biology of Reproduction, v. 83, p. 507-513, 2010. 
CHANG, M.C. Fertilizing capacity of spermatozoa deposited into the fallopian tubes. Nature, v. 168, p. 697-698, 1951.

CORMIER, N.; SIRARD, M.A.; BEILEY, J.L. Premature capacitation of bovine spermatozoa is initiated by cryopreservation. Journal of Andrology, v. 18 p. 461-468, 1997.

CROSS, N. L. Role of cholesterol in sperm capacitation. Biology of Reproduction, v.59, p. 7-11, 1998.

DAN, J.C. Studies on the acrosome. II. Acrosome reaction in starfish spermatozoa. The Biological Bulletin, v. 107 p. 203-218, 1954.

de LAMIRANDE, E.; GAGNON, C. Reactive oxygen species and human spermatozoa. II. depletion of adenosine triphosphate plays an important role in the inhibition of sperm motility. Journal of Andrology, v. 13, p. 379-386, 1992.

de LAMIRANDE, E.; HARAKAT, A.; GAGNON, C. Human sperm capacitation induced by biological fluids and progesterone, but not by NADH or NADPH, is associated with the production of superoxide anion. Jounal of Andrology, v.19, p. 215225, 1998.

DE VERA, M.E.; SHAPIRO, R.A.; NUSSLER, A.K.; MUDGETT, J.S.; SIMMONS, R.L.; MORRIS, S.M.; BILLIAR, T.R.; GELLER, D.A.Transcriptional regulation of human inducible nitric oxide synthase (NOS2) gene by cytokines: initial analysis of the human NOS2 promoter. Proceedings of the National Academy of Sciences, v. 93, p. 1054-1059, 1996.

DEGUCHI, T.; YOSHIOKA, K. L-Arginine identified as an endogenous activator for soluble guanylate cyclase from neuroblastoma cells. Journal of Biological Chemistry, v. 257, p. 10147-10151, 1982.

DIXIT, V.D.; PARVIZI, N. Nitric oxide and the control of reproduction. Animal Reproduction Science, v. 65, p. 1-16, 2001.

DONNELLY, E.T.; LEWIS, S.E.; THOMPSON, W.; CHAKRAVARTHY, U. Sperm nitric oxide and motility: the effects of nitric oxide synthase stimulation and inhibition, Molecular Human Reproduction, v. 3, p. 755-762, 1997.

FELDMAN, P.L.; GRIFFITH, O.W.; HONG, H.; STUEHR, D.J. Irreversible inactivation of macrophage and brain nitric oxide synthase by L-NG-methylarginine requires NADPH-dependent hydroxylation. Journal of Medical Chemistry, v. 36, p. 491-496, 1993.

FENG, B.; BHATTACHARYYA, A.; YANAGIMACHI, R. $\mathrm{Ca}^{2+}$ is essential for the motility of plasma membrane-intact but not of demembranated hamster spermatozoa. Andrologia, v. 20, p. 155-162, 1988.

FERREIRA-BERBARI, J.B.P.; CALDAS-BUSSIERE, M.C.; PAES DE CARVALHO, C.S.; descrever os demais autoresQuirino. Effect of inhibition of inducible nitric oxide 
synthase on in vitro capacitation of bovine spermatozoa. Arquivo Brasileiro de Medicina Veteteinaria e Zootecnia, v. 62, p. 511-520, 2010.

FERRUSOLA, C.O.; GONZÁLEZ FERNÁNDEZ, L.; MACÍAS GARCÍA,B.; SALAZAR-SANDOVAL,C.; MORILLO RODRÍGUEZ, A.; RODRÍGUEZMARTINEZ, H.; TAPIA, J.A.; PENÃ, F.J. Effect of cryopreservation on nitric oxide production by stallion spermatozoa. Biology of Reproduction, v. 81, p. 1106-1111, 2009a.

FERRUSOLA, C.O.; GONZÁLEZ FERNÁNDEZ, L.; MORRELL, J.M.; SALAZARSANDOVAL,C.; MACÍAS GARCÍA,B.; RODRÍGUEZ-MARTINEZ, H.; TAPIA, J.A.; PENÃ, F.J. Lipid peroxidation, assessed with BODIPY-C11, increases after cryopreservation of stallion spermatozoa, is stallion-dependent and is related to apoptotic-like changes. Reproduction Research, v. 38, p. 55-63, 2009 b.

FLORA FILHO, R.; ZILBERSTEIN, B. Óxido nítrico: o simples mensageiro percorrendo a complexidade, metabolismo, síntese e funções. Revista da Associação Médica Brasileira, 2000. Doi: 10.1590/S0104-42302000000300012. Disponível em: <http://www.scielo.br/scielo.php?script=sci_arttext\&pid=S0104-42302000000300012>. Acesso em: 06/ 09/ 2012.

FORERO-GONZALEZ, R. A.; CELEGHINI, E. C. C.; RAPHAEL, C. F.; ANDRADE, A. F. C.; BRESSAN, F. F.; ARRUDA, R. P. Effects of bovine sperm cryopreservation using different freezing techniques and cryoprotective agents on plasma, acrosomal and mitochondrial membranes. Andrologia, v. 44, p. 154-159, 2012.

FURFINE, E.S.; HARMON, M.F.; PAITH, J.E.; KNOWLES, R.G.; SALTER, M.; KIFF, R.J.; DUFFY, C.; HAZELWOOD, R.; OPLINGER, J.A.; GARVEY, E.P. Potent and selective inhibition of human nitric oxide synthases. Selective inhibition of neuronal nitric oxide synthase by S methyl-L-thiocitrulline and S-ethyl-Lthiocitrulline. Journal of Biological Chemistry, v. 269, p. 26677- 26683, 1994.

GADELLA, B. M.; RATHI, R.; BROUWERS, J. F.; STOUT, T. A.; COLENBRANDER, B. Capacitation and the acrosome reaction in equine sperm. Animal Reproduction Science, v. 68, p. 249-265, 2001.

GADELLA, B.M.; EVANS, J.P. Membrane fusions during mammalian fertilization. Advances in Experimental Medicine and Biology, v. 713, p. 65-80, 2011.

GALANTINO-HOMER, H. L.; FLORMAN, H. M.; STOREY, B. T.; DOBRINSKI, I.; KOPF, G. S. Bovine sperm capacitation: assessment of phosphodiesteraseactivity and intracellular alkalinization on capacitationassociatedprotein tyrosine phosphorylation. Molecular Reproduction and Development, v. 67 p. 487-500, 2004.

GARDES, T.P.; ARRUDA, R.P.; SILVA, D.F.; RODRIGUEZ, R.N.C.; NASCIMENTO, J.; LEMES, K.M.; CARVALHO, H.F.; ANDRADE, A.F.C. Efficiency comparison of media for the equine sperm capacitation through flow cytometry analysis. Acta Scientiae Veterinariae, 2011;39 (Suppl 1). Anais: 25th Annual Meeting SBTE-Brazil. Cumbuco, 2011. 
GARTHWAITE, J.; GARTHWAITE, G. Cellular origins ofcyclic GMP responsesto excitatory amino acid receptor agonists in rat cerebellum in vitro. Journal of Neurochemistry, v. 48, p. 29-39, 2006.

GASSNER, F.X.; HOPWOOD, M.L. Seminal amino acid and carbohydrate pattern of bulls with normal and abnormal testes function. Proceedings of the Society for Experimental Biology and Medicine, v. 81, p. 37-43, 1952.

GERZER, R.; HOFMANN, F.; SCHULTZ, G. Purification of a soluble, sodiumnitroprusside-stimulated guanylate cyclase from bovine lung. European Journal of Biochemistry, v. 116, p. 479-486, 1981.

GRIFFITH, O.W.; KILBOURN, R.G. Nitric oxide synthase inhibitors: Amino acids. Methods in Enzymology, v. 268, p. 375-392, 1996.

GRIVEAU, J.F.; RENARD, P.; LE LANNOU, D. An in vitro promoting role of human sperm capacitation for hydrogen peroxide. Journal of Andrology, v. 17, p. 300-307, 1994.

GRIVEAU, J.F.; RENARD, P.; LE LANNOU, D. Superoxide anion production by human spermatozoa as a part of the ionophore-induced acrosome reaction process.

Journal of Andrology, v. 18, p. 67-74, 1995.

GROSS, S.S.; STUEHR, D.J.; AISAKA, K.; JAFFE, E.A.; LEVI, R.; GRIFFITH, O.W. Macrophage and endothelial cell nitric oxide synthase: cell-type selective inhibition by NG-aminoarginine, NG-nitroarginine and NG-methylarginine. Biochemical and Biophysical Research Communications, v. 170, 96-103, 1990.

GROSS, S.S.; WOLIN, M.S. Nitric oxide: pathophysiological mechanisms, Annual Review of Physiology, v. 57, p. 737-769, 1955.

GRUETTER, C.A.; BARRY, B.K.; MCNAMARA, D.B.; GRUETTER, D.Y.; KADOWITZ, P.J.; IGNARRO, L. Relaxation of bovine coronary artery and activation of coronary arterial guanyiate cyclase by nitric oxide, nitroprusside and a carcinogenic nitrosoamine. Journal of Cyclic Nucleotide Research , v. 5, p. 211-224, 1979.

GUERRA, M. M. P.; EVANS, G.; MAXWELL, W. M. C. Papel de oxidantes e antioxidantes na andrologia. Revista Brasileira de Reprodução Animal, v. 28, p. 187 $195,2004$.

HAMMERSTEDT, R.H.; GRAHAM, J.K.; NOLAN, J.P. Cryopreservation of mammalian sperm: what we ask them to survive? Journal of Andrology, v. 11, p. 7388, 1990 .

HAMMMERSTEDT, R.H. Maintenance of bioenergetic balance in sperm and prevention of lipid peroxidation: a review of the effect on design of storage preservation systems. Journal of Reproduction and Fertility, v. 5, p. 675-690, 1993. 
HAMNER, C.E.; WILLIAMS, W.L. Identification of sperm stimulating factor of rabbit oviduct fluid. Proceedings of the Society for Experimental Biology and Medicine, v. 117, p. 240-243, 1964.

HARRISON, R.A.P.; MILLER, N.G.A. cAMP-dependent protein kinase control of plasma membrane lipid architecture in boar sperm. Molecular Reproduction and Development, v. 55, p. 220-228, 2000.

HARRISON, R.A.P.; ASHWORTH, P.J.C.; MILLER, N.G.A. Bicarbonate/CO ${ }_{2}$, an effector of capacitation, induces a rapid and reversible change in the lipid architecture of boar sperm plasma membranes. Molecular Reproduction and Development, v. 45, p. 378-391, 1996.

HARRISON, R.A.P.; GADELLA, B.M. Bicarbonate-induced membrane processing in sperm capacitation. Theriogenology, v. 63, p. 342-351, 2005.

HELLSTROM, W.J.; BELL, M.; WANG, R.; SIKKA, S.C. Effect of sodium nitroprusside on sperm motility viability and lipid peroxidation. Fertilit and Sterility, v. 61, p. 1117-1122, 1994.

HERRERO, M.B.; de LAMIRANDE, E.; GAGNON, C. Nitric oxide regulates human sperm capacitation and protein-tyrosine phosphorylation in vitro. Biology of Reproduction, v. 61, 575-581, 1999.

HERRERO, M.B.; CEBRAL, E.; BOQUET, M.; VIGGIANO, J.M.; VITULLO, A.; GIMENO, M.A. Effect of nitric oxide on muse sperm hyperactivation. Acta Physiologica, Pharmacologica et Therapeutica Latino Americana, v. 44, p. 65-69, 1994.

HERRERO, M.B.; CHATTERJEE, S.; LEFIEVRE, L.; de LAMIRANDE, E.; GAGNON, C. Nitric oxide interacts with the cAMP pathway to modulate capacitation of human spermatozoa. Free Radic Biolology and Medicine, v. 29, p. 522-536, 2000.

HERRERO, M.B.; GAGNON, C. Nitric oxide: a novel mediator review of sperm function. Journal of Andrology, v. 22, p. 349-356, 2001.

HERRERO, M.B.; PEREZ MARTINEZ, S.; VIGGIANO, J.M.; POLAK, J.M.; GIMENO, M.F. Localization by indirect immunofluorescence of nitric oxide synthasein mouse and human spermatozoa. Reproduction Fertility and Development, v.8, p. 931-934, 1996.

HERRERO, M.B.; VIGGIANO, J.M.; PEREZ MARTINEZ, S.; DE GIMENO, M.F. Evidence that nitric oxide synthase is involved in progesteroneinduced acrosomal exocytosis in mouse spermatozoa. Reproduction Fertility and Development, v. 9, p. 433-439, 1997.

HERRERO, M.B.; de LAMIRANDE, E.; GAGNON, C. Nitric oxide regulates human sperm capacitation and protein-tyrosine phosphorylation in vitro. Biology of Reproduction, v. 61 p.575-581, 1999. 
HIBBS, J.B.; TAINTOR, R.R.; VAVRIN, Z. Macrophage cytotoxicity: role for Larginine deiminase and imino nitrogen oxidation to nitrite, Science, v. 235, p. 473-476, 1987.

HINRICHS, K.; SHAVAHN, C.; LOUX, B.S. Hyperactivated sperm motility: Are equine sperm different? Journal of Equine Veterinary, v. 32, p. 441-444, 2012.

HOBBS, A.J. Soluble guanylate cyclase: the forgotten sibling. Pharmacological Sciences, v. 18, p. 484-491, 1997.

HOLT, W.V.; HARRISON, R.A. Bicarbonate stimulation of boar sperm motility via a protein kinase A-dependent pathway: between-cell and between-ejaculate differences are not due to deficiencies in protein kinase A activation. Journal of Andrology, v. 23, p. 557-565, 2002.

HOLT, L.E.; ALBANESI, A.A. Observation of amino acids deficiencies in man. Transactions of the Association of American Physicians, v. 58, p. 143-156, 1994.

ICKOWICZ, D.; FINKELSTEIN, M.; BREITBART, H. Mechanism of sperm capacitation and the acrosome reaction: role of protein kinases. Asian Journal of Andrology, v. 14, p. 816-821, 2012.

IGNARRO, L.J. Heme-dependent activation of guanylate cyclase by nitric oxide: a novel signal transduction mechanism. Blood Vessels, v. 28, p. 67-73, 1991.

IGNARRO, L.J.; LIPTON, H.; EDWARDS, J.C.; BARICOS,W.H.; HYMAN, A.L.; KADOWITZ, P.J.; GRUETTER, C.A. Mechanism of vascular smooth muscle relaxation by organic nitrates, nitrites, nitroprusside and nitric oxide: Evidence for the involvement of s-nitrosothiols as active intermediates. Journal of Pharmacology and Experimental Therapeutics, v. 218, p. 739-749, 1981.

IGNARRO, L.J. Endothelium-derived nitric oxide: pharmacology and relationship to the actions of organic nitrate esters. Pharmaceutical Research, v. 6, p. 651-659, 1989.

JABLONKA-SHARIFF, A.; OLSON, L.M. Nitric oxide is essential for optimal meiotic maturation of murine cumulus-oocyte complexes in vitro. Molecular

Reproduction and Development, v. 55, p. 412-421, 2000.

JABLONKA-SHARIFF, A.; OLSON, L.M. The role of nitric oxide in oocyte meiotic maturation and ovulation: meiotic abnormalities of endothelial nitric oxide synthase knock-out mouse oocytes. Endocrinology, v. 54, p. 2945-2954, 1998.

JIN, M.; FUJIWARA, E.; KAKIUCHI, Y.; OKABE, M.; SATOUH, Y.; SHOJI, A.B.; CHIBA, K.; HIROHASHI, N. Most fertilizing mouse spermatozoa begin their acrosome reaction before contact with the zona pellucida during in vitro fertilization. Proceedings of the National Academy of Sciences, v. 108, p. 4892-4896, 2011.

JOE, B.; LOKESH, B. R. Role of capsaicin, curcumin and dietary n-3 fatty acids in lowering the generation of reactive oxygen species in rat peritoneal macrophages.

Biochimical et Biophysical Acta, v. 1224, p. 255- 263, 1994. 
JOLY, G.A.; NARAYANAN, K.; GRIFFITH, O.W.; KILBOURN, R.G.

Characterization of the effects of two new arginine/citrulline analogues on constitutive and inducible nitric oxide synthases in rat aorta. Britsh Journal of Pharmacology, v. 115, p. 491-497, 1995.

KALAB, P.; PEKNICOVA, J.; GEUSSOVA, G.; MOOS, J. Regulation of protein tyrosine phosphorylation in boar sperm through a cAMPdependent pathway. Mololecular Reproduction and Development, v. 51, p. 304-314, 1998.

KAULA, N.; ANDREWS, A.; DURSO, C.; DIXON, C.; GRAHAM, J.K. Classification of hyperactivated spermatozoa using a robust minimum bounding square ratio algorithm. In: CONFERENCE PROCEEDINGS, ENGINEERING IN MEDICINE AND BIOLOGY SOCIETY, Anais: 31th Annual International Conference of the IEEE Engineering in Medicine and Biology Society, 2009, p. 4941-4944.

KELLER, D.W.; POLAKOSKI, K.L. L-Arginine stimulation of human sperm motility in vitro. Biology of Reproduction, v. 13, p. 154-157, 1975.

KELLY, P.A.; RITCHIE, I.M.; ARBUTHNOTT, G.W. Inhibition of neuronal nitric oxide synthase by 7-nitroindazole: effects upon local cerebral blood flow and glucose use in the rat. Journal of Cerebral Blood Flow \& Metabolism, v. 15, p. 766-773, 1995.

KOMAROV, A.; MATTSON, D.; JONES, M.M.; SINGH, P.K.; LAI, C.S. In vivo spin trapping of nitric oxide in mice. Biochemical and Biophysical Research Communications, v. 30, p. 1191-1198, 1993.

KOPF, G.S.; VISCONTI, P.E.; GALANTINO-HOMER, H. Capacitation of the mammalian spermatozoon. Advances in Biochemical Engineering / Biotechnology, v. 5, p. 83-107, 1999.

KULANAND, J.; SHIVAJI, S. Capacitation-associated changes in protein tyrosine phosphorylation, hyperactivation and acrosome reaction in hamster spermatozoa. Andrologia, v. 33, p. 95-104, 2001.

LAMIRANDE, E.; LECLERC, P.; GAGNON, C. Capacitation as a regulatory event that primes spermatozoa for the acrosome reaction and fertilization. Molecular Human Reproduction, v. 3, n. 3, p. 175-194, 1997.

LAMPIÃO, F.; STRIJDOM, H.; DU PLESSIS, S.S. Direct nitric oxide measurement in human spermatozoa: flow cytometric analysis using the fluorescent probe, diaminofluorescein. International Journal of Andrology, v. 29, p. 564-567, 2006.

LEAL, A.C.M.S.; CALDAS-BUSSIERE, M.C.; PAES DE CARVALHO, C.S.; descrever os demais autoresThe role of nitric oxide in the quality of fresh bovine spermatozoa during heparin-induced capacitation in vitro. Animal Reproduction Science, v.116, p.38-49, 2009.

LECLERC, P.; de LAMIRANDE, E.; GAGNON, C. Cyclic adenosine

3',5'monophosphate-dependent regulation of protein tyrosine phosphorylation in relation 
to human sperm capacitation and motility. Biology of Reproduction, v. 55, p. 684-692, 1996.

LECLERC, P.; de LAMIRANDE, E.; GAGNON, C. Regulation of protein-tyrosine phosphorylation and human sperm capacitation by reactive oxygen derivatives. Free Radical Biology and Medicine, v. 22, p. 643-656, 1997.

LEONE, A.; MONCADA, S.; VALLANCE, P.; CALVER, A.; COLLIER, J. Accumulation of an endogenous inhibitor of nitric oxide synthesis in chronic renal failure. The Lancet, v.339, p. 572-575, 1992.

LEWIS, S.E.M.; DONNELLY, E.T.; STERLING, E.S.L.; KENNEDY, M.S.; THOMPSON, W.; CHAKRAVARTHY, U. Nitric oxide synthase and nitrite production in human spermatozoa: evidence that endogenous nitric oxide is beneficial to sperm motility. Molecular Human Reproduction, v.2, p. 873-878, 1996.

LEYTON, L.; SALING, P. Evidence that aggregation of mouse sperm receptors by ZP3 triggers the acrosome reaction. Journal of Cell Biology, v. 108, p. 2163-2168, 1989.

LITVIN, T.N.; KAMENETSKY, A.; ZARIFYAN, J.; BUCK, L.R. Levin Kinetic properties of "soluble" adenylyl cyclase. Synergism between calcium and bicarbonate. The Journal of Biological Chemistry, v. 278, p. 15922-15926. 2003.

LOSCALZO, J.; WELCH, G. Nitric oxide and its role in the cardiovascular system.Progress in Cardiovascular Diseases, v. 38, p. 87-104, 1995.

MACK, S.R.; EVERINGHAM, J.; ZANEVELD, L.J.D. Isolation and partial characterization of the plasma membrane from human spermatozoa. Journal of Experimental Zoology, v. 240, p. 127-136, 1986.

MAEDA, H.; NOGUCHI, Y.; SATO, K.; AKAIKE, T. Enhanced vascular permeability in solid tumor is mediated by nitric oxide and inhibited by both new nitric oxide scavenger and nitric oxide synthase inhibitor.Cancer Science, v. 85, p. 331334, 1994.

MAHONY, M.C.; GWATHMEY, T. Protein tyrosine phosphorylationduring hyperactivated motility of cynomolgus monkey (Macaca fascicularis) spermatozoa. Biology of Reproduction, v.60, p. 1239-1243, 1999.

MARCOCCI, L.; PACKER, L.; DROY-LEFAIZ, M. T.; SEKAKI, A.; GARDESALBERT, M. Antioxidant action of Ginkgo biloba extracts EGb 761. Methods in Enzymology, v. 234, p. 462-475, 1994.

MARQUES, A.; ARRUDA, R. P.; CELEGHINI, E. C. C.; GOBESSO, A. A. O.; NEVES NETO, J. R. Effects of ascorbic acid and pentoxifylline on equine cryopreserved semen submitted to in vitro incubation. Theriogenology, v. 58, p. 257$260,2002$.

MARQUEZ, B.; SUAREZ, S. S. Bovine sperm hyperactivation is promoted by alkaline-stimulated $\mathrm{Ca}^{2+}$ influx. Biology of Reproduction, v. 76, p. 660-665, 2007. 
MAYER, B.; KLATT, P.; WERNER, E.R.; SCHMIDT, K. Molecular mechanisms of inhibition of porcine brain nitric oxide synthase by the antinociceptive drug 7nitroindazole. Neuropharmacology, v. 33, p. 1253-1259, 1994.

MCPARTLIN, L.A.; SUAREZ, S.S.; CZAYA, C.A.; HINRICHS, K.; BEDFORD GUAUS, J.S. Hyperactivation of Stallion sperm is required for successful in vitro Fertilization of Equine Oocytes. Biology of Reproduction, v. 81, p. 199-206, 2009.

MCPARTLIN, L.A.; LITTELL, J.; MARK, E.; NELSON, J.L.; TRAVIS, A.J.; BEDFO RD-GUAUS, S.J.A. A defined medium supports changes consistent with capacitation in stallion sperm, as evidenced by increases in protein tyrosine phosphorylation and high rates of acrosomal exocytosis. Theriogenology, v. 69, p. 639-650, 2008.

MEHTA, S.; STEWART, D.J.; LANGLEBEN, D.; LEVY, R.D. Short-term pulmonary vasodilation with L-arginine in pulmonary hypertension. Circulation, v. 92, p. 1539$1545,1995$.

MEISER, H.; SCHULZ, R. Detection and localization of two constitutive NOS isoforms in bull spermatozoa. Anatomy, Histology and Embryology, v. 32, p. 21-25, 2003.

MÉNDEZ, J.D.; HERNÁNDEZ, M.P. Effect of L-arginine and polyamines on sperm motility. Ginecología y Obstetricia de México,v.61, p. 229-234, 1993.

MIROUEH, A. Effect of arginine on oligospermia. Fertilit and Sterility, v. 21, p. 217219, 1970.

MONCADA, S. Nitric oxide. Journal of Hypertension, v. 12, p. 35-39, 1994.

MONCADA, S.; PALMER, R.M.; HIGGS, E.A. Nitric oxide: physiology, pathophysiology and pharmacology. Pharmacological Reviews, v. 43, p. 109-142, 1991.

MONCADA, S.; HIGGS, A. The L-arginine-nitric oxide pathway.The New England Journal of Medicine, v. 30, v. 329, p. 2002-2012, 1993.

MOORE, P.K.; AL-SWAYEH, O.A.; CHONG, N.W.S.; EVANS, R.A.; GIBSON, A. L-NG-nitro arginine (L-NOARG), a novel, L-arginine-reversible inhibitor of endothelium-dependent vasodilatation in vitro. British Journal of Pharmacology, v. 99, p. 408-412, 1990.

MOORE, P.K.; WALLACE, P.; GAFFEN, Z.; HART, S.L.; BABBEDGE, R.C. Characterization of the novel nitric oxide synthase inhibitor 7-nitro indazole and related indazoles: antinociceptive and cardiovascular effects.

British Journalof Pharmacology, v. 110, p. 219-24, 1993. 
MURAD, F. The nitric oxide-cyclic GMP signal transduction system for intracellular and intercellular communication. Recent Progress in Hormone Research, v. 49, p. 239-248, 1994.

MURAD, F.; ISHII, K.; FORSTERMANN, U.; GORSKY, L.; KERWIN, J.F.; descrever os demais autores EDRF is an intracellular second messenger and autacoids to regulate cyclic GMP synthesis in many cells. Advances in Second Messenger Phosphoprotein and Research, v. 24, p. 441-448, 1990.

NASSAR, A.; MAHONY, M.; MORSHEDI, M.; LIN, M.-H.; SRISOMBUT,C.; OEHNINGER, S. Modulation of sperm tail protein tyrosine phosphorylation by pentoxifylline and its correlation with hyperactivated motility. Fertility and Sterility, v. 71, p. 919-923, 1999.

NAZ, R.K.; RAJESH, P.B. Role of tyrosine phosphorylation in sperm capacitation / acrosome reaction. Reproductive Biology and Endocrinology, v. 2, p. 75, 2004.

O'FLAHERTY, C.; RODRIGUEZ, P.; SRIVASTAVA, S. Arginine promotes capacitation and acrosome reaction in cryopreserved bovine spermatozoa. Biochimica et Biophysica Acta, v. 1674, p. 215-221, 2004.

OLSON, L.M.; JABLONKA-SHARIFF, A.; BELTSOS, A.N. Ovarian nitric oxide: a modulator of ovulation and oocyte maturation. In: ADASHI, F.Y. Ovulation: evolving scientific and clinical concepts. New York: Springer-Verlag,. p. 173-189, 1999.

PALMER, R.M.J.; REES, D.D.; ASHTON, D.S.; MONCADA, S. L-arginine is the physiological precursor for the formation of nitric oxide in endothelium-dependent relaxation. Biochemical and Biophysical, v. 153, p. 1251-1256, 1988.

PALMER, R.M.J.; MONCADA, S. A novel citrulline-forming enzyme implicated in the formation of nitric oxide by vascular endothelial cells. Biochemical and

Biophysical. Research Communications, v. 158, p. 348-352, 1989.

PARKS, J. E.; HAMMERSTEDT, R. H. Developmental changes occurring in the lipids of ram epididymal spermatozoa plasma membranes. Biology of Reproduction, v. 32, p. 653-668, 1985.

PARKS, J.E.; ARION, J.W.; FOOTE, R.H. Lipids of plasma membrane and outer acrosomal membrane from bovine spermatozoa. Biology of Reproduction, v. 37 p. 1249-1258, 1987.

PARKS, J.E.; LYNCH, D.V. Lipid composition and thermotropic phase behavior of boar, bull, stallion, and rooster sperm membranes. Cryobiology, v.29, p. 255-266, 1992.

PATEL, A.B.; SRIVASTAVA, S.; PHADKE, R.S.; GOVIL, G. Arginine activates glycolysis of goat epididymal spermatozoa: An NMR study. Biophysical Journal, v. 75 , p. 1522-1528, 1998. 
PFEIFFER, S.; MAYER, B.; HEMMENS, B. Nitric oxide: chemical puzzles posed by a biological messenger. Angewandte Chemie International Edition, v. 38, p. 17141731, 1999.

POMMER, A.C.; RUTLLANT, J.; MEYERS, S.A. Phosphorylation of protein tyrosine residues in fresh and cryopreserved stallion spermatozoa under capacitating conditions. Biology of Reproduction, v. 68, p. 1208-214, 2003.

PUBLICOVER, S.J.; GIOJALAS, L.C.; TEVES, M.E.; DE OLIVEIRA, G.S.; GARCIA. A.A.; BARRATT, C.L.; HARPER, C.V. Ca ${ }^{2+}$ signalling in the control of motility and guidance in mammalian sperm. Frontiers in Bioscience, v. 13, p. 56235637, 2008.

PUKAZHENTHI, B.S.; WILDT, D.E.; OTTINGER, M.A.; HOWARD, J. Inhibition of domestic cat spermatozoa acrosome reaction and zona pellucida penetration by tyrosine kinase inhibitors. Mololecular Reproduction and Development, v. 49, p. 48-57, 1998.

RADANY, E.W.; ATHERTON, R.W.; FORRESTER, I.T. Arginine uptake by rabbit spermatozoa. Archives of Biochemistry and Biophysics, v. 210, p. 770-774, 1981.

RADI, R. Nitric oxide, oxidants, and protein tyrosine nitration. Proceedings, of the National Academy of Sciences, v. 101, p. 4003-4008, 2004.

RATHI, R.; COLENBRANDER, B.; BEVERS, M. M.; GADELLA, B.M. Evaluation of the in vitro capacitation of stallion spermatozoa. Biology of Reproduction, v. 65, p. 462-470, 2001.

RATHI, R.; COLENBRANDER, B.; STOUT, T.A.; BEVERS, M.M.; GADELLA, B. M. Progesterone induces acrosome reaction in stallion spermatozoa via a protein tyrosine kinase dependent pathway. Molecular Reproduction and Development, $v$. 64, p. 120-128, 2003.

REES, D.D.; PALMER, R.M.; SCHULZ, R.; HODSON, H.F.;MONCADA, S. Characterization of three inhibitors of endothelial nitric oxide synthase in vitro and in vivo. British Journal of Pharmacology, v. 101, p. 746-52, 1990.

REVELLI, A.; COSTAMAGNA, C.; MOFFA, F.; ALDIERI, E.; OCHETTI, S.; BOSIA, A.; MASSOBRIO, M.; LINDBLOM, B.; GHIGO, D. Signaling pathway of nitric oxide-induced acrosome reaction in human spermatozoa. Biology of Reproduction, v. 64, p. 1708-1712, 2001.

RODRIGUEZ, P.C.; O'FLAHERTY, C.M.; BECONI, M.T.; BEORLEGUI, N.B. Nitric oxide induces acrosome reaction in cryopreserved bovine spermatozoa. Andrologia, v. 37, p. 166-172, 2005.

ROSSELLI, M.; KELLER, P.J.; DUBEY, R.K. Role of nitric oxide in the biology physiology and pathophysiology of reproduction. Human Reproduction, v. 4, p. 3-24, 1998. 
ROSSELLI, M.; DUBEY, R. K.; IMTHURN, B.; MACAS, E.; KELLER, P.J. Andrology: effects of nitric oxide on human spermatozoa: evidence that nitric oxide decreases sperm motility and induces sperm toxicity. Human Reproduction, v. 10, p. 1786-1790, 1995.

ROY, S.C.; ATREJA, S.K. Tyrosine phosphorylation of a 38-kDa capacitationassociated buffalo (Bubalus bubalis) sperm protein is induced by L-arginine and regulated through a cAMP/PKA-independent pathway. Journal of Androlology, v. 31, p. 2-24, 2008.

SABEUR G. Effect of temperature on the contractile response of isolated rat small intestine to acetylcholine and $\mathrm{KCl}$ : calcium dependence.Archives of Physiology and Biochemistry, v. 104, p. 220-228, 1996.

SAGARE-PATIL, V.; GALVANKAR, M.; SATIYA, M.; BHANDARI, B.; GUPTA, S.K.; MODI, D. Differential concentration and time dependent effects of progesterone on kinase activity, hyperactivation and acrosome reaction in human spermatozoa.

Journal of Andrology, v. 35, p. 633-644, 2012.

SAIARIS, S.C.; BABBS, C.F.; VOORHEES III, W.D. Methvlene blue as an inhibitor of superoxide generation by xanthine oxidase. A potential new drug for the attenuation of ischemia/reperfusion injury. Biochememical Pharmacology, v. 42, p. 499-506, 1991.

SAMPER, J.C.; BEHNKE, E.J.; BYERS, A.P.; HUNTER, A.G.; CRABO, B.J. In vitro capacitation of stallion spermatozoa in calcium-free Tyrode's medium and penetration of zona-free hamster eggs.Theriogenology, v. 31, p. 875-884, 1989.

SAS. STATISTICAL ANALYSIS SYSTEM. SAS User's Guide: statistical analysis system. Release 6.12, Cary, NC: SAS Institute, 1998.

SCHAAD, N.C.; ZHANG, X.Q.; CAMPANA, A.; SCHRODERTE-SLATKINE, S. Human seminal plasma inhibits brain nitric oxide synthase activity. Human.

Reproduction, v.11, p. 561-565, 1996.

SCHWARZ, K.R.L.; PIRES, P.R.L.; ADONA, P.R.; CÂMARA DE BEM, T.H.; LEAL, C.L.V. Influence of nitric oxide during maturation on bovine oocyte meiosis and embryo development in vitro. Reproduction, Fertility and Development, v. 20p. 529536, 2008.

SCHMIDT, H.H.H.W.; WALTER, U. NO at work. Cell, v. 78, p. 919-925, 1994.

SENGOKU, K.; TAMATE, K.; YOSHIDA, T.; TAKAOKA, Y.; MIYAMOTO, T.; ISHIKAWA, M. Effects of low concentrations of nitric oxide on the zona pellucida binding ability of human spermatozoa. Fertility and Sterility, v. 69, p. 522-527, 1998.

SIDHU, K.S.; MATE, K.E.; GUNASEKERA, T.; VEAL, D.; HETHERINGTON, L.; BAKER, M.A.AITKEN, R.J. RODGER, J.C. A flow cytometric assay for global estimationof tyrosine phosphorylation associated with capacitationof spermatozoa from 
two marsupial species, thetammar wallaby (Macropus eugenii) and the brushtail possum (Trichosurus vulpecula). Reproduction, v. 127, p. 95-103, 2004.

SIGNORELLI, J.; DIAZ, E.S.; MORALES, P. Kinases, phosphatases and proteases during sperm capacitation. Cell Tissue Research, v. 349, p. 765-782, 2012.

SILVA, P. F. N.; GADELLA, B. M. Detection of damage in mammalian sperm cells. Theriogenology, v. 65, p. 958-978, 2006.

SRIMAL, R. C. Curcumin. Drugs Future, v. 12, p. 331-333, 1987.

SRIVASTAVA, S.; DESAI, P.; COUTHINHO, E.; GOVIL, G. Protective effect of larginine against lipid peroxidation in goat epididymal spermatozoa. Physiological Chemistry \& Physics \& Medical NMR, v. 32, p. 127-135, 2000.

SRIVASTAVA, S.; DESAI, P.; COUTINHO, E.; GOVIL, G. Mechanism of action of L-arginine in spermatozoa is primarily through increased biosynthesis of nitric oxide. Biology of Reproduction, v. 74, p. 954-958, 2006.

STAMLER, J.S.; SINGEL, D.J.; LOSCALZO, J. Biochemistry of nitric oxide and its redox activated forms. Science, v. 258, p. 1898-1902, 1992.

STUEHR, D.J.; CHO, H.J.; KWON, N.S.; WEISE, M.F.; NATHAN, C.F. Purification and characterization of the cytokine-induced macrophage nitric oxide synthase: an FAD- and FMN-containing flavoprotein. Proceedings on the National Academy of Science of the United States of America,v. 1, p. 7773-7777, 1991.

SUAREZ, S.S. Hyperactivated motility in sperm. Journal of Andrology, v. 17, p. 331335, 1996.

SUAREZ, S. S. Control of hyperactivation in sperm. Human Reproduction Update, v. 14, n. 6, p. 647-657, 2008.

TARDIF, S.; DUBE, C.; CHEVALIER, S.; BAILEY, J.L. Capacitation is associatedwith tyrosine phosphorylation and tyrosine kinase-like activity of pig sperm proteins. Biology of Reproduction, v. 65, p. 784-792, 2001.

TESARIK J. Comparison of acrosome reaction-inducing activities of human cumulus oophorus, follicular fluid and ionophore A23187 in human sperm populations of proven fertilizing ability in vitro. Journal of Reproduction and Fertilility, v. 7, p. 383-388, 1985.

VANACKER, M.N.J.L.; TROMP, G.R.M.M.; HAENEN, W.J.F. VANDERVIJGH, A. Flavonoids as scavengers of nitric oxide radical. Biochemical and Biophysical

Research Communication, v. 214, p. 755-759, 1995.

VEDANTAM, S.; ATREJA, S.K.; GARG, M. Angiotensin-II induced nitric oxide production during buffalo sperm capacitation and acrosome reaction. Research in Veterinary Science, v. 92, p. 207-212, 2012. 
VENEMA, R.C.; NISHIDA, K.; ALEXANDER, R.W.; HARRISON, D.G.; MURPHY, T.J. Organization of the bovine gene encoding the endothelial nitric oxide synthase.Biochimica et Biophysica Acta, v. 1218, p. 413-420, 1994.

VERSTEGEN, J.; IGUER-OUADA, M.; ONCLIM, K. Computer assisted sêmen analyzers in andrology research and veterinary practice. Theriogenology, v. 57, p.149179, 2002.

VIGNINI, A.; NANETTI, L.;BULDREGHINI, E.; MORONI, C.; RICCIARDO LAMONINA, G.; MANTERO, F.; BOSCARO, M.; MAZZANTI, L.; BALERCIA, G The production of peroxynitrite by human spermatozoa may affect sperm motility through the formation of protein nitrotyrosine. Fertily and Sterility, v. 85, p. 947- 953, 2006.

VISCONTI, P.E. Understanding the molecular basis of sperm capacitation through kinase design. Proceedings of the National Academy of Sciences, v. 106, p. 667-668, 2009.

VISCONTI, P.E.; BAILEY, J.; MOORE, G.D.; LECLERC P, CONNORS S.A.; OLDSCLARKE, P.; KOPF, G.S. Capacitation of mouse spermatozoa correlation between the capacitation state and protein tyrosine phosphorylation. Development, v. 121, p. 11291137, 1995.

VISCONTI, P.E.; BAILEY, J.L.; MOORE, G.D.; PAN, D.; OLDS-CLARKE, P.; KOPF, G.S.Capacitation of mouse spermatozoa. I. Correlation between the capacitationstate and protein tyrosine phosphorylation. Development. v. 121, p. 11291137, 2005.

VISCONTI, P.E.; GALANTINO-HOMER, H.; MOORE, G.D.; BAILEY, J.L.; NING, X.; FORNES, M.; KOPF, G.S. The Molecular Basis of Sperm Capacitation. Journal of Andrology, v. 19, p. 242-248, 1998.

VISCONTI, P.E.; WESTBROOK, V.A.; CHERTIHIN, O.; DEMARCO, I.; SLEIGHT, S.; DIEKMAN, A.B. Novel signaling pathways involved in sperm acquisition of fertilizing capacity. Journal of Reproductive Immunology, v. 53, p. 133-150, 2002.

VISCONTI, P.E.; KOPF, G.S. Regulation of protein phosphorylation during sperm capacitation. Biology of Reproduction, v. 59, p. 16, 1998.

WATSON, P.F. Recent developments and concepts in the cryopreservation of spermatozoa and the assessment of their post-thawing function. Reproduction, Fertility and Development, v. 7, p. 871-891, 1995.

WATSON, P.F. The causes of reduced fertility with cryopreserved semen. Animal Reproduction Science, v. 60-61, p. 481-492, 2000.

WEINBERG, J.B.; DOTY, E.; BONAVENTURA, J.; HANEY, A.F. Nitric oxide inhibition of human sperm motility. Fertility and Sterility, v. 64, p. 408-413, 1995. 
WEINER, D.K.; DISTELL, B.; STUDENSKI, S.; MARTINEZ, S.; LOMASNEY, L.; BONGIORNI, D. Does radiographic osteoarthritis correlate with flexibility of the lumbar spine? Journal of the American Geriatrics Society, v. 42, p. 257-263, 1994.

WENDY K. A.; COOPER, C.E.; KNOWLES, R.G. Nitric oxide synthases: structure, function and inhibition. JournalBiochemical, v. 357, 593-615, 2001.

WENNEMUTH, G.; CARLSON, A. E.; HARPER, A. J.; BABCOCK, D. F. Bicarbonate actions on flagellar and $\mathrm{Ca}^{2+}$-channel responses: initial events in sperm activation. Development, v. 130 p. 1317-1326, 2003.

WENNEMUTH, G.; WESTENBROEK, R.E.; XU, T.; HILLE, B.E.; BABCOCK, D.F. ${ }^{\mathrm{Ca}} \mathrm{V}^{2.2}$ and ${ }^{\mathrm{Ca}} \mathrm{V}^{2.3}$ (N-e R-type) $\mathrm{Ca}^{2+}$ channels in depolarization-evoked entry of $\mathrm{Ca}^{2+}$ in mouse sperm. Journal of Biological Chemistry, v. 275, p. 21210 -21217, 2000.

YANAGIMACHI, R.; PHILLIPS, D.M. The status of acrosome caps of hamster spermatozoa immediately before fertilization in vivo. Gamete Research, v.9, p. 1-19, 1984.

YANAGIMACHI, R. Mammalian fertilization. In: KNOBIL, E.; NEILL, J. D. The physiology of reproduction. New York: Raven Press, 1994. p. 189-317.

YANAGIMACHI, R.Mammalian sperm acrosome reaction: where does it begin before fertilization? Biology of Reproduction, v. 85, p. 4-5, 2011.

YANAGIMACHI, R. The movement of golden hamster spermatozoa before and after capacitation. Journal of Reproduction and Fertility, v. 23, p. 193-196, 1970.

YANAGIMACHI, R.; YANAGIMACHI, H.; ROGERS, B.J. The Use of Zona-Free Animal Ova as a Test-System for the Assessment of the Fertilizing Capacity of Human Spermatozoa. Biology of Reproduction, v. 15, p. 471-476, 1976.

YANG, Z.H.; RICHARD, V.; VON SEGESSER, L.; BAUER, E.; STULZ, P.; TURINA, M. ; LÜSCHER, T.F. Threshold concentrations of endothelin-1 potentiate contractions to norepinephrine and serotonin in human arteries. A new mechanism of vasospasm? Circulation, v. 82, p. 188-195, 1990.

YOUDIM, M.B.H.; LAVIE, L.Selective mao-a and B inhibitors, radical scavengers and nitric oxide synthase inhibitors in parkinson's disease. Life Sciences, v. 55, p. 20772082, 1994.

ZAMIR, N.; BARKAN, D.; KEYNAN, N.; NAOR, Z.; BREITBART, H. Atrial natriuretic peptide induces acrosomal exocytosis in bovine spermatozoa. American Journal of Physiologic, v. 269, p. 216-221, 1995.

ZHANG, H.; ZHENG, R.L. Possible role of nitric oxide on fertile and asthenozoospermic infertile human sperm functions. Free Radical Research,v. 25, p. 347-354, 1996. 
ZHU, P.; ZAUGG, C.E.; SIMPER, D.; HORNSTEIN, P.; ALLEGRINE, P.R.; BUSER, P.T. Bradykinin improves postischaemic recovery in the rat heart: role of high energy phosphates, nitric oxide and prostacyclin. Cardiovascular Research, v. 29, p. 658-663, 1995.

ZINI, A.; de LAMIRANDE, E.; GAGNON, C. Low levels of nitric oxide promote human sperm capacitation in vitro. Journal of Andrology, v. 16, p. 424-431, 1995. 
ANEXO - A

\section{MEIO FIV}

Quadro 1- Preparo do Meio FIV (estoque)

\begin{tabular}{|c|c|c|}
\hline Componentes & Quantidade (mM e \%) & q.s.p $(\mathrm{g} \mathrm{e} \mu \mathrm{L} / 100 \mathrm{~mL})$ \\
\hline $\mathrm{NaCl}$ & $114 \mathrm{mM}$ & $3,33 \mathrm{~g}$ \\
\hline $\mathrm{KCl}$ & $3,22 \mathrm{mM}$ & $0,12 \mathrm{~g}$ \\
\hline $\mathrm{NaH}_{2} \mathrm{PO}_{4}$ & $0,34 \mathrm{mM}$ & $0,02 \mathrm{~g}$ \\
\hline Lactato de sódio & $50 \%$ & $718,5 \mu \mathrm{L}$ \\
\hline $\mathrm{NaHCO}_{3}$ & $25 \mathrm{mM}$ & $1,05 \mathrm{~g}$ \\
\hline $\mathrm{MgCl}_{2} \cdot 6 \mathrm{H}_{2} \mathrm{O}$ & $0,5 \mathrm{mM}$ & $0,05 \mathrm{~g}$ \\
\hline $\mathrm{CaCl}_{2} .2 \mathrm{H}_{2} \mathrm{O}$ & $2,0 \mathrm{mM}$ & $0,15 \mathrm{~g}$ \\
\hline q.s.p $100 \mathrm{ml}$ de água & : 7,4 & \\
\hline
\end{tabular}

Fonte: (FRANCO-SILVA, 2013) 
Quadro 2 - Meio FIV trabalho

\begin{tabular}{|c|c|c|}
\hline Componentes & Quantidade & Armazenagem \\
\hline BSA & $6 \mathrm{mg} / \mathrm{mL}$ (pesar antes) & Geladeira \\
\hline Meio FIV & $50 \mathrm{ml}$ & Geladeira \\
\hline Gentamicina & $5 \mu \mathrm{l}(50 \mu \mathrm{g})$ & $-80^{0} \mathrm{C}$ \\
\hline $\begin{array}{c}\text { PHE (Penicilamina, } \\
\text { Hipotaurina, } \\
\text { Epinefrina) }\end{array}$ & $220 \mu \mathrm{l}$ & $-80^{\circ} \mathrm{C}$ \\
\hline Heparina & & $-80^{\circ} \mathrm{C}$ \\
\hline Piruvato & $55 \mu \mathrm{l}$ & \\
\hline
\end{tabular}

Fonte: (FRANCO-SILVA, 2013)

2 - Antibiótico

Quadro 3- Solução antibiótico

\begin{tabular}{|c|c|}
\hline Gentamicina & $5 \mu \mathrm{l}(50 \mu \mathrm{g})$ \\
\hline Solução salina filtrada $\mathbf{0 , 9 \%}$ & $100 \mathrm{Ml}$ \\
\hline
\end{tabular}

Fonte: (FRANCO-SILVA, 2013)

\section{3 - Solução PHE}


3.1 - Penicilamina $2 \mathrm{mM}$

Quadro 4- Penicilamina

\begin{tabular}{|c|c|}
\hline Componente & q.S.p 10 mL de solução \\
\hline Penicilamina & $0,0030 \mathrm{~g}$ \\
\hline Solução Fisiológica & q.s.p para $10 \mathrm{~mL}$ \\
$0,9 \%$ & \\
\hline
\end{tabular}

Fonte: (FRANCO-SILVA, 2013)

\section{Procedimento:}

Preparar a solução em vidraria limpa e estéril;

Pesar a penicilamina em papel alumínio;

Transferir para um tubo de $15 \mathrm{~mL}$ estéril;

Acrescentar aproximadamente 9,0 mL de solução fisiológica 0,9\%;

Homogeneizar por inversão;

Completar o volume para $10 \mathrm{~mL}$ em balão volumétrico;

Armazenar

3.2 - Hipotaurina $1 \mathrm{mM}$

Quadro 5- Hipotaurina $\rightarrow 1 \mathrm{mM}$ 


\begin{tabular}{|c|c|}
\hline Componente & q.s.p 10 mL de solução \\
\hline Hipotaurina & $0,0011 \mathrm{~g}$ \\
\hline Solução fisiológica $0,9 \%$ & Completar para $10 \mathrm{Ml}$ \\
\hline
\end{tabular}

Fonte: (FRANCO-SILVA, 2013)

\section{PROCEDIMENTO}

Preparar a solução em vidraria limpa e estéril;

Pesar a hipotaurina em papel alumínio;

Transferir para um tubo de $15 \mathrm{~mL}$ estéril

Acrescentar aproximadamente $9,0 \mathrm{~mL}$ de solução salina filtrada $0,9 \%$;

Homogeneizar por inversão;

Completar o volume para $10 \mathrm{~mL}$ em balão volumétrico;

Armazenar.

3.3 - Epinefrina $250 \mu \mathrm{M}$

Quadro 6 - Solução I:

\begin{tabular}{|c|c|}
\hline Lactato de sódio 60\% & $0,1650 \mathrm{~g}$ \\
\hline $\mathbf{N a}_{2} \mathbf{S}_{2} \mathbf{O}_{\mathbf{5}}$ (bissulfito de sódio) & $0,0500 \mathrm{~g}$ \\
\hline Água ultrapura & $50 \mathrm{~mL}$ \\
\hline
\end{tabular}

Fonte: (FRANCO-SILVA, 2013) 
Quadro 7- Solução II:

\begin{tabular}{|c|c|}
\hline Epinefrina & $0,00183 \mathrm{~g}$ \\
\hline Solução I & $40 \mathrm{~mL}$ \\
\hline
\end{tabular}

Fonte: (FRANCO-SILVA, 2013)

\section{PROCEDIMENTO}

* Preparar a solução em vidraria limpa e estéril;

* Pesar a epinefrina em papel alumínio;

* Transferir para um tubo de 50 mL estéril;

+ Acrescentar aproximadamente $35 \mathrm{~mL}$ da solução prévia;

* Homogeneizar por inversão;

* Completar o volume para $40 \mathrm{~mL}$ em balão volumétrico;

$\$$ Armazenar. 


\section{ANEXO B}

Quadro - 8 Ajuste do IVOS 12.3 para análise de sêmen equino

\begin{tabular}{ll}
\hline Característica & $\Lambda$ juste \\
\hline Número de imagens adquiridas (Image capture: frames) & 30 \\
Taxa de aquisição das imagens (Image caprure: frames per sec) & $80 \mathrm{~Hz}$ \\
Contraste mínimo da célula (Cell detection: minimum contrast) & 60 pixels \\
Tamanho mínimo da célula (Cell detection: minimum size) & 3 pixels \\
Tamanho para células imóveis (Defauts: cell size) & 0,32 a 1,51 \\
Intensidade para células imóveis (Defauts: cell intensity) & 30 pixels \\
Referência de VAP para células progressivas (Progressive cells: VAP) & $30,0 \mu \mathrm{m} / \mathrm{s}$ \\
Referência de STR para células progressivas (Progressive cell: STR) & $60 \%$ \\
Referência de VAP para células lentas (Slow cells: VAP Cut-off) & $20,0 \mu \mathrm{m} / \mathrm{s}$ \\
Referência de VSL para células lentas (Slow cells: VSL Cut-oft) & $20,0 \mu \mathrm{m} / \mathrm{s}$ \\
Limite superior de tamanho da célula (Qc plots: Static size gates-Max) & 1,51 pixels \\
Limite inferior do tamanho da célula (Qc plots: Static size gates-Min) & 0,32 pixels \\
Limite superior de intensidade da célula (Qc plots: Static intensity gates-Max & 1,19 \\
Limite inferior da intensidade da célula (Qc plots: Static intensity gates-Min) & 0,24 \\
Limite superior de alongamento da célula (Qc plots: Cell elongation-Max) & $98 \%$ \\
Limite inferior de alongamento da célula (Qc plots: Cell elongation-Min) & $0 \%$ \\
Aumento (optics: Magnification) & 1,89 \\
Temperatura (Stage: Set stage temperature) & $37^{\circ} \mathrm{C}$
\end{tabular}

(Fonte: Hamilton Thorne Biociences, 2005) 


\section{ANEXO C}

\section{DILUICÕES E PREPARO DAS SONDAS FLUORESCENTES}

1. IODETO DE PROPÍDIO (PI, Sigma-Aldrich, cod. P4170 - 25 mg)

- SOLUÇÃO ESTOQUE $(25 \mathrm{mg} / \mathrm{mL})$

- $25 \mathrm{mg}$ de PI + $1 \mathrm{~mL}$ de DMSO

- Armazenar em freezer $\left(-20^{\circ} \mathrm{C}\right)$, no escuro.

* Obs: DMSO - (Sigma-Aldrich, Cod. D.4540-100 mL)

- $\operatorname{SOLUÇÃO~TRABALHO~}(0,5 \mathrm{mg} / \mathrm{mL})$

- $20 \mu \mathrm{L}$ da solução estoque de IP $(25 \mathrm{mg} / \mathrm{mL})+980 \mu \mathrm{L}$ de DPBS

- Armazenar em freezer $\left(-20^{\circ} \mathrm{C}\right)$, no escuro.

2. FITC-PSA (FITC-PSA, Sigma, cod. L-0770 - 2mg)

- SOLUÇÃO TRABALHO $(100 \mu \mathrm{g} / \mathrm{mL})$

- $2 \mathrm{mg}$ de FITC-PSA + $20 \mathrm{~mL}$ de DPBS

- Aliquotar $(10 \mu \mathrm{L})$ e Armazenar a $4^{\circ} \mathrm{C}$, no escuro

3. HOECHST 33342 (Molecular Probes, cod. H-1399 - 100mg)

- SOLUÇÃO ESTOQUE (DMSO) - $(25 \mathrm{mg} / \mathrm{mL})$

- $100 \mathrm{mg}$ de $\mathrm{H} 342+4 \mathrm{~mL}$ de DMSO

- SOLUÇÃO TRABALHO (DPBS) - - 5 mg/mL) 
- $\quad 400 \mu \mathrm{L}$ da solução estoque $100 \mathrm{mg}(25 \mathrm{mg} / \mathrm{mL})+1600 \mu \mathrm{L}$ de DPBS

- Aliquotar em $10 \mu \mathrm{L}$ e armazenar em freezer $\left(-20^{\circ} \mathrm{C}\right)$, no escuro.

4. C11-BODIPY ${ }^{581 / 591}$ (MolecularProbes, cod. D3861 - 1 mg)

$* \mathrm{PM}=504,43$ (Peso Molecular)

- SOLUÇÃO TRABALHO (DMSO) - 2 mM

- $1 \mathrm{mg}$ de C11-BODIPY ${ }^{581 / 591}+1 \mathrm{~mL}$ de DMSO

- Aliquotar em microtubos com $10 \mu \mathrm{L}$ (20 análises) e vedar com Parafilm ${ }^{\circledR}$.

- Armazenar em freezer $\left(-20^{\circ} \mathrm{C}\right)$, no escuro.

- Indutor de peroxidação (compensação do C11-BODIPY na citometria)

- Solução a $64 \mathrm{mM}$ de sulfato ferroso (17,79 mg de $\left.\mathrm{FeSO}_{4} \mathrm{em} 1 \mathrm{~mL}\right)$

- Adicionar $5 \mu \mathrm{L}$ da solução de sulfato ferroso em $495 \mu \mathrm{L}$ da amostra (na concentação de $5 \times 10^{6} \mathrm{sptz} / \mathrm{mL}$ ). Incubar por $10 \mathrm{~min}$. Adicionar $0,5 \mu \mathrm{L}$ de BODIPY ( $2 \mathrm{mM}$ ) para atingir uma concentração final de $2 \mu \mathrm{M}$ e incubar por 30 min a $37^{\circ} \mathrm{C}$. Retirar uma aliquota de $145 \mu \mathrm{L}$ e adicionar $2 \mu \mathrm{L}$ de $\mathrm{H} 342+3$ $\mu \mathrm{L}$ de PI incubando novamente por $10 \mathrm{~min}$. a $37^{\circ} \mathrm{C}$. Diluir a amostra com $150 \mu \mathrm{L}$ de FIV e realizar a leitura no citômetro.

5. DAF-2 DA (4,5-diaminofluorescein diacetato) Calbiochem, cod. 251505 - 1 MG

- SOLUÇÃO TRABALHO

- $1 \mathrm{mg}$ de DAF-2 + $10 \mathrm{~mL}$ de DMSO

- $\operatorname{Aliquotar}(0,5 \mu \mathrm{L})$ e Armazenar a - $20^{\circ} \mathrm{C}$, no escuro. 


\section{ANEXO D}

1- L-ARGININA (Solução de trabalho) $=10 \mathrm{mM}$ $\mathrm{PM}=174,2 \mathrm{~g}$ (Preparo de $1 \mathrm{~mL}$ de água Mili Q)

2- L-NAME (Solução de trabalho) $=1 \mathrm{mM}$

$\mathrm{PM}=269,69 \mathrm{~g} / \mathrm{mol}$ (Preparo de $1 \mathrm{~mL}$ de água Mili Q)

3- Azul de metileno (Solução de trabalho) $=100 \mathrm{mM}$ $\mathrm{PM}=319,85$ (Preparo de $1 \mathrm{~mL}$ de água Mili Q) 